\title{
Cytoskeletal and contractile structures in lens cells : biochemical, morphological and functional aspects
}

Citation for published version (APA):

Ramaekers, F. C. S. (1981). Cytoskeletal and contractile structures in lens cells : biochemical, morphological and functional aspects. [Doctoral Thesis, Maastricht University]. Reijksuniversiteit Limburg. https://doi.org/10.26481/dis.19810507fr

Document status and date:

Published: 01/01/1981

DOI:

10.26481/dis.19810507fr

Document Version:

Publisher's PDF, also known as Version of record

\section{Please check the document version of this publication:}

- A submitted manuscript is the version of the article upon submission and before peer-review. There can be important differences between the submitted version and the official published version of record.

People interested in the research are advised to contact the author for the final version of the publication, or visit the DOI to the publisher's website.

- The final author version and the galley proof are versions of the publication after peer review.

- The final published version features the final layout of the paper including the volume, issue and page numbers.

Link to publication

\footnotetext{
General rights rights.

- You may freely distribute the URL identifying the publication in the public portal. please follow below link for the End User Agreement:

www.umlib.nl/taverne-license

Take down policy

If you believe that this document breaches copyright please contact us at:

repository@maastrichtuniversity.nl

providing details and we will investigate your claim.
}

Copyright and moral rights for the publications made accessible in the public portal are retained by the authors and/or other copyright owners and it is a condition of accessing publications that users recognise and abide by the legal requirements associated with these

- Users may download and print one copy of any publication from the public portal for the purpose of private study or research.

- You may not further distribute the material or use it for any profit-making activity or commercial gain

If the publication is distributed under the terms of Article $25 \mathrm{fa}$ of the Dutch Copyright Act, indicated by the "Taverne" license above, 


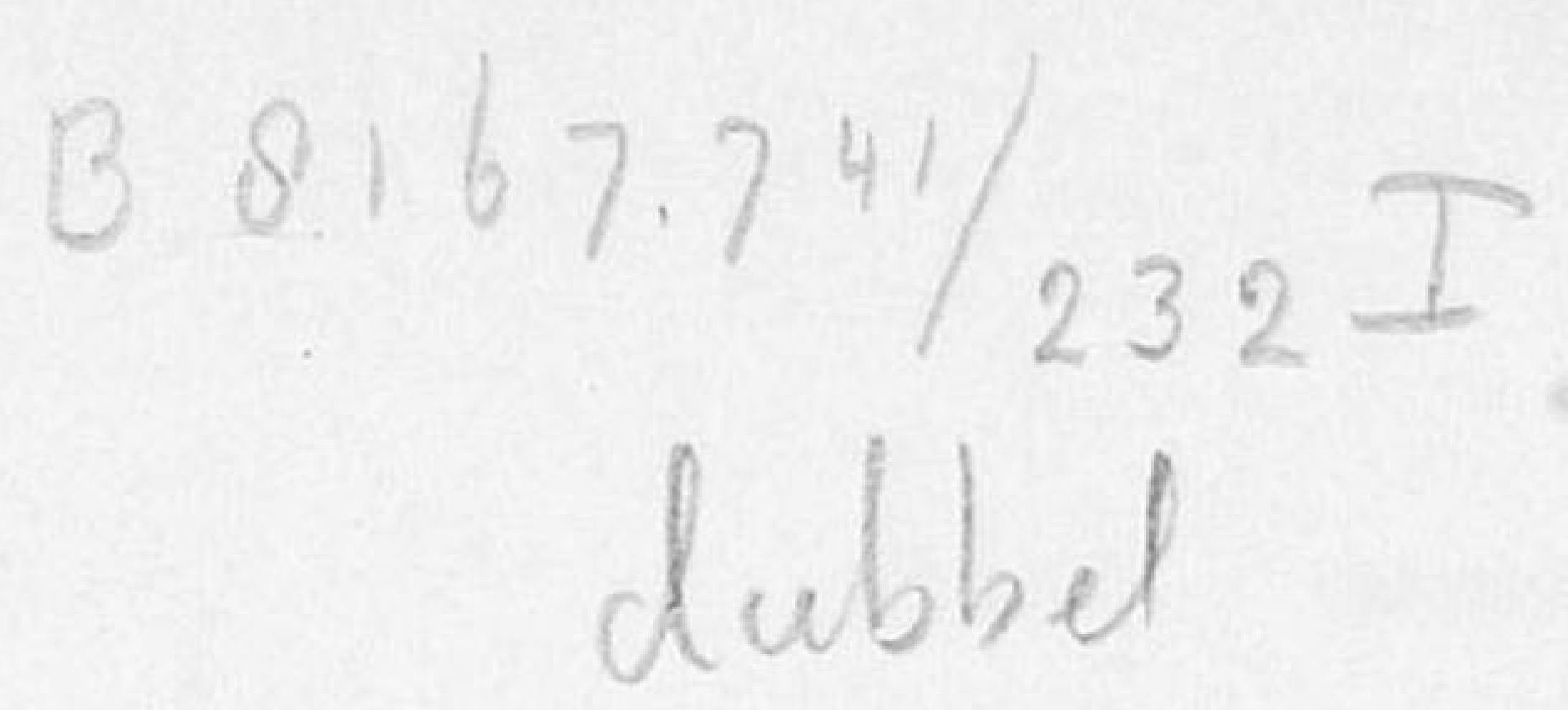

CYTOSKELETAL AND CONTRACTILE STRUCTURES IN LENS CELLS 
Promotor:

Prof.dr. H. Bloemendal

Co-promotor:

Prof.dr. E.L. Benedetti

KONINKLIJKE BIBLIOTHEEK 


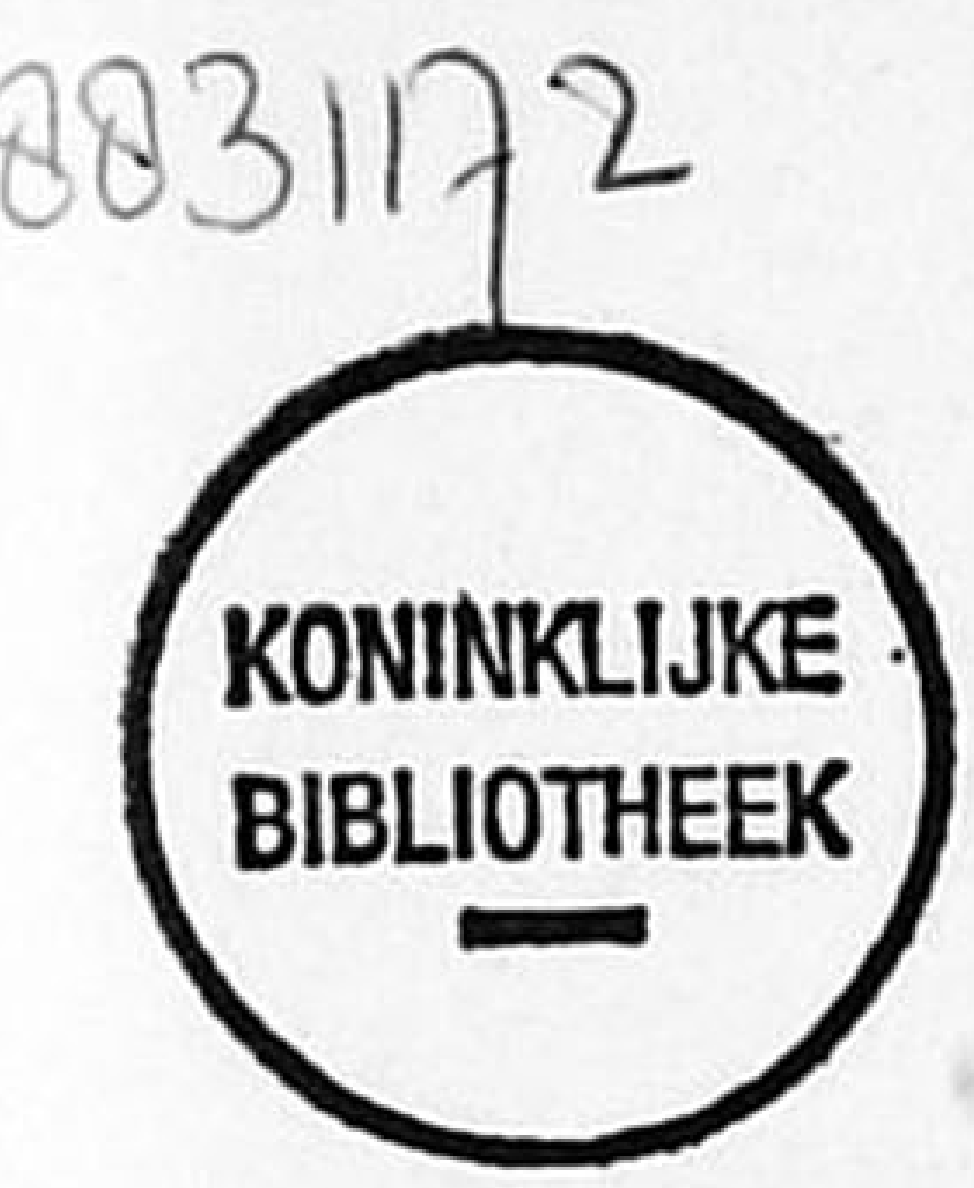

\title{
CYTOSKELETAL AND CONTRACTILE STRUCTURES IN LENS CELLS
}

\author{
BIOCHEMICAL, MORPHOLOGICAL AND \\ FUNCTIONAL ASPECTS
}

\section{PROEFSCHRIFT}

ter verkrijging van de graad van doctor in de wiskunde en natuurwetenschappen aan de Katholieke Universiteit te Nijmegen, op gezag van de Rector Magnificus

Prof. Dr. P.G.A.B. Wijdeveld volgens het besluit van het College van Decanen in het openbaar te verdedigen op donderdag 7 mei 1981 des namiddags te 4 uur door

Franciscus Charles Servatius Ramaekers geboren te Schinveld 
Een proefschrift heeft meestal maar één auteur. Toch is het werk dat erin beschreven staat dikwijls alleen mogelijk geweest door de hulp van velen. Dit geldt zeker ook voor dit proefschrift, dat o.a. tot stand is gekomen door de samenwerking met research-groepen in het buitenland.

Je remercie Dr. Irène Dunia pour son travail excellent de miscroscopie êlectronique.

I thank Or. Mary Osborn, Erika Schmid, Christine Grund, Prof.dr. Klaus Weber and Prof.dr. Werner Franke for the fruitful collaborations on the identification of the lenticular intermediate-sized filaments and for their hospitality during my visits to Göttingen and Heidelberg.

Mijn bijzondere dank gaat uit naar Annemarie Selten-Versteegen die met veel inspiratie en doorzettingsvermogen de twee-dimensionale gel electroforese-techniek heeft opgezet en toegepast en daarnaast nog tijd vond om vele parallel lopende experimenten uit te voeren.

Peter van Kan, Math Hukkelhoven, Yvonne Jeuken, Taco Boomkens, Ruud Luyten en Pieter Vorstenbosch hebben in het kader van hun doctoraalstages Biochemie essentiële bijaragen geleverd tot de resultaten van het onderzoek.

Ap Groeneveld dank ik voor de grote nauwgezetheid waarmee hij lenscelkweken heeft opgezet en verzorgd. Zonder zijn hulp zouden de hoofdstukken II, $V$ en VI niet tot stand zijn gekomen.

De stimulerende samenwerking met de collega's op de Afdeling Biochemie, maar in het bijzonder met Dr. Mac Kibbelaar, Drs. Huub Driessen en Drs. Huub Dodemont heb ik zeer op prijs gesteld.

Ik dank de Afdelingen Medische Illustratie en Medische Fotografie, het Centraal Dierenlaboratorium en de Instrumentmakerij van de Faculteit der Geneeskunde voor hun technische bijstand.

Or. Gertrude Mungyer, Or. Paul Jap, Or. Lambert Poels, Theo Hafmans, Frans van Wingaarden, Els v.d. Willart en andere medewerkers van de Afdeling Cytologie en Histologie dank ik voor hun hulp en voor de leerzame discussies, vooral met betrekking tot het lenskweek-werk.

Ik dank Angélique Brackel voor het typen van dit proefschrift, het verzorgen van de lay-out en voor de vele kopjes koffie, waarmee wij ons tijdens de laatste dagen op de been hielden. 
This investigation was carried out in part under the auspices of the Netherlands Foundation for Chemical Research (SON) and with financial aid from the Netherlands Organization for the Advancement of Science (ZWO). 
Aan allen die mij hielpen, aan mijn ouders, Tineke en Giel 
Chapter II IDENTIFICATION OF CYTOSKELETAL PROTEINS IN LENS CELLS

Chapter III LENTICULAR INTERMEDIATE-SIZED FILAMENTS. BIOSYNTHESIS AND INTERACTION WITH THE PLASMA MEMBRANE

Chapter IV CYTOSKELETAL AND CONTRACTILE STRUCTURES IN BOVINE LENS DIFFERENTIATION

Chapter V MICROFILAMENT ASSEMBLY DURING LENS CELL ELONGATION IN VITRO

Chapter VI POLYRIBOSOMES ASSOCIATED WITH MICROFILAMENTS IN CULTURED LENS CELLS

CHAPTER VII POLYRIBOSOMES ASSOCIATED WITH MICROFILAMENTS IN LENS FIBERS. IN VITRO SYNTHESIS OF THE MAJOR LENS MEMBRANE PROTEIN 


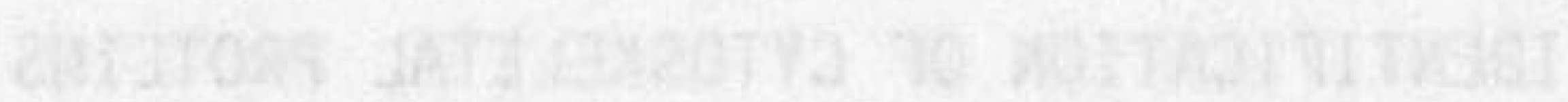


CHAPTER I

GENERAL INTRODUCTION 
CHAPTER I

\section{GENERAL INTROOUCTION}

Three types of cytoskeletal and contractile structures have been shown to occur in eukaryotic nonmuscle cells $\mathrm{s}^{1-7}$. They can be classified on the basis of their filament diameter, and by immunological and biochemical properties:

1. Microfilaments $(5 \mathrm{~nm})$, containing the two cytoplasmic forms of actin

( $\beta$ - and $\gamma$-actin) which assemble into bundles frequently called stress fibers. These latter structures may be associated with myosin, $\alpha$-actinin and tropomyosin.

2. Microtubules $(25 \mathrm{~nm})$ which consist of $\alpha$ - and $\beta$-tubulin.

3. Intermediate-sized filaments $(7-11 \mathrm{~nm})$. Although these filaments

have for a rather long time been assumed to represent a single class of cytoskeletal fibers ${ }^{8-21}$, recent investigations by Franke and cowork$e^{2} s^{22}$ have shown, mainly on the basis of immunological and biochemical data that intermediate filaments can be divided into at least five subgroups $23-26$. The subdivision could be made after the application of specific antisera in immunofluorescence studies. The following subgroups were observed:

a. Tonofilaments which are characteristic for epithelial cells and contain the prekeratin (cytokeratin) polypeptides ranging in molecular weight between 46-68 kD.

b. Intermediate-sized filaments characteristic for cells of the mesenchymal type. These filaments can be detected by using antibodies directed against a polypeptide with an approximate molecular weight of 57,000 for which the name vimentin or decamin has been proposed. They also occur in cultured cells 27 .

c. Intermediate-sized filaments characteristic for muscle tissue which can be identified with sera directed against desmin (skeletin).

d. Neurofilaments only occurring in cells of neural origin.

e. Glial filaments, which are specific to astroglia in the central nervous system ${ }^{28}$. 
Possible functions of these cytoskeletal and contractile structure in eukaryotic nonmuscle cells have been the object of many studies. It is now generally accepted that microfilaments are involved in the realization of cell shape and in cell dynamics. Processes like cell contraction and elongation, exocytosis, membrane ruffling and movement on a substrate find their molecular basis in the interaction of continuously aggregating and disaggregating microfilament bundles with the plasma membrane ${ }^{29}$. Lazarides et a ${ }^{30,31}$ showed, by using antibodies directed against $\alpha$-actinin isolated from $Z-1$ ines of muscle cells, that this protein occurs in the microfilament adhesion sites of nonmuscle cells. It was concluded that any part of the cell membrane can function as an attachment site for actin filaments ${ }^{31}$.

Although microfilament bundles (stress fibers) appear to be highly organized structures, they can disaggregate rapidly into an amorphous meshwork, mainly observed in rounded cells that do not adhere strongly to a substratum. This meshwork is commonly located just below the cell membrane and is also seen in areas of membrane ruffling in motile cells. The two states of microfilament aggregates should be considered as being in equilibrium and interconvertable. Bundles of microfilaments give the cell structural support, while the microfilaments building up the meshwork are responsible, at least partly, for cellular motility processes. Interaction of actin with a protein called profilin, has been suggested to be responsible for the regulation of microfilament polymerization ${ }^{32}$.

As a rule microtubules exist as singlets in the cytoplasm and play a role both in cell division and in the determination of cell shape. They are involved in motility processes that are either based on microtubule assembly or tubular sliding mechanisms. It has been proposed ${ }^{33}$ that microtubules are involved in cell elongation, while microfilaments are responsible for cytoplasmic contractions. The growth of axons, for example, depends on the elongation of microtubules, since the disassembiy of these filaments by mitotic drugs blocks axonal extension and promotes axonal retraction in vitro ${ }^{34-36}$. However, Dustin 6 recentiy concluded, that motion results from an interaction between actin and myosin and that microtubule poisons modify cell motility indirectly, by destroying the microtubules which maintain the general struc- 
ture and polarity of the cell.

Cytoskeletal and contractile structures in lens cells

The presence and biochemical nature of lenticular microfilaments has been documented by several investigators ${ }^{37} 46$. The criteria used are those of morphological comparison with other tissues ${ }^{41}$, immunological methods ${ }^{39}, 40$, chemical parameters ${ }^{43}$ and the heavy meromyosinreaction ${ }^{44}$. Microfilaments in lens fiber cells are covered with globular particles identified as $\alpha$-crystallin aggregates and ribosomes 47 (see also Chapter VII). An attempt has been made to correlate distribution of actin filaments in lenses of different animals to their accommodative capability 41,48 .

Further functions ascribed to these microfilaments in lens concern epithelial woundhealing ${ }^{49}$, maintenance of cell structure ${ }^{50}$ and cell elongation during differentiation ${ }^{38}$. Moreover, Mousa et al have found that disorganization of actin filaments by cytochalasin $D$ gives rise to a cortical cataract ${ }^{51}$. Myosin has been shown to occur in ocular nonmuscle tissues by Drenckhahn and Gröschel-Stewart ${ }^{40}$.

Microtubules have been shown to occur mainly in the lens epithelial cells and in the newly formed cortical fibers $39,44,45,52,53$. Piatigorsky and coworkers ${ }^{53}$ reported a function in lens differentiation for microtubules.

The nature of the lenticular intermediate-sized filaments has until now been a subject of speculation and confusion $43-46,54-58$. For chick lens Maisel et al ${ }^{54}$ show a decrease in the abundancy of the filaments in going from epithelium to the nucleus, where no intermediate-sized filaments can be observed. The protein, building up these filaments occurs in the urea-soluble fraction of the lens $46,59-61$ and was described to have a molecular weight slighly higher than those of both tubulin and desmin 62 .

In Chapter II it is shown that the protein subunit of the intermediate-sized filaments in both bovine and murine lens cells can immunologically and biochemically be identified as vimentin. Biochemical and morphological features of cytoskeletal and contractile structures in lens cells have recently been reviewed ${ }^{63,64}$. 
Aim of the present investigation

The major purpose of this study is to contribute to our understanding of the nature, interrelationship and functions of the lenticular plasma membrane-cytoskeleton complex. For this aim it is necessary to characterize various filamentous constituent in particular the intermediate-sized filaments, the microfilament associated proteins and the structures interacting with these latter fibers.

Several procedures have been used for this characterization, including immunology, electron microscopy and one- and two-dimensional gel electrophoresis (Chapter II). In subsequent chapters the following topics will be dealt with.

Chapter III describes the interaction between intermediate-sized filaments and the lens plasma membrane.

Chapters IV and V give a survey on the role of microfilaments during lens cell elongation in vitro and it possible counterpart, differentiation in vivo.

In Chapters VI and VII evidence is provided for an association between polyribosomes and the cytoplasmic matrix. 
1. Korn, E.D., Proc. Natl. Acad. Sci. USA 75 (1978) 588.

2. Clarke, M. and Spudich, J.A., Ann. Rev. Biochem. 46 (1977) 797.

3. Osborn, M., Born, T., Koitsch, H.J. and Weber, K., Cell 14 (1978) 477.

4. Lazarides, E. and Revel, J.P., Scient. Am. 240 (1979) 88.

5. Lazarides, E., Nature 283 (1980) 249.

6. Dustin, P., Microtubules, Springer Verlag Berlin (1978).

7. Goldman, R., Pollard, T. and Rosenbaum, J. (Eds.) Cell Motility Book A-C. Vol 3, Cold Spring Harbor Conferences on Cell Proliferation, Cold Spring Harbor Laboratory (1976).

8. Ishikawa, H., Bischoff, R. and Holtzer, H., J. Cell Biol. 38 (1968) 538.

9. Franke, W.W., Protoplasma 73 (1971) 263.

10. Goldman, R.D., J. Cell Biol. 51 (1971) 752.

11. Holtzer, H., Fellini, S., Rubinstein, N., Chi, J. and Strahs, K., Cell Motility (R.D. Goldman, T. Pollard and J. Rosenbaum, Eds.), p 823, Cold Spring Harbor Laboratory, Cold Spring Harbor N.Y. (1976).

12. Lazarides, E. and Hubbard, B.D., Proc. Nat1. Acad. Sci USA 73 (1976) 4344.

13. Shelanski, M.L., Yen, S.-H. and Lee, V.M., Cell Motility (R.D. Goldman, T. Pollard and J. Rosenbaum, Eds.), p 1007, Cold Spring Harbor Laboratory, Cold Spring Harbor N.Y. (1976).

14. Yen, S.-H., Dahl, D., Schachner, M. and Shelanski, M.L., Proc. Natl. Acad. Sci. USA 73 (1976) 529.

15. Blose, S.H., Shelanski, M.L. and Chacko, S., Proc. Natl. Acad. Sci. USA 74 (1977) 662.

16. Osborn, M., Franke, W.W. and Weber, K., Proc. Nat1. Acad. Sci. USA 74 (1977) 2490.

17. Starger, J.M. and Goldman, R.D., Proc. Natl. Acad. Sci. USA 74 (1977) 2422.

18. Franke, W.W., Grund, C., Osborn, M. and Weber, K., Cytobiologie 17 (1978) 365.

19. Gordon, W.E., Bushnel1, A. and Burridge, K., Cell 13 (1978) 249.

20. Hynes, R.0. and Destree, A.T., Cell 13 (1978) 151. 
21. Small, J.V. and Celis, J.E., J. Cell Sci. 31 (1978) 393.

22. Franke, W.W., Schmid, E., Weber, K. and Osborn, M., Exp. Cell Res. 118 (1979) 95.

23. Lazarides, E., Exp. Cel1 Res. 112 (1978) 265.

24. Franke, W.W., Weber, K., Osborn, M., Schmid, E. and Freudenstein, E., Exp. Cell Res. 116 (1978) 429.

25. Franke, W.W., Schmid, E., Osborn, M. and Weber, K., Proc. Natl. Acad. Sci. USA 75 (1978) 5034.

26. Davison, P.F., Hong, B.S. and Cooke, P., Exp. Cell Res. 109 (1977) 471.

27. Franke, W.W., Schmid, E., Winter, S., Osborn, M. and Weber, K., Exp. Cell Res. 123 (1979) 25.

28. Rueger, D.C., Huston, J.S., Dah1, D. and Bignami, A., J. Mol. Biol. 135 (1979) 53.

29. Cohen, C., TIBS 73 (April 1979).

30. Lazarides, E. and Burridge, K., Cell 6 (1975) 289.

31. Lazarides, E., J. Cell Biol. 68 (1976) 202.

32. Carlson, L., Nyström, L.E., Sundkvist, I., Markey, F. and Lindberg, U., J. Mol. Biol. 115 (1977) 465.

33. Burnside, B., J. Supramol. Struct. 227 (1976) 257.

34. Daniels, M.P., J. Cell Biol. 53 (1972) 164.

35. Yamada, K.M., Spooner, B.S. and Wessels, N.K., Proc. Nat1. Acad. Sci. USA 66 (1970) 1206.

36. Marchiso, P.C., Osborn, M. and Weber, K., Brain Res. 155 (1978) 229.

37. Benedetti, E.L., Dunia, I., Bentzel, C.J., Vermorken, A.J.M., Kibbelaar, M. and Bloemendal, H., Biochim. Biophys. Acta 457 (1976) 353.

38. Mousa, G.Y. and Trevithick, J.R., Develop. Biol. 60 (1977) 14.

39. Lonchampt, M.0., Laurent, M., Courtois, Y., Trenchev, P. and Hughes, R.C., Exp. Eye Res. 23 (1976) 505.

40. Drenckhahn, D. and Gröschel-Stewart, U., Cell Tiss. Res. 181 (1977) 493.

41. Rafferty, N.S. and Goossens, W., Exp. Eye Res. 26 (1978) 177.

42. Mousa, G.Y. and Trevithick, J.R., Exp. Eye Res. 29 (1979) 71. 
43. Kibbelaar, M., Selten-Versteegen, A.M.E., Dunia, I., Benedetti, E.L. and Bloemendal, H., Eur. J. Biochem. 95 (1979) 543.

44. Bradley, R.H., Ireland, M.E. and Maisel, H., Exp. Eye Res. 28 (1979) 441.

45. Bradley, R.H., Ireland, M.E. and Maisel, H., Acta Ophthalmol. 57 (1979) 461.

46. Nasser, S., Bradley, R., Alcala, J. and Maisel, H., Exp. Eye Res. 30 (1980) 109.

47. Bloemendal, H., Kibbelaar, M.A., Ramaekers, F.C.S., SeltenVersteegen, A.M.E., Dunia, I. and Benedetti, E.L. In: Prot. Biol. Fluids, Proc. 26th Colloq., Brussels (H. Peeters, Ed.). Pergamon Press 0xford (1979) 499.

48. Kibbelaar, M.A., Ramaekers, F.C.S., Ringens, P.J., SeltenVersteegen, A.M.E., Poels, L.G., Jap, P.H.K., Rossum van, A.L., Feltkamp, T.E.W. and Bloemendal, H., Nature 285 (1980) 506.

49. Rafferty, N.S., Anat. Rec. 186 (1976) 115.

50. Ramaekers, F.C.S., Hukkelhoven, M.W.A.C., Groeneveld, A. and Bloemendal, H., Ophthal. Res. 11 (1980) 283.

51. Mousa, G.Y., Creighton, M.0. and Trevithick, J.R., Exp. Eye Res. 29 (1979) 379.

52. Kuwabara, T., Arch. Ophthalmol. 79 (1968) 189.

53. Piatigorsky, J., Ann. N.Y. Acad. Sci. 253 (1975) 333.

54. Maisel, H., Alcala, J., Lieska, N. and Rafferty, N., Ophthalmic Res. 9 (1979) 147.

55. Maisel, H., Lieska, N. and Bradley, R., Experientia 34 (1978) 352.

56. Ireland, M., Maisel, H. and Bradley, R., Ophthalmic Res. 10 (1978) 231.

57. Maisel, H., Exp. Eye Res. 25 (1977) 595.

58. Maisel, H. and Perry, M.M., Exp. Eye Res. 14 (1972) 7.

59. Maisel, H. and Rasmussen, N.S., Ophthalmic Res. 10 (1978) 241.

60. Kibbelaar, M.A. and Bloemenda1, H., Exp. Eye Res. 29 (1979) 679.

61. Kibbelaar, M.A., Biochemical and ultrastructural features of the plasma membrane cytoskeleton complex in eye lens fibers (actin in the lens), Ph.D. Thesis, University of Nijmegen (1979).

62. Lo, W.R. and Maisel, H., Ophthalmic Res. 11 (1979) 129. 
63. Ramaekers, F.C.S. and Bloemendal, H. In: Molecular and Cellular Biology of the Eye Lens, Chapter 3 (H. Bloemendal, Ed.). Wiley and Sons, New York (1981) 85-136.

64. Benedetti, E.L., Dunia, I., Ramaekers, F.C.S. and Kibbelaar, M.A. In: Molecular and Cellular Biology of the Eye Lens, Chapter 4 ( $H$. Bloemendal, Ed.). Wiley and Sons, New York (1981) 137-188. 


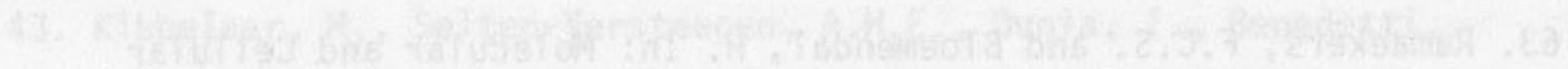

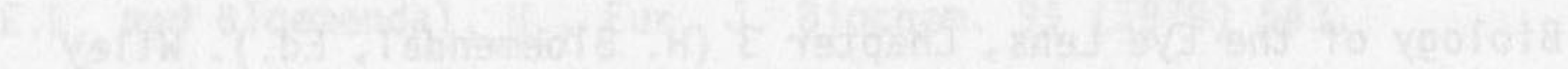

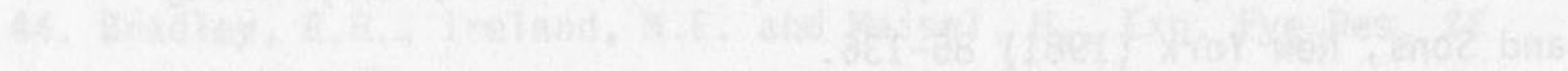

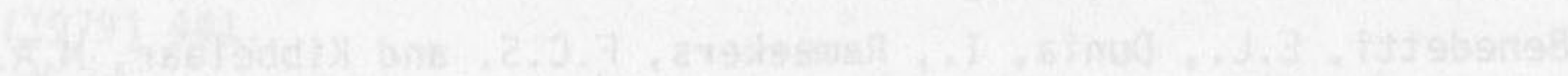

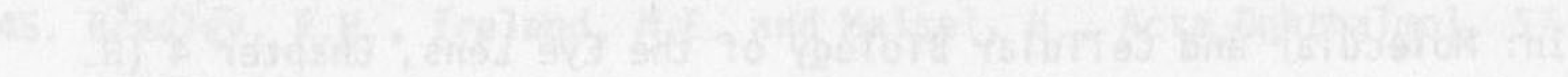

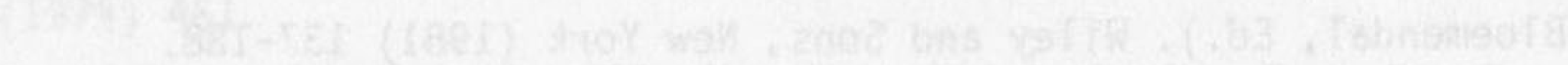
C5.

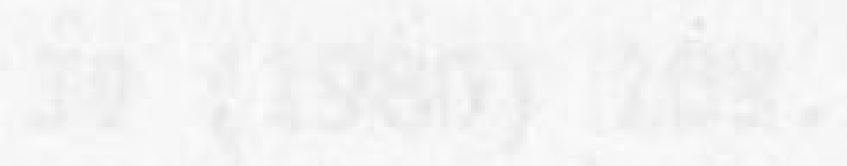

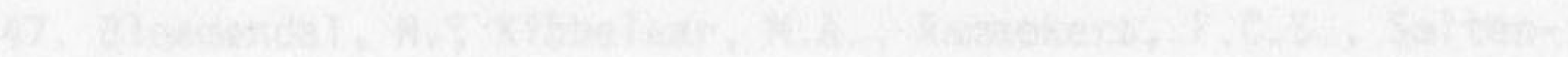

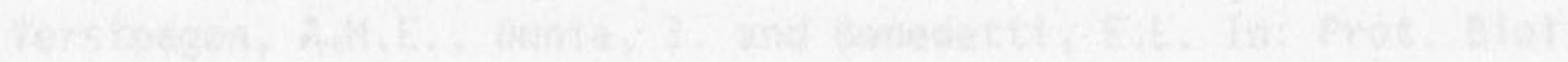

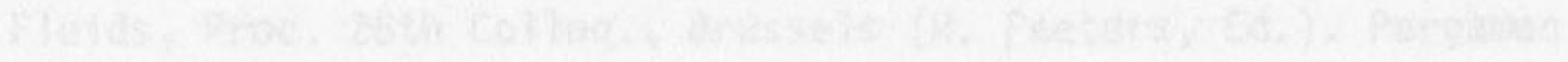

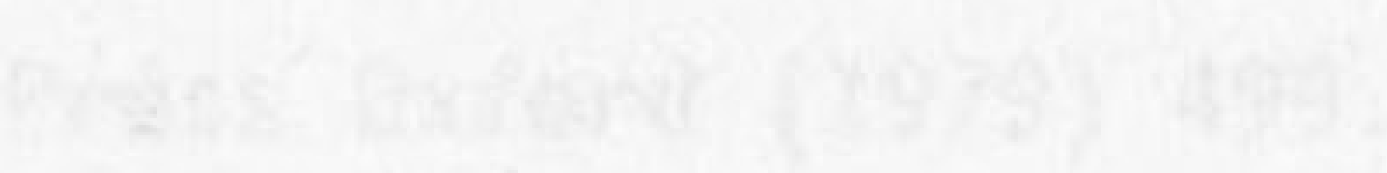

a

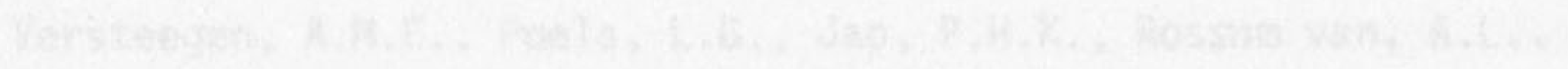

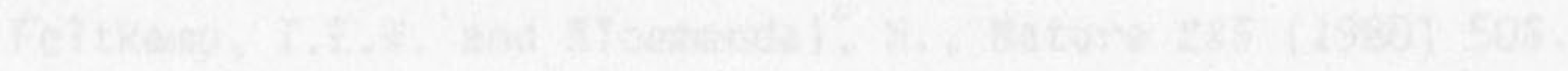

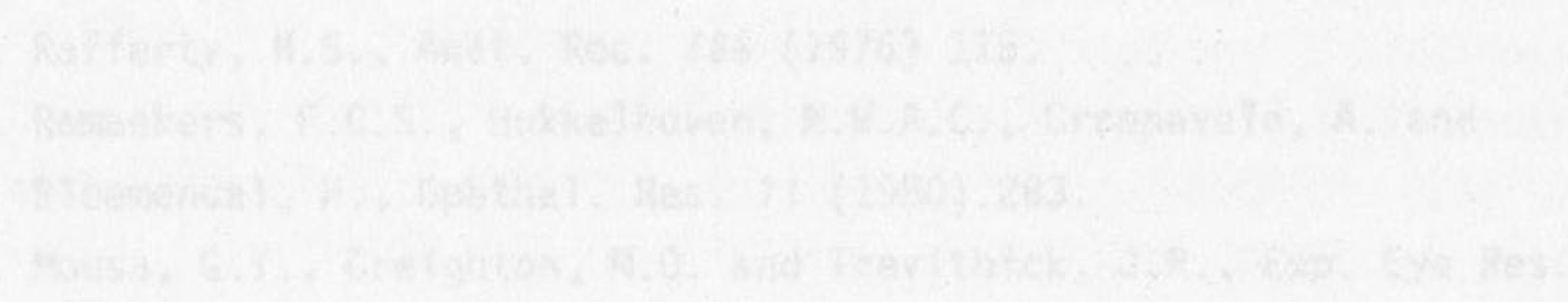


CHAPTER II

IDENTIFICATION OF THE CYTOSKELETAL PROTEINS IN LENS CELLS

The results described in this chapter have been published:

F.C.S. Ramaekers, M. Osborn, E. Schmid, K. Weber, H. Bloemendal and W.W. Franke, Exp. Cell Res. 127 (1980) 309-327. 
CHAPTER II

IDENTIFICATION OF THE CYTOSKELETAL PROTEINS IN LENS CELLS

SUMMARY

Proteins of contractile and cytoskeletal elements have been studied in bovine lens forming cells growing in culture as well as in bovine and murine lenses grown in situ by immunofluorescence microscopy using antibodies to the following proteins: actin, myosin, tropomyosin, $\alpha$-actinin, tubulin, prekeratin, vimentin and desmin. Lens forming cells contain actin, myosin, tropomyosin, and a-actinin which in cells grown in culture are enriched in typical cablelike structures, i.e. microfilament bundles. Antibodies to tubulin stain normal, predominantly radial arrays of microtubules.

In the epitheloid lens forming cells of both monolayer cultures grown in vitro and lens tissue grown in situ intermediate-sized filaments of the vimentin type are abundant whereas filaments containing prekeratinlike proteins ('cytokeratins') and desmin filaments have not been found. The absence of cytokeratin proteins observed by immunological methods is supported by gel electrophoretic analyses of cytoskeletal proteins, which show the prominence of vimentin and the absence of detectable amounts of cytokeratins and desmin. This also correlates with electron microscopic observations that typical desmosomes and tonofilament bundles are absent in lens forming cells, as opposed to a high density of vimentin filaments.

Our observations show that the epitheloid lens forming cells have normal arrays of (i) microfilament bundles containing proteins of contractile structures, (i) microtubules, and (iii) vimentin filaments, but differ from most true epithelial cells by the absence of cytokeratins, tonofilaments and typical desmosomes. The question of their relationship to other epithelial tissues is discussed in relation to lens differentiation during embryogenesis.

We conclude that the lens forming cells either represent an example of cell differentiation of nonepithelial cells to epitheloid mor- 
phology, or represent a special pathway of epithelial differentiation characterized by the absence of cytokeratin filaments and desmosomes. Thus two classes of tissues with epithelialike morphology can be distinguished: those epithelia which contain desmosomes and cytokeratin filaments and those epitheloid tissues which do not contain these structures but are rich in vimentin filaments (lens cells, germ epithelium of testis, endothelium).

\section{INTRODUCTION}

The formation of the lens and the characteristics of its cells are important objects in studies of differentiation both in embryogenesis ${ }^{1-3}$ as well as in vitro ${ }^{4-7}$.

Because of its special anatomical environment the lens offers a unique opportunity to isolate, propagate and study in vitro a homogeneous population of cells derived from the outer epitheloid layer of lens cells commonly referred to as 'lens epithelium'. The maintenance of the epitheloid character over long periods of time makes such cultures particularly interesting for studies of cell biological phenomena including in vitro aging and differentiation. Epitheloid lens forming cells, which in situ form a monolayer bordering on the frontal surface of the lens capsule and elongate at the equatorial zone of the lens to form the terminally differentiated 'lens fiber' cells, can elongate in vitro either spontaneous $1 y^{8}, 9$ or after incubation with dexamethasone $^{10}$ or retinal extracts ${ }^{11}$. Cytoskeletal elements may play a role in the differentiation into lens forming cells as well as in cell elongation since elongation can be inhibited by colchicine ${ }^{8}$, which results in disassembly of microtubules, or by cytochalasin, which causes rearrangement of microfilamentous structures ${ }^{12}$.

Cytoskeletal elements can be visualized in a large variety of nonmuscle cell types by indirect immunofluorescence microscopy using antibodies raised against specific structural proteins. Thus antibodies to actin have been used to reveal bundles of microfilaments in many cell types $^{13,14}$ which are assumed to be involved in cell locomotion and elongation. These microfilament bundles have been shown to contain ad- 
ditional proteins of the contractile apparatus of muscle such as myosin, tropomyosin and a-actinin ${ }^{13,15-17}$. Similarly antibody to tubulin can be used to reveal the display of microtubules ${ }^{18}$, and antibodies to vimentin, prekeratin or desmin allow the demonstration of arrangements of the different classes of intermediate-sized filaments ${ }^{19-26}$.

The type of intermediate-sized filaments present in specific cell types seems to depend primarily on their differentiation and embryological origin. In cells of epithelial origin, for example, usually tonofilamentlike structures stained by antibodies to epidermal prekeratin are found $20,24,26$ whereas vimentin type intermediate-sized filaments seem to be characteristic of mesenchymal or mesenchymally derived cells and of cells replicating in culture 19-22,25-29.

In a study of lens epithelial cells in vitro, Lonchampt et al 30 have documented arrangements of microfilaments, microtubules and filaments of intermediate diameters by electron microscopy; they have also shown that actin antibodies appeared to stain extended thick strands lying in the long axis of the cell. Because of our interest, on the one hand, in the lens epithelial cells as a model system for differentiation and, on the other hand, in characterizing different cell types for the classes of intermediate-sized filaments which they contain, we have studied lens epithelial cells growing in vitro and in situ by immunofluorescence techniques, by electron microscopy, and by gel electrophoresis of cytoskeletal proteins.

Our results show that the arrays of contractile and cytoskeletal structures present in cultured bovine lens cells are similar to those found in other cell types and that these cells are extremely rich in intermediate-sized filaments of the vimentin type. Somewhat surprising is our finding of the absence of filaments of the cytokeratin class, including desmosome-attached tonofilaments. This raises the question whether these cells are really epithelial in nature and allows two major types of cells of epithelialike morphology to be distinguished. 


\section{MATERIALS AND METHODS}

Tissue and cell culture

Calf eyes were obtained from the slaughterhouse and either used directly or kept on ice. Rat and mouse lenses were similarly obtained. For freeze-sectioning the lenses were directly frozen and sectioned as described elsewhere ${ }^{31}$. For electron microscopy, whole lenses or pieces of lens tissue were fixed (see below).

For cell culture the eyes were washed with distilled water and opened at the lateral side to remove the lenses. The lens capsule with adhering epithelial cells, was isolated and spread out on the bottom of plastic culture flasks ${ }^{32}$. The capsules were allowed to stick to the surface of the flask for $30 \mathrm{~min}$ at $37^{\circ} \mathrm{C}$. Then the tissue culture medium, consisting of TC $199,0.33 \%$ lactalbumin hydrolysate in Hank's solution $(1: 2 \mathrm{v} / \mathrm{v})$ with $10 \%$ newborn calf serum (Flow Laboratories, Glasgow, Scotland, U.K.), penicillin (100 I.U. per ml) and streptomycin $(100 \mu \mathrm{g} / \mathrm{ml})$ was added.

After one week, cells grew from the capsule on the surface of the flask. Cells were subcultured by treatment of the cells with $0.35 \%$ trypsin in $\mathrm{Ca}^{2+}-$ and $\mathrm{Mg}^{2+}$-free Tyrode solution. Routine transfers were done weekly at a split ratio 1:4. Colcemid when present was used at a concentration of $10^{-6} \mathrm{M}^{28}$.

\section{Antibodies and indirect immunofluorescence microscopy}

The antibody preparations used in this study have been described in detail. Native antisera as well as antibodies purified by column chromatography on their respective antigens bound to Sepharose 4B were used. Actin antibodies were raised in rabbits against denatured chicken gizzard actin ${ }^{13,33}$. For references to the antibodies raised against denatured heavy chain from gizzard myosin, and on a-actinin and tropomyosin antibodies ${ }^{14}, 33$, respectively.

Prekeratin antibodies were raised in guinea pigs against prekeratin from bovine. hoof epidermis ${ }^{24}$. Vimentin antibodies were raised in guinea pigs against the constitutive protein of 57,000 molecular weight purified from mouse 3 T3 cytoskeletons $20,28,29$ and desmin antibodies were raised in rabbits against desmin purified from chicken gizzard ${ }^{29}$. Affinity-purified antibodies were used at a concentra- 
tion of ca $50 \mu \mathrm{g} / \mathrm{ml}$.

For localization of procollagen synthesis a rabbit antiserum specifically directed against the carboxyl polypeptide of type I procollagen from chick was used that cross-reacted with mammalian procollagen I but not with collagens I and IV (this antiserum was a generous gift from Dr B.R. 01sen, Dept of Biochemistry, Rutgers University Medical School, Piscataway, N.J., USA).

FITC labelled goat-anti-rabbit $\gamma$-globulins, and FITC labelled rabbit-anti-guinea pig $\gamma$-globulins were from Miles-Yeda (Israel).

For immunofluorescence microscopy cells were seeded onto $12 \mathrm{~mm}$ glass coverslips. Fixation was in $-10^{\circ} \mathrm{C}$ methanol for $6 \mathrm{~min}$, except for the localization of procollagen I where cells were fixed in ethanol/ methanol $(1: 1, v / v)$ for 10 min. After a brief rinse in phosphate buffer saline (PBS) the first antibody was added for 45 min at $37^{\circ} \mathrm{C}$. After washing in PBS, the FITC labelled second antibody was added, and the coverslips incubated for a further 30 min at $37^{\circ} \mathrm{C}$. The coverslips were then mounted in Moviol 4-88, and observed in a Zeiss photomicroscope (Carl Zeiss, Oberkochen, Fed. Rep. of Germany; for further details of the immunofluorescent procedures ${ }^{14}, 34$. The procedures used for immunofluorescence microscopy on frozen sections have been described $31-35,37$.

\section{Electron microscopy}

Electron microscopy of bovine lens cells grown on cover slips was performed as described for other cells $\mathrm{s}^{38}$. Lens tissue was fixed and processed as described for other tissues ${ }^{39}$.

\section{Labelling of lens cell proteins and preparations of cell lysates}

Confluent monolayers of bovine lens epithelial cells, growing in plastic tissue culture flasks $\left(200 \mathrm{~cm}^{2}\right)$ were incubated for $16-20 \mathrm{hrs}$ with $5 \mu \mathrm{Ci} / \mathrm{ml}$ medium of $\mathrm{L}-[35 \mathrm{~S}]$-methionine (Radiochemical Centre, Amersham, England) in medium lacking methionine.

After incubation the medium was removed and the cells rinsed twice with Tyrode buffer. Then the cells were harvested with a rubber policeman, centrifuged at low speed and washed with Tyrode buffer. The cells were lysed with a Dounce-Potter homogenizer in TKM buffer (50 mM 


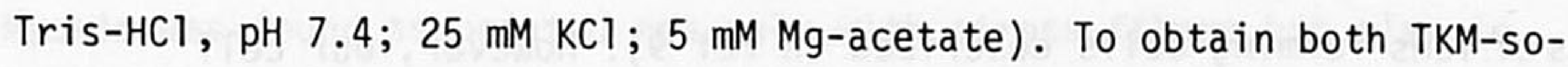
luble and TKM-insoluble protein fractions, the lysates were centrifuged at $10,000 \times \mathrm{g}$ and the resulting pellet washed three times in TKM buffer. For analysis of the proteins by gel electrophoresis, fractions were used either after lyophilization or after TCA precipitation. A1ternatively, cytoskeletons were prepared by treatment of cells with high salt buffers and Triton $X-100$ solutions as described ${ }^{24,40}$.

\section{Gel electrophoresis}

Protein analysis was performed by one-dimensional sodium dodecyl sulfate-polyacrylamide gel electrophoresis as described ${ }^{28,29}$ and by two-dimensional gel electrophoresis, using isoelectric focusing in the first dimension, according to $0^{\prime} F a r r e 11^{41}$. Radioactive bands were visualized by scintillation autoradiography ${ }^{42}$, in combination with the drying procedure described by Berns and Bloemenda $7^{43}$.

Standards for gel electrophoresis included $\alpha$-actin purified from heart muscle, $\beta$ - and $\gamma$-actins purified from bovine brain (courtesy $\mathrm{Dr} J$. Vandekerckhove), tubul in purified from rat brain (courtesy $\mathrm{Dr}$ I. Sandoval), vimentin from mouse 3 Т 3 cells and human fibroblasts $20,28,29$, prekeratin from bovine hoof epidermis ${ }^{24}$ and snout desmosome-attached tonofilaments ${ }^{44}$, and desmin from chick gizzard and porcine uterus smooth muscle ${ }^{29}$.

\section{RESULTS}

General features of bovine lens cells grown in culture

Cultures derived from the monolayer of lens forming cells attached to the lens capsule have been described by several groups ${ }^{8-12,32,45-47}$. Under the culture conditions used in the present study the cells formed monolayers and maintained a polygonal epitheloid shape, at least up to passage 15 . Thereafter, an increasing percentage of cells tended to elongate and the division rate gradually decreased. Usually cell cultures did not grow for more than 40-45 passages (for bovine lens cell cultures of unlimited growth potential and properties characteristic of transformed cells ${ }^{48}$ ). In the cultures used $\alpha$ - and $\gamma-$ crystallins could no longer be detected ${ }^{32,47}$ (see, however, the cul- 
tures of lens forming cells described in ref 9). However, our cell cultures continually produced procollagen type I (result not shown) and seemed to secrete collagen type I, apparently in addition to type IV collagen described in similar cultures of bovine lens forming cells by Laurent et $a \ell^{46}$.

Production of type I procollagen and collagen in these cells is remarkable since this collagen type is not formed in cells of intact lenses as shown by immunofluorescence microscopy in adult mammals (these authors, unpublished) and in chick embryos in later stages of development 49 . The cells also produced and secreted a protein resembling fibronectin in its molecular weight and preparative behavior.

Localization of actin and other microfilament-associated proteins

Actin as well as microfilaments have been described in fractions from eye lenses $50-52$. Bovine lens forming cells growing in culture contained large amounts of actin (gel electrophoretic data, not shown here; cf Figs 3 and 4 ; cf 30).

A prominent feature of the actin arrangement concerns the extended arrays of stress fibers which can be viewed in these 30 and other ${ }^{13,33}$ cells using antibodies to actin in immunofluorescence microscopy (Fig la,b). The arrangement of the microfilament bundles depended somewhat on how long the cells had been cultured. In cells which had been transferred up to 20 times, a rather random pattern of microfilament bundles was seen. In cells at higher passage numbers (e.g. Fig la) which were more elongated in shape, parallel arrays of stress fibers were more frequent and often ran the whole length of the cell.

Occasionally, and particularly in cells of early passage numbers, cells with polygonal nets ('geodesic domes') were observed (Fig 1b) which were similar to those described in other cells grown in culture ${ }^{16,34}$. In electron micrographs of lens cells these network arrays could be shown to consist of focally centered microfilament bundles (data not shown here) similar to the 'star-like arrangements' described in lens ${ }^{30}$ and in other epitheloid cell cultures ${ }^{34}$.

Antibodies directed against myosin (Fig 1c), a-actinin (Fig 1d), and tropomyosin (not shown) also decorated the stress fibrils, indicating that these proteins form part of the microfilament bundles. 
Myosin was found associated not only with stress fibers but also in discretely stainable small units within the cytoplasm (Fig 1c; c6 53).
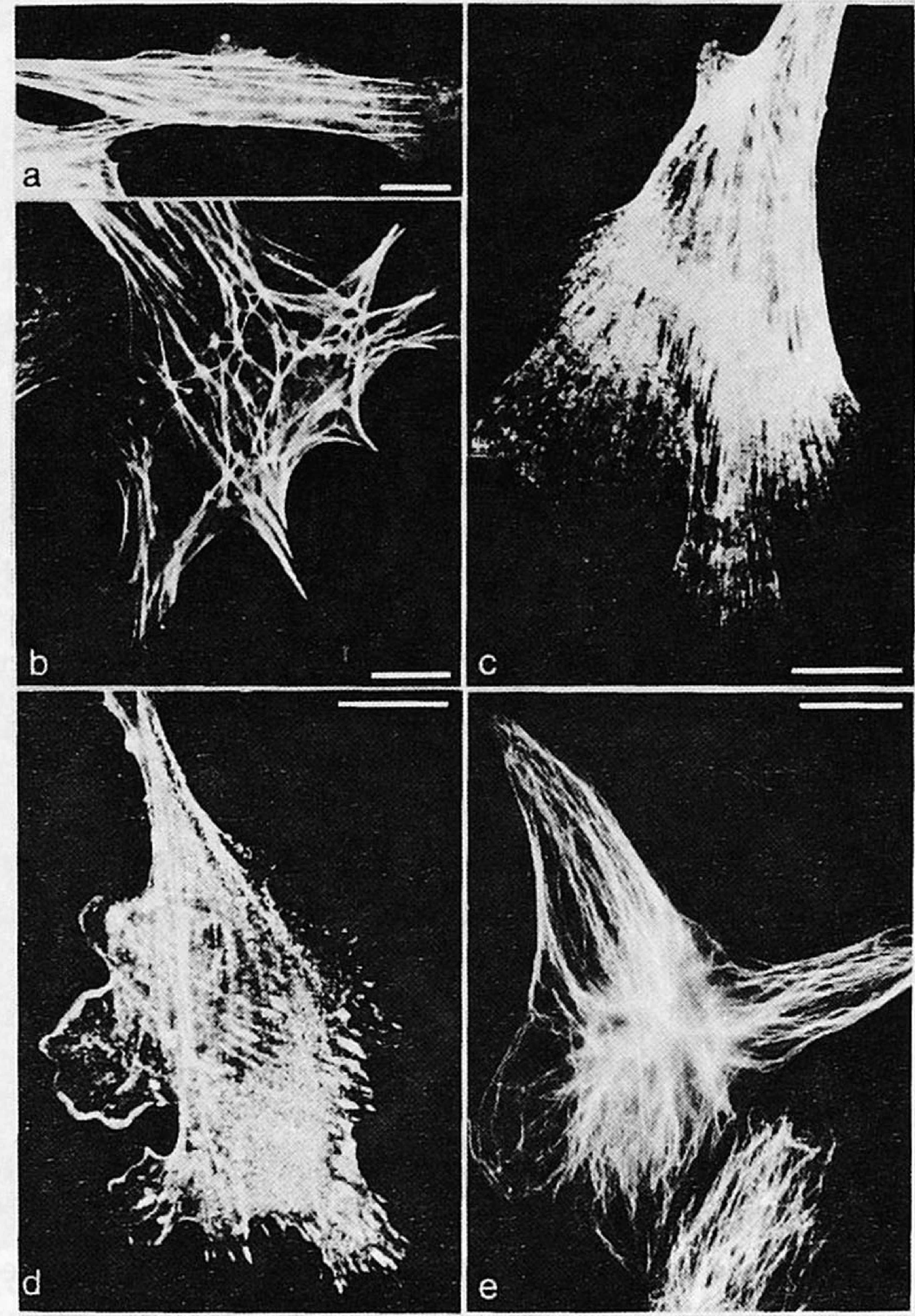

Fig 1 Cultured bovine eye lens cells stained with antibodies against actin (a, b), myosin (c), a-actinin (d) and tubulin (e) in indirect immunofluōrescence microscopy. Note staining by actin antibodies in 'stress fibers' (a) and 'geodesic dome'-like meshwork (b) $)$. Antibodies to myosin (c) and $\alpha$-actinin also decorate stress fibers often in a periodically interrupted pattern. Tubulin antibodies stain microtubules, most of which are somewhat radically arranged (e) . Bars indicate $20 \mu \mathrm{m}$. 
The $\alpha$-actinin often appeared periodically associated with the microfilament bundles as judged by the striated fluorescence (Fig 1c, d). A closer examination of the $\alpha$-actinin fluorescence also revealed decoration of 'ruffles' as well as some patched fluorescence close to the cell membrane.

Localization of tubulin in cultured lens cells

Affinity purified antibodies against bovine brain tubulin gave a positive staining in our cells. The fluorescence micrographs obtained (Fig le) showed a display of microtubules similar to those normally seen in other cell types in culture ${ }^{14,18}$ but appeared significantly different from the thick longitudinally oriented, almost stress fiberlike arrays reported to be stained by tubulin antibodies in cultured bovine lens cells by Lonchampt et $a \ell^{30}$. Fibril staining by the tubulin antibodies was abolished after treatment of the cells with colcemid.

Localization of proteins of intermediate-sized filaments in cultured lens cells

In order to establish the type of intermediate-sized filaments present in lens cells antibodies against vimentin, desmin and prekeratin were used. Of the antibodies tested only that directed against vimentin showed positive fibril staining (Fig 2a).

Strong vimentin fluorescence localized in extended fiber arrays was seen in all cells. Upon treatment with colcemid the vimentin filaments were aggregated into one large juxtanuclear, strongly stained mass (Fig 2b). The cells were not significantly stained by antibodies to desmin and by antibodies directed against prekeratin (Fig $2 c, d$ ). The same result was obtained with lens cells at early and late passages (from passage 1 to passage 39 ) as well as on cells still adhering to the lens capsule which also showed strong staining with antibodies directed against bovine lens $\alpha$-crystallin.

Thus we conclude that intermediate-sized filaments present in lens cells are exclusively of the vimentin type and that these cells do not contain filaments of the cytokeratin type, although cytokeratin-type 
intermediate filaments are typically observed in cells of epithelial origin.


Fig 2 Cultured bovine lens cells, normally grown (a) and colcemidtreated (b), in immunofluorescence microscopy using antibodies to protein subunits of intermediate-sized filaments. a and $\underline{b}$, vimentin antibodies; $c$, antibodies to bovine hoof prekeratin; $\underline{d}$, antibodies to chick gizzard desmin. Positive staining is only seen with antibodies to vimentin. Note the abundance of vimentin filaments in (a) and the formation of perinuclear aggregates of vimentin filaments after treatment of the cells with colcemid (b) . Arrowheads in $\underline{c}$ and $\underline{d}$ mark cell contours. Bars denote $20 \mu \mathrm{m}$. 
Analys is of cytoskeletal proteins from cultured lens cells

Whole cells and TKM-insoluble fractions were characterized by the predominance of actin and vimentin (data not shown).

Cytoskeletal preparations made by extraction of cultured bovine lens cells in buffers containing high salt concentrations and Triton $X-100$ were found by electron microscopy to consist primarily of intermediatesized filaments and some tangles of microfilamentous structures, similar to the appearance of such preparations made from diverse other cultured cells $\mathrm{s}^{27,40}$ and to the intermediate-sized filaments described in the 'water-insoluble fraction' of lens homogenates $50,52,54-57$.

Examination of such preparations on SDS-polyacrylamide gel electrophoresis (Fig 4) showed the predominance of a polypeptide of an apparent molecular weight of 57,000 that comigrated with murine and human vimentin, and also some residual actin (for the occurrence of actin tenaciously associated with intermediate filament material and not extracted therefrom in high salt buffers see also $19,24,27,29,40$, 58).

In addition, some minor high molecular weight polypeptide bands with mobilities similar to those of fibronectin and collagen I were sometimes noted (Fig 3; for related observations in similar cytoskeletal preparations from other cultured cells see $24,27,29,40,59)$. Polypeptides comigrating with avian and mammalian desmin and with any of the known polypeptides of authentic epidermal and tonofilamentous prekeratin were not seen on gel electrophoresis of the proteins of cytoskeletons of cultured bovine lens cells (Fig 3 ).

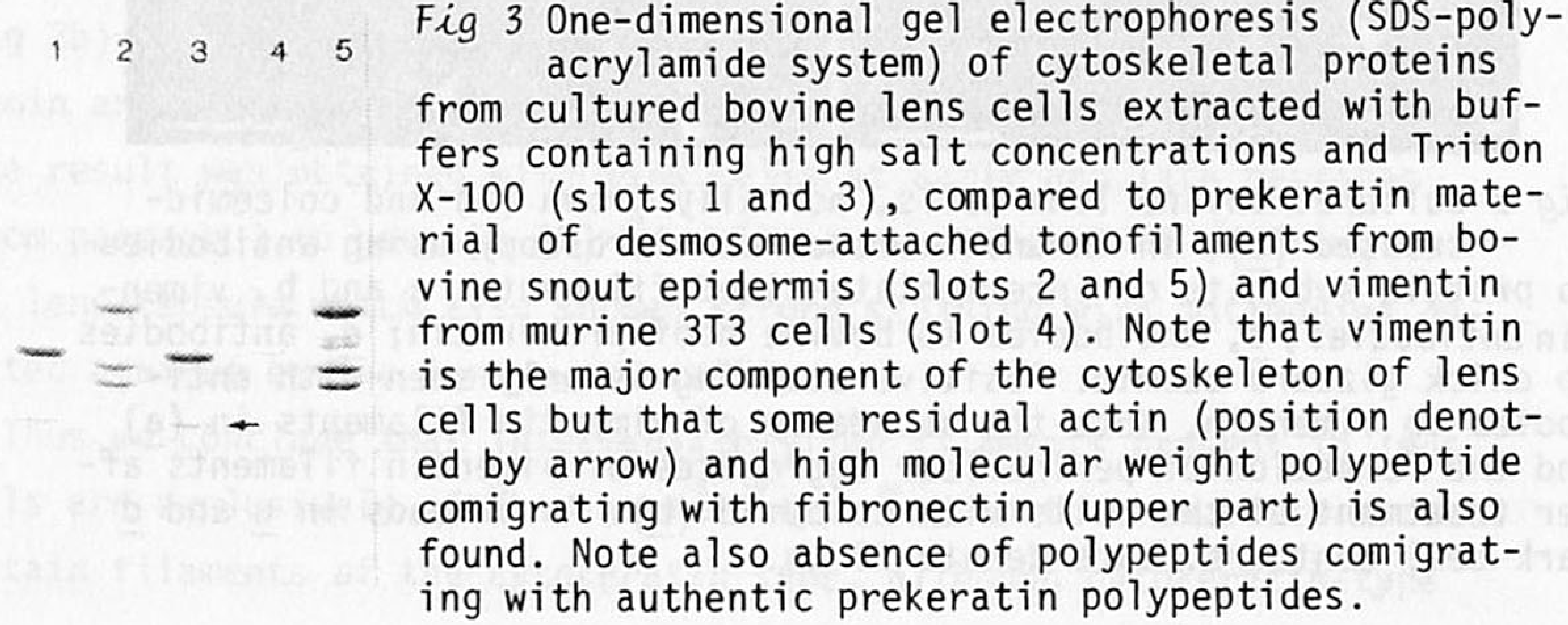


When the proteins of such cytoskeletal preparations were examined by two-dimensional gel electrophoresis again the only major protein identified as an intermediate-sized filament component was vimentin (Fig 4) which had an apparent isoelectric pH of 5.5 in the isoelectric focusing system used and showed the presence of a minor slightly more acidic isoelectric variant 60,61 . Actin not extracted during the high salt treatment was the second most frequent protein and was exclusively of the $\beta$ - and $\gamma$-type.

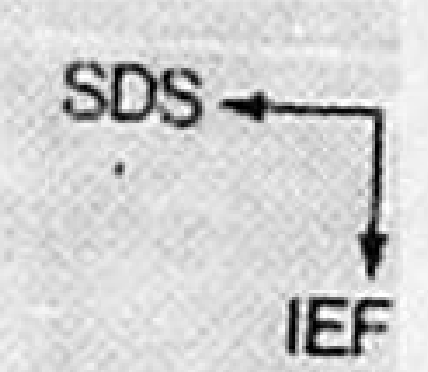

A

Fig 4 Two-dimensional gel electrophoresis of cytoskeletal proteins from high salt- and detergent-extracted cultured bovine lens cells showing the predominance of vimentin (V) and actin (A). Arrows indicate directions of isoelectric focusing (IEF) and, in the second dimension, electrophoresis after denaturation with SDS.

Electron microscopy of lens forming cells grown in culture

Some ultrastructural aspects of bovine lens cells grown in vitro have been described in the electron microscopic work of previous authors $^{8}, 30,46$.

Therefore we confine the present description to the characteristic arrangements of intermediate-sized filaments and the intercellular junctions present in these cells. Survey micrographs of sections parallel or slightly oblique to the substratum illustrated the abundance of all three filamentous elements: (i) microfilaments, mostly arranged in massive cable-like bundles; (ii) microtubules, mostly running as individual tubules in diverse directions but displaying some focal and radial orientation in the pericentriolar region (not shown here); and (iii) intermediate-sized (7-11 nm) filaments occurring as individual filaments running in all directions as well as in relatively loosely packed bundles. The high density and various forms of display of intermediate-sized filaments present in these cells are shown in Fig 5.

In certain regions of the cytoplasm the intermediate-sized filaments of the vimentin-type seemed to be the most frequent structure present (Fig 5a). With an unusually high frequency we noted in these cells 


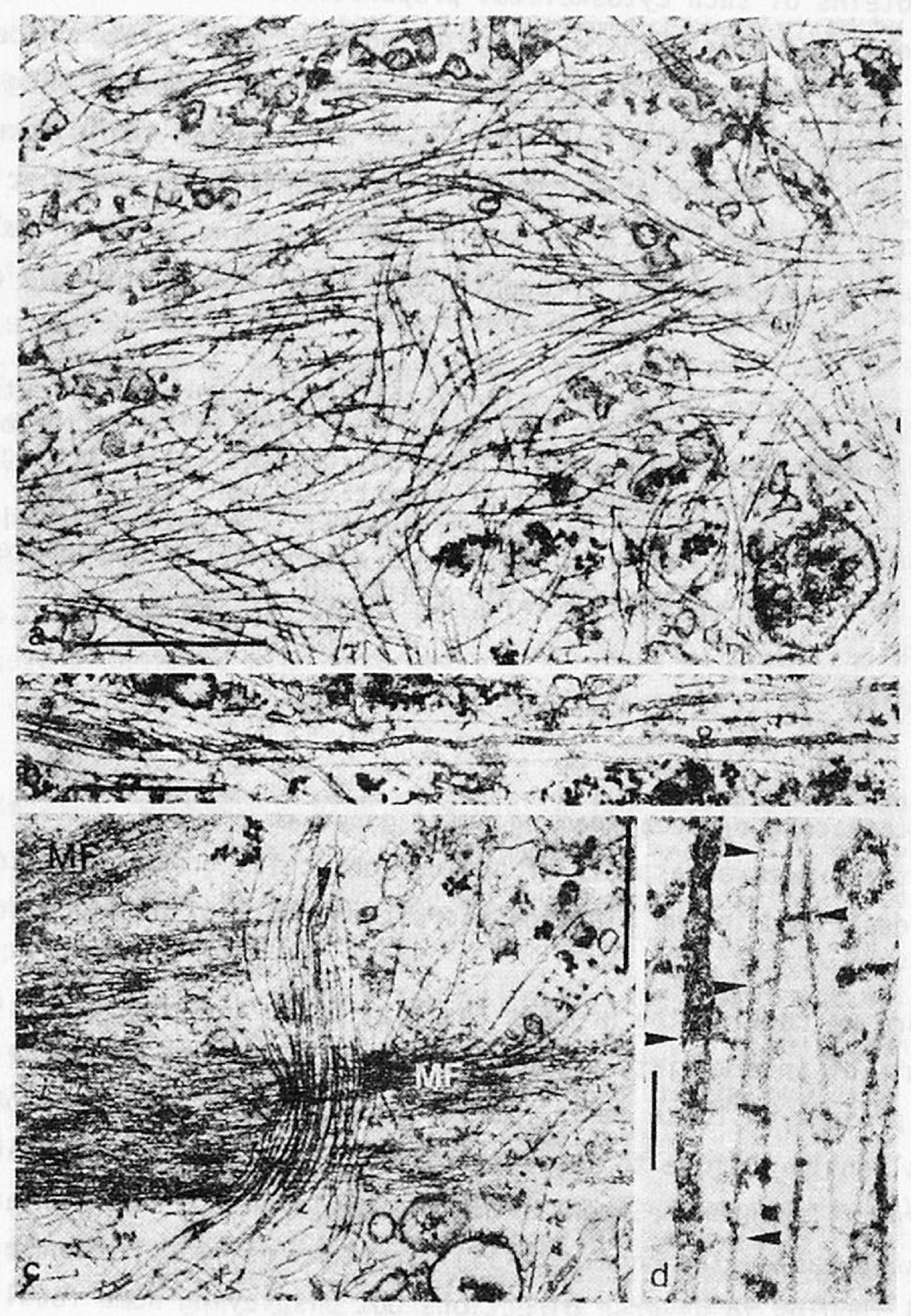

Fig 5 Electron microscopic details of organization of intermediatesized filaments of the vimentin type in cultured bovine lens cells, showing the high density of such filaments and their apparent irregular display $(\underline{a})$, extended parallel alignments with individual microtubules (b), groups of parallel microtubules (arrowhead) and intermediate filaments running perpendicularly to microfilament (MF) bundles (c; for similar observations in fibroblasts see ref 73), and lateral bridges between individual vimentin filaments and between microtubules and vimentin filaments ( $\mathrm{d}$; some are denoted by arrowheads). Bars denote $0.5 \mu \mathrm{m}(\underline{a}-\underline{c})$ and $\overline{0} .1 \mu \mathrm{m}(\underline{\mathrm{d}})$. 
parallel alignments of individual microtubules and intermediate-sized filaments that seemed to be maintained by short lateral linker structures of 2-5 $\mathrm{nm}$ width and lengths ranging from 10 to $30 \mathrm{~nm}$ (Figs $5 \mathrm{~b}-\mathrm{d}$; c6 38,62 ).

Bundles of intermediate-sized filaments, in which microtubules were sometimes included, were often seen running almost perpendicularly to the microfilament bundles (e.g. Fig $5 c$ ).

As has been shown in many other cultured cells, prolonged treatment of the bovine lens forming cells with anti-microtubular drugs such as colcemid resulted in the disappearance of microtubules, concomitantly with the disappearance of fibrillar staining by tubulin antibodies, and the formation of perinuclear aggregates of vimentin filaments that seemed to contain all cellular vimentin identifiable by immuno-cytochemical techniques ${ }^{19-22,23,31,59}$ ).

The epitheloid lens forming cells grown in vitro as monolayer sheets are connected by gap junctions and a special type of junction that resembled the fascia adhaerens type of junctions ${ }^{63}$. This special form of junction which has been described in various cells in culture ${ }^{64}$ was by far the most predominant one and, in some groups of cells, occupied more than half of the total cell-to-cell boundary encountered (Fig 6 ). Such junctions were often closely spaced and exhibited terracelike arrangements (e.g. Fig 6 ).

Typical desmosomes with pronounced midline structure, desmosomal plaques and tonofilament insertions were not observed in the lens forming cells. Intermediate-sized filaments were seen in close proximity to the intercellular boundary but appeared to be arranged at random and were never organized in tonofibrillike bundles attached to the junctions (Fig 6 ). On the contrary, the prevailing junctions, i.e. the fascia adhaerens-like, ones, were seen to represent terminal anchorage sites of microfilament bundles, and a densely stained web of fine interfilamentous material appeared at the sites of membrane anchorage (Figs 6 and $\cdot 7$ ). Only very rarely in some cells of low passage numbers were 'dotted' midlinelike structures observed in such microfilament bundle-attached junctions (Fig 7 ).

When present these junctions were seen at the ends of deep invaginations of adjacent cells with extensively interdigitated bounderies (Fig 7 ). 


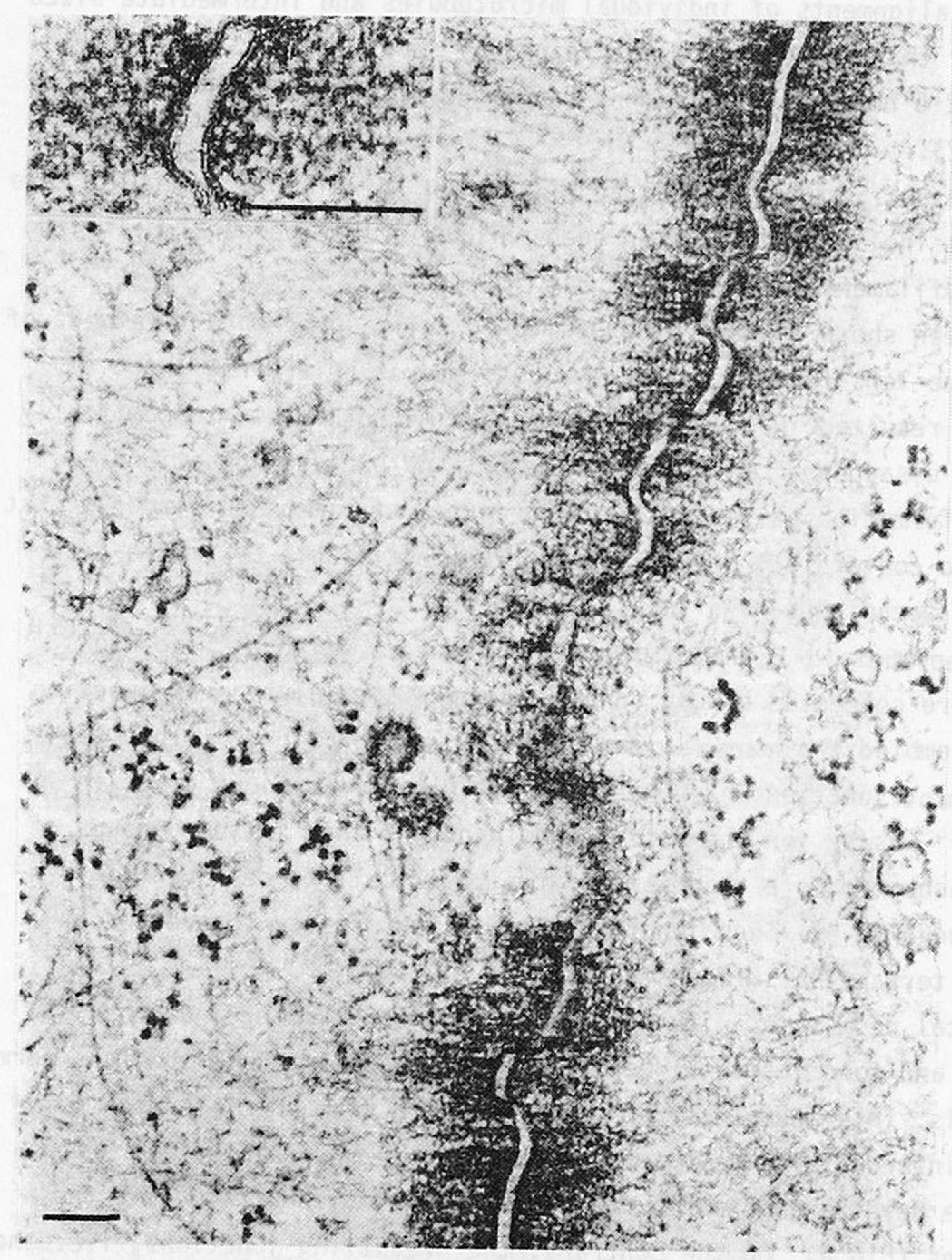

Fig 6 Survey electron micrograph showing the most frequent type of intercellular junction found in cultured bovine lens cells (passage 36). Note that intermediate-sized filaments occur in the cell periphery, in close vicinity to the junctions, but apparently are not attached to them. In contrast, bundles of filaments of microfilamentlike diameters are terminally attached to junctions of this type. Closer examination of these junctions (for higher magnification see insert) shows that the membranes are separated by a relatively wide (16-22 $\mathrm{nm}$ ) intercellular cleft, without a distinct midline structure, and are not associated with dense cytoplasmic coat structures resembling desmosomal plaques. Bars denote $0.1 \mu \mathrm{m}$. 


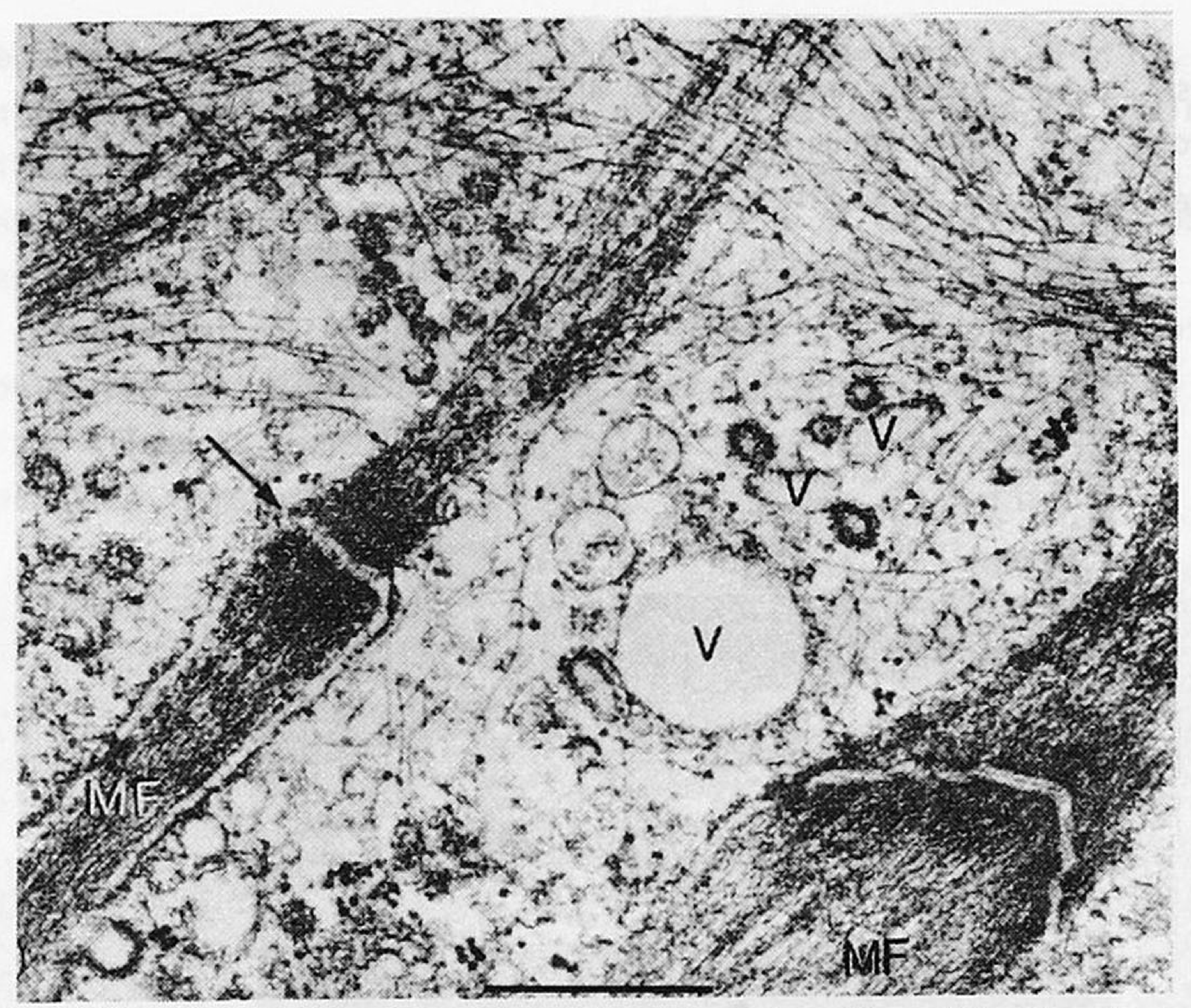

Fig 7 Electron micrograph of section through cultured bovine lens cells, in an earlier passage, showing a somewhat different type of junction of puncta adhaerens-like morphology and with 'dotted' midline structure (arrow). Note again that these junctions, which are located at the ends of cell interdigitations, are terminal attachment sites of bundles of microfilaments (MF) but not of the intermediate-sized filaments which are also abundant in this cell region (see top part of Figure). Note also numerous coated vesicles as well as variously-sized smooth surfaced vesicles (V). Bar, $0.5 \mu \mathrm{m}$.

Localization of cytoskeletal proteins and structures in lenses grown in situ

Gel electrophoretic analysis of proteins of lenses from various vertebrates as well as of subfractions have shown that this tissue contains substantial amounts of actin, which at least in part is contained in microfilaments and intermediate-sized filaments ${ }^{30,50-52,54-57,65}$.

Gel electrophoretic studies in our laboratory show that most, if not all, of the intermediate-sized filament protein is vimentin and we have not found any protein co-migrating with avian and mammalian desmin.

Immunofluorescence microscopy on frozen sections of bovine and mur- 
ine lenses showed strong reaction with antibodies to vimentin in the epitheloid cell layer bordering on the capsule and, to a significantly lesser degree, in lens fiber cells (Fig 8a-c).

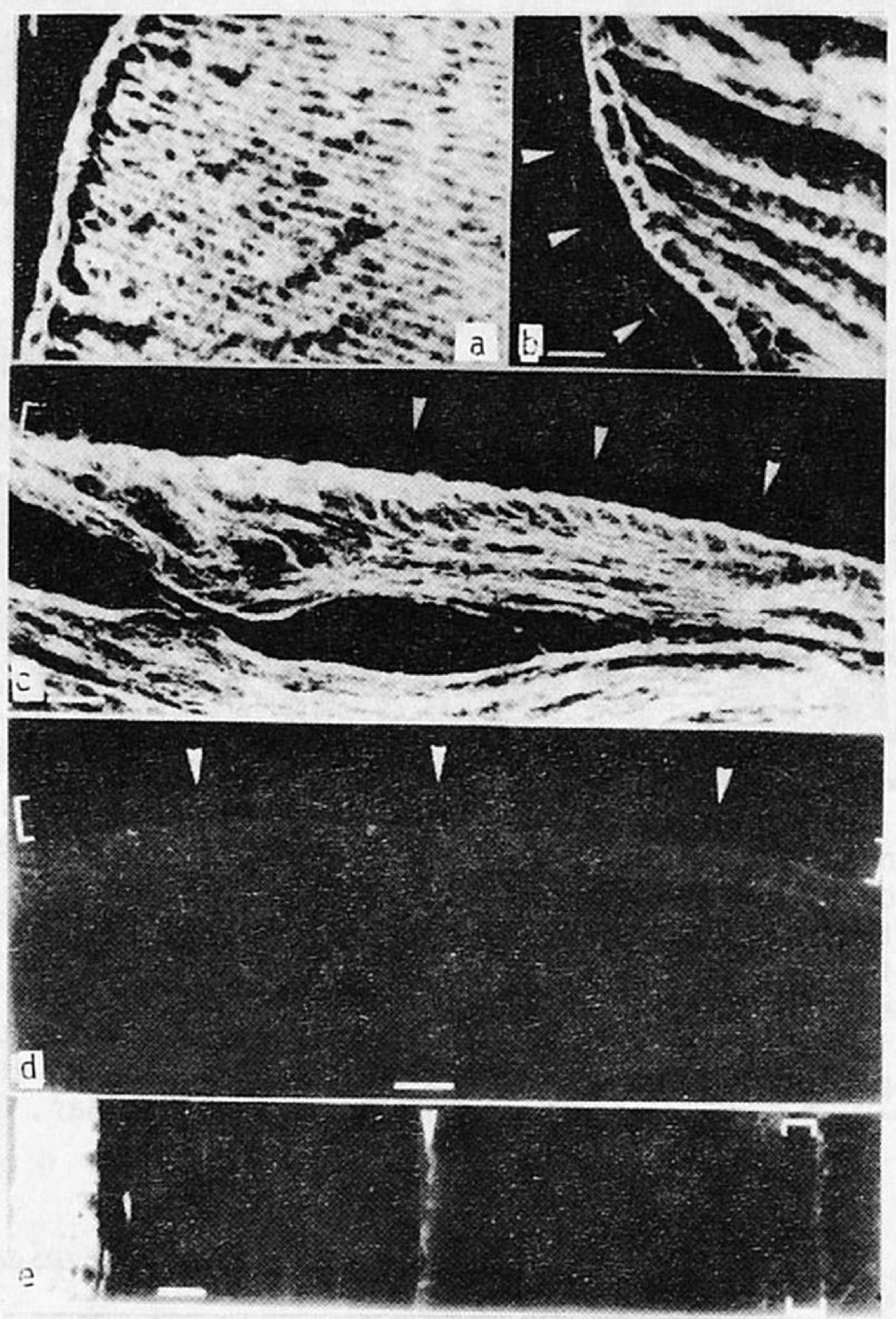

Fig 8 Immunofluorescence microscopy on frozen sections of murine lenses and eyes, respectively, using antibodies to vimentin (a-c) and prekeratin $(\underline{d}, \underline{e})$. Note intense positive reaction of outer Tens cell layer and lens fibers with antibodies to vimentin ( $a-c$, different orientations of section; $c$ is from the equatorial region of the lens where the epitheloid cells elongate and are transformed into lens fiber cells) but not with prekeratin antibodies (d, e ). Arrowheads and brackets denote contours and position of the lens capsule. Note in (e) the positive staining of the cornea (at the outer left margin) with prekeratin antibodies, and in contrast the absence of staining by prekeratin antibodies of cells of corneal stroma, corneal 'endothelium' (denoted by arrowhead in e), iris, lens capsule (bracket) and lens tissue (at the right margin). Bars denote $30 \mu \mathrm{m}$. 
Lens cells were not stained with antibodies to prekeratin (Fig 8d, e), in contrast to cornea epithelium ( $F i g ~ 8 e$ ). They were also not stained with antibodies to desmin (not shown), although in some regions, a weak spotty fluorescence along the inner side of the capsule was observed the significance of which could not be assessed.

Electron microscopy of ultrathin sections through lens tissue of bovine and murine eyes demonstrated the abundance of intermediatesized filaments in the cytoplasm of the outermost cell layer, i.e. the so-called 'lens epithelium' (Fig 9).



Fig 9 Electron micrographs presenting sections through the outer cell layers of lenses of bovine eyes, including fiber cells (F) as well as the epitheloid outermost cell layer characterized by their relatively rich endoplasmic reticulum and nuclei (bracket in a). At higher magnification of such sections $(\underline{b}, \underline{c})$ the very high density of intermediate-sized filaments is apparen $\bar{t}$. These filaments tend to form relatively loosely packed bundles running in diverse directions $(b, c)$. Cross-sections through such bundles often reveal their unstaiñed, apparently hollow core (insert in c). Bars denote $5 \mu \mathrm{m}(\mathrm{a})$, $0.5 \mu \mathrm{m}(\underline{b}, \underline{c})$, and $0.1 \mu \mathrm{m}$ (insert in $\underline{\mathrm{c}}$ ). 
In these cells the $7-11 \mathrm{~nm}$ thick intermediate-sized filaments represented the most frequent cytoplasmic structure, exceeding even membranes of endoplasmic reticulum and polyribosomes (Fig 9b, c). Characteristically, such filaments often appeared to be arranged in bundles, which, however, were never densely fasciated and showed a minimal filament interspace of ca $8 \mathrm{~nm}$ (Fig 9c).

These bundle arrays of intermediate filaments frequently were arranged at certain angles to give rise in sections to the 'herringbone' patterns described by Rafferty and Esson ${ }^{65}$ which these authors erroneously interpreted as $5 \mathrm{~nm}$ microfilaments. In the centrepetal direction of the lens the density of intermediate-sized filaments in the cytoplasm of the lens fiber cells gradually decreased, and in the innermost parts of the lenses practically no intermediate-sized filaments were recognized.

Neither in the outermost cell layer nor in the lens fiber cells did we observe desmosomes, tonofibrils or other bundles of densely fasciated intermediate-sized tonofilaments as they are typical for some forms of prekeratin and cytokeratin filaments, in agreement with Rafferty and Esson ${ }^{65}$. Gap junctions were the most predominant type of junctions observed in outer lens cells and lens fibers ${ }^{65,66}$.

\section{DISCUSSION}

Our results show that lens forming cells contain proteins of the contractile apparatus of muscle, with the exception of desmin, the protein constituent of muscle type intermediate-sized filaments and of Zlines ${ }^{19,25,26,58,67}$.

In agreement with Lonchampt et $a \ell^{30}$ we find that microfilament bundles of the 'stress-fiber' type are abundant in the cultured lens cells. Myosin, tropomyosin and $\alpha$-actinin are also found associated with these fibrils. While microfilaments have also been noted in intact lens tissue 50-52,65. Acomparison of immunofluorescence and electronmicrographs suggests that the microfilament arrays are much more frequent and organized in much thicker and longer bundles in cells grown in vitro than in the intact lenses. This might reflect stress 
fiber formation during adaptation to anchorage-dependent growth in culture, as these cells are also different from cells of the intact lens in several other properties including the pattern of crystallins synthesized and the induction of procollagen type I.

Lens cells also contain large numbers of microtubules (for electronmicroscopy see also $8,30,46,68)$. As to the specific arrays of microtubules in cultured lens cells, however, we have often observed smoothly bent, mostly radially oriented fibrils, similar to those observed in most other cultured cells $14,18,33$ but different from the cablelike 'long thick strands running in the long axis of the cell' that Lonchampt et a ${ }^{30}$ described as decorated by antibodies to tubulin in cultured lens cells. The reason for this discrepancy is unclear but it is important to note that in their study whole rabbit serum and not purified antibodies to tubulin were used.

We have also shown that cells of the outer layer of lenses as well as cultured cells derived from the capsule-attached lens cells ('lens epithelial cells') contain large amounts of intermediate-sized filaments which seem to be exclusively of the vimentin type. Both in situ and in vitro such cells do not show intermediate-sized filaments either of the desmin (for contrasting conclusions see 51,52 ) or the cytokeratin type.

In addition, gel electrophoretic analyses of cytoskeletal preparations of these cells suggest that they do not contain intermediatesized filaments made up of proteins similar to those of neurofilaments ${ }^{69}$. The absence of intermediate filaments containing proteins similar to prekeratin in the epitheloid cells of lenses, which has also recently been mentioned by Sun et $a \ell^{70}$, is surprising in view of the common classification of these cells as 'epithelial' (for refs. see Introduction) and the finding that filaments of the prekeratin type occur in a great diversity of true epithelia as well as in cultured epithelial cells $20,24,25,27,28,31,35-37,59,70$. Intermediate-sized filaments of this type have not been observed in any nonepithelial cells both in the body and in vitro $20,25,29,31,35-37,70$. Vice versa, vimentin type filaments have not been found in epithelial cells in vivo 20,31,35-37 al though they occur in many epithelial cells growing in culture $20,21,27,28,31,59$. 
The absence in lens cells of filaments stained with prekeratin antibodies corresponds to our observation of the complete absence of desmosomes in lens forming cells grown in situ65 and in vitro. Desmosomes with typical desmosomal plaques and tonofibrils are characteristic structures found in most epithelial cells $63{ }^{64}$; for an example of absence of desmosomes at a specific stage in an epithelium which normally does have desmosomes see the case of the lactating mammary gland of rodents $^{71}$ ).

While some of the properties of the junctional structures observed in earlier passages of cultured lens (e.g. Fig 7) resemble those of the special junctions described as 'modified desmosomes' in some cultured eoithelial cells $\mathrm{s}^{64}$ the absence of plaques and tonofibrils clearly distinguishes these junctions from true desmosomes.

The classification of the lens forming cells as 'epithelial' is based on their appearance as layers of flattened, closely apposed cells and on their derivation from ectodermal cells during normogenesis ${ }^{1-12}$, or from dorsal epithelium of the iris in regeneration experiments, or from pigmented embryonic retinal cells during induction in vitro $^{4}, 5$. Interestingly, the epithelialike layers covering the iris and ciliary processes all are not stained with antibodies to prekeratin but invariably contain vimentin filaments (data not shown here ${ }^{70}$ ).

These cells, together with lens cells and other early ectoderm derivatives including nerve, would therefore represent lines of ectodermal differentiation characterized by the absence of both cytokeratin filaments and true desmosomes and the presence of vimentin filaments. This allows the distinction of at least two major classes of epithelia and epitheloid formations, respectively: (i) cells which contain desmosomes and intermediate-sized filaments of the prekeratin type. This class would include epidermis and cornea, the epithelia lining the respiratory, alimentary and urinary tracts, glandular epithelia and epithelia of ducts of glands, and epithelia lining serous cavities $20,24,25,27,28,31,35-37,59,70$; (ii) cell layers of epitheloid morphology that lack desmosomes and cytokeratin type filaments but contain vimentin filaments. This class includes lens forming cells as well as epithelia of the iris and ciliary processes of the eye, endothelium, and germ epithelium of testis 29,72 . 
Whether the occurrence of different cytoskeletal elements in the two classes of epithelialike cell layers is related to different functions or developmental processes remains to be examined. In addition, the functional importance of the large amounts of vimentin filaments in lens forming cells in situ and in vitro is presently unclear. Finally, detailed studies on the appearance of the various types of intermediate-sized filaments during embryogenesis are necessary in order to decide whether the lens cells are derived from epithelial cells that contained cytokeratin filaments and/or desmosomes. Alternatively, the cells of the ectodermal lens placode may represent a special early state of ectoderm differentiation which is different from normal surface epithelia by the absence of cytokeratin filaments. 
1. Spemann, H., Experimentelle Beiträge zu eine Theorie der Entwicklung. Julius Springer, Berlin (1936, 1968) pp 1-296.

2. Coulombre, A.J., The Eye. In Organogenesis (eds. R.L. De Haan and H. Ursprung) 219. Holt, Rinehart and Winston, New York (1965).

3. Papaconstantinou, J., Science 156 (1967) 338.

4. Moscona, A.A., Science 125 (1957) 598.

5. Okada, T.S., Itoh, Y. and Eguchi, G., Dev. Biol. 45 (1975) 318.

6. Karkinen-Jääskeläinen, M., Differentiation 12 (1978) 31.

7. Vermorken, A.J.M., Hilderink, J.M.H.C., Ven van de, W.J.M. and Bloemendal, H., J. Cell Biol. 76 (1978) 175.

8. Piatigorsky, J.H., Webster de, F. and Wollberg, M., J. Cell. Biol. 55 (1972) 82.

9. Creighton, M.0., Mousá, G.Y. and Trevithick, J.R., Differentiation 6 (1976) 155.

10. Venrooij van, W.J., Groeneveld, A.A., Bloemendal, H. and Benedetti, E.L., Exp. Eye Res. 18 (1974) 527.

11. Arruti, C. and Courtois, Y., Exp. Cell Res. 117 (1978) 283.

12. Mousa, G.Y. and Trevithik, J.R., Dev. Biol. 60 (1977) 14.

13. Lazarides, E. and Weber, K., Proc. Nat1. Acad. Sci. USA 71 (1974) 2268.

14. Osborn, M., Born, T., Koitzsch, H.J. and Weber, K., Cell 14 (1978) 477.

15. Weber, K. and Groeschel-Stewart, U., Proc. Natl. Acad. Sci. USA 71 (1974) 4561.

16. Lazarides, E., J. Cell Biol. 65 (1975) 549.

17. Lazarides, E. and Burridge, K., Cell 6 (1975) 289.

18. Weber, K., Pollack, R., Bibring, T., Proc. Natl. Acad. Sci. USA 72 (1975) 459.

19. Bennett, G.S., Fellini, S.A., Croop, J.M., Otto, J.J., Bryan, J. and Holtzer, H., Proc. Natl. Acad. Sci. USA 75 (1978) 4364.

20. Franke, W.W., Schmid, E., Osborn, M. and Weber, K., Proc. Nat1. Acad. Sci. USA 75 (1978) 5034.

21. Gordon, W.E., Bushnell, A. and Burridge, K., Cell 13 (1978) 249.

22. Hynes, R.0. and Destree, Cell 13 (1978) 151. 
23. Starger, J.M., Brown, W.E., Goldman, A.E. and Goldman, R.D., J. Cell Biol. 78 (1978) 93.

24. Franke, W.W., Weber, K., Osborn, M., Schmid, E. and Freudenstein, C., Exp. Cell Res. 116 (1978) 429.

25. Sun, T.T. and Green, H., Cell 14 (1978) 469.

26. Lazarides, E., Exp. Cell Res. 112 (1978) 265.

27. Franke, W.W., Schmid, E., Weber, K. and Osborn, M., Exp. Cell Res. 118 (1979) 95.

28. Franke, W.W., Schmid, E., Winter, S., Osborn, M. and Weber, K., Exp. Cel1 Res. 123 (1979) 25.

29. Franke, W.W., Schmid, E., Osborn, M. and Weber, K., J. Cell Biol. 81 (1979) 570.

30. Lonchampt, M.0., Laurent, M., Courtois, Y., Trenchev, P. and Hughes, E.R., Exp. Eye Res. 23 (1976) 505.

31. Franke, W.W., Schmid, E., Kartenbeck, J., Mayer, D., Hacker, H.J., Bannasch, P., Osborn, M., Weber, K., Denk, H., Wanson, J.C. and Drochmans, P., Biol Cellulaire 34 (1979) 99.

32. Venrooij van, W.J., Groeneveld, A.P. and Bloemenda1, H., Exp. Eye Res. 18 (1974) 517.

33. Webster, R.E., Osborn, M. and Weber, K., Exp. Cell Res. 117 (1978) 47.

34. Rathke, P.C., Osborn, M. and Weber, K., Eur. J. Cell Biol. 19 (1979) 40.

35. Franke, W.W., Appelhans, B., Schmid, E., Freudenstein, C., Osborn, M. and Weber, K., Eur. J. Cell Biol. 19 (1979) 255.

36. Franke, W.W., Appelhans, B., Schmid, E., Freudenstein, C., Osborn, M. and Weber, K., Differentiation 15 (1979) 7.

37. Schmid, E., Tapscott, S., Bennett, G.S., Croop, J., Fellini, S.A., Holtzer, H. and Franke, W.W., Differentiation 15 (1979) 27.

38. Franke, W.W., Grund, C., Osborn, M. and Weber, K., Cytobiologie 17 (1978) 365.

39. Franke, W.W., Lüder, M., Kartenbeck, J., Zerban, H. and Keenan, T.W., J. Cell Biol. 69 (1976) 173.

40. Franke, W.W., Schmid, E., Osborn, M. and Weber, K., Cytobiologie 17 (1978) 392.

41. O'Farrell, P.H., J. Biol. Chem. 250 (1975) 4007. 
42. Bonner, W.J. and Laskey, R.A., Eur. J. Biochem. 46 (1974) 83.

43. Berns, A.J.M. and Bloemendal, H. In: Methods in Enzymology 30 (1974) 675. Academic Press, New York-London, (eds. Moldave, K. and Grossman, L.).

44. Drochmans, P., Freudenstein, C., Wanson, J.C., Laurent, L., Keenan, T.W., Stadler, J., Leloup, R. and Franke, W.W., J. Cell Biol. 79 (1978) 427.

45. Mungyer, G. and Jap, P.H.K., Interdiscipl. Topics Geront. 12 (1978) 13. Karger, Basel, ed. Hahn, H.P.V.

46. Laurent, M.V., Lonchampt, M.0., Regnault, F., Tassin, J. and Courtois, Y., Exp. Cell Res. 115 (1978) 127.

47. Vermorken, A.J.M., Groeneveld, A.A., Hilderink, J.M.H.C., Waal de, R. and Bloemendal, H., Mol. Biol. Rep. 3 (1977) 371.

48. Courtois, Y., Simonneau, L., Tassin, J., Laurent, M.V. and Malaise, E., Differentiation 10 (1978) 23.

49. Mark von der, K., Mark von der, H., Timpl, R. and Trelstad, R.L., Develop. Biol. 59 (1977) 75.

50. Bloemendal, H., Benedetti, E.L., Ramaekers, F.C.S., Dunia, I., Kibbelaar, M. and Vermorken, A.J.M., Mol. Biol. Rep. 5 (1979) 99.

51, Kibbelaar, M.A., Selten-Versteegen, A.M.E., Dunia, I., Benedetti, E.L. and Bloemendal, H., Eur. J. Biochem. 95 (1979) 543.

52. Maisel, H., Lieska, N. and Bradley, R., Experientia 34 (1978) 352.

53. Osborn, M. and Weber, K., Europ. J. Cell Biol. 20 (1979) 28.

54. Lasser, A. and Balazs, E.A., Exp. Eye Res. 13 (1972) 292.

55. Maisel, H. and Perry, M.M., Exp. Eye Res. 14 (1972) 7.

56. Maisel, H., Experientia 15 (1977) 525.

57. Bloemendal, H., Kibbelaar, M.A., Ramaekers, F.C.S., SeltenVersteegen, A.M.E., Dunia, I. and Benedetti, E.L. In: Protides of the Biological Fluids, ed. Peeters, H., Pergamon Press Oxford-New York (1979) 499.

58. Hubbard, B.D. and Lazarides, E., J. Cell Biol. 80 (1979) 166.

59. Franke, W.W., Schmid, E., Breitkreutz, D., Lüder, M., Boukamp, P., Fusenig, N.E., Osborn, M. and Weber, K., Differentiation 14 (1979) 35 .

60. Cabral, F. and Gottesman, M.M., J. Biol. Chem. 254 (1979) 6203. 
61. O'Connor, C.M., Balzer, D.R. and Lazarides, E., Proc. Nat1. Acad. Sci. USA 76 (1979) 819.

62. Wang, E. and Goldman, R.D., J. Cell Biol. 79 (1978) 708.

63. Staehelin, L.A., Int. Rev. Cytol. 39 (1974) 191.

64. Zerban, H. and Franke, W.W., Cytobiologie 18 (1978) 360.

65. Rafferty, N.S. and Esson, E.A., J. U1trastruct. Res. 46 (1974) 239.

66. Bloemenda1, H., Zweers, A., Vermorken, F., Dunia, I. and Benedetti, E.L., Cell Differentiation 1 (1972) 91.

67. Lazarides, E. and Hubbard, B.D., Proc. Nat1. Acad. Sci. USA 73 (1976) 4344.

68. Kuwabara, T., Arch. Ophthalmol. 79 (1968) 189.

69. Liem, R.K.H., Yen, S.H., Salomon, G.D. and Shelanski, M.L., J. Cell Biol. 79 (1978) 637.

70. Sun, T-T., Shih, C. and Green, H., Proc. Natl. Acad. Sci. USA 76 (1979) 2813.

71. Pitelka, D. In: Lactation, ed. Larson, B.L., Vol. 4, 41, Academic Press, New York-London (1978).

72. Franke, W.W., Grund, C. and Schmid, E., Eur. J. Cell Biol. 19 (1979) 269.

73. Lloyd, C.W., Smith, C.G., Woods, A. and Rees, D.A., Exp. Cell Res. 110 (1977) 427. 


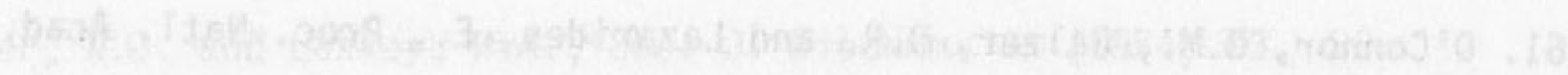

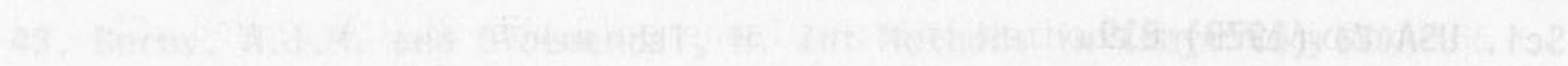

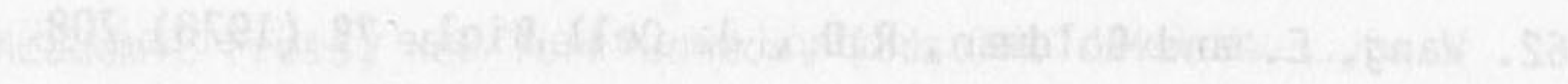

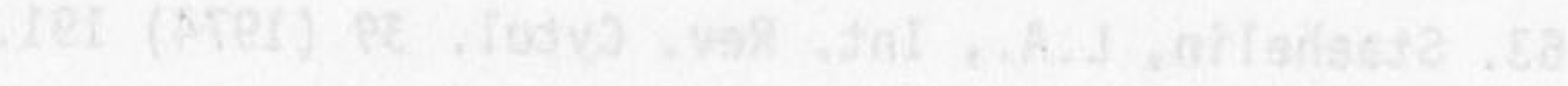

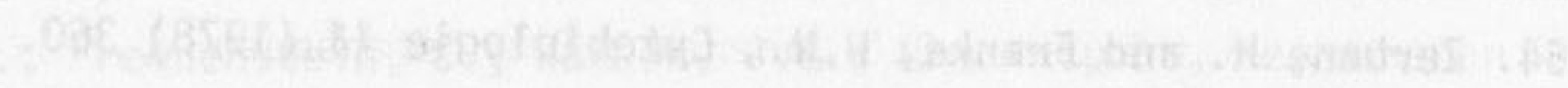

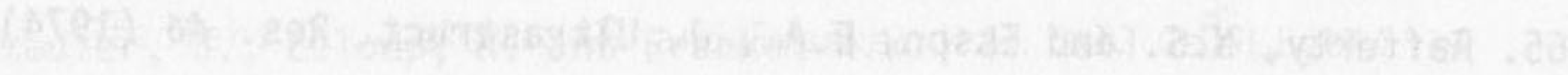

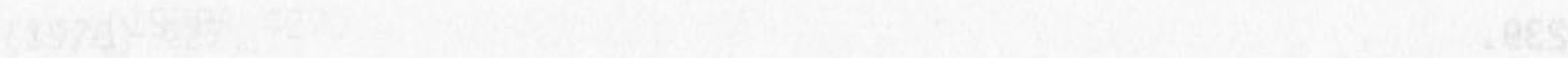

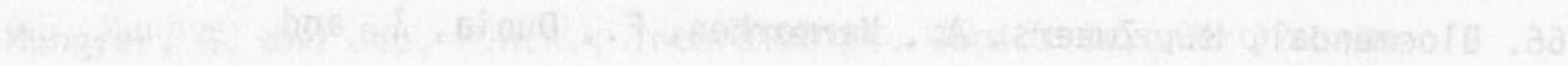

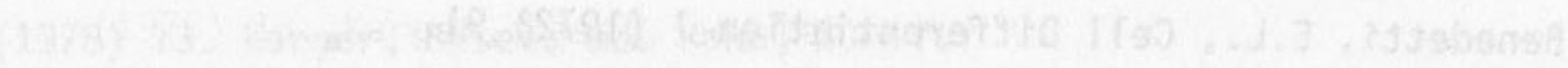

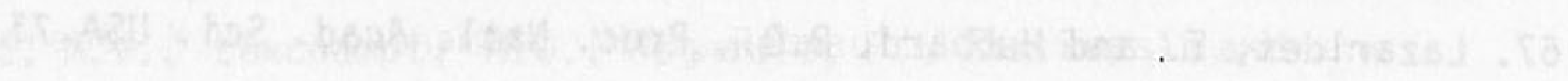

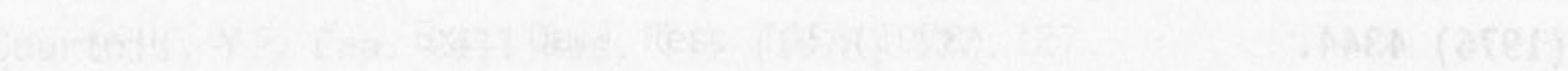

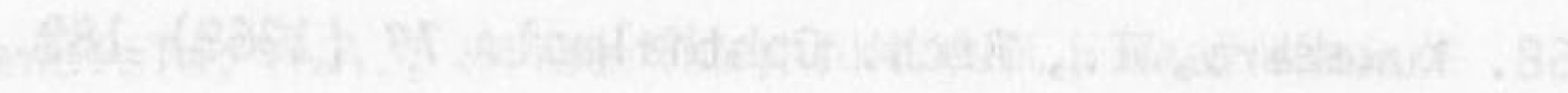

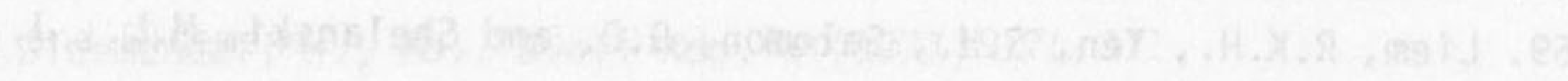

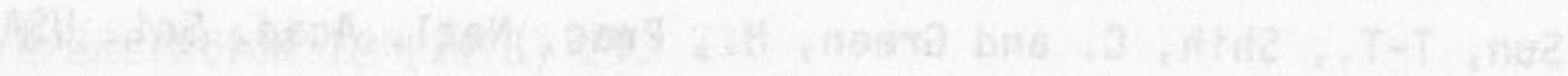

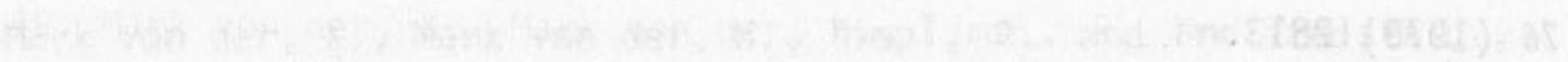

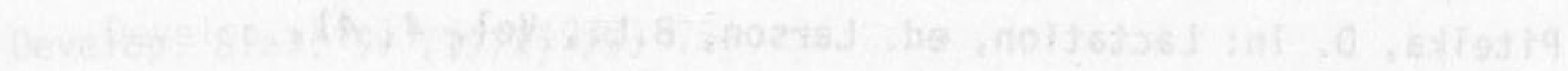

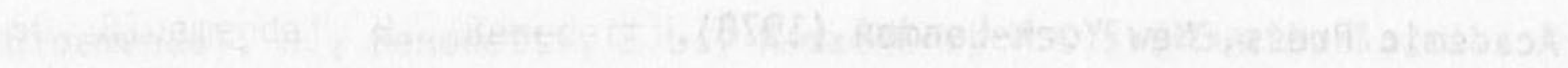

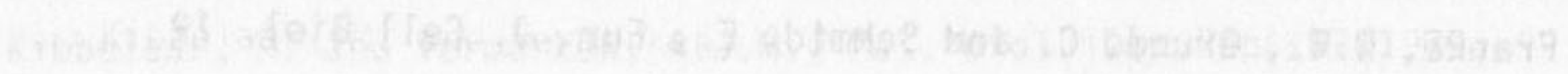

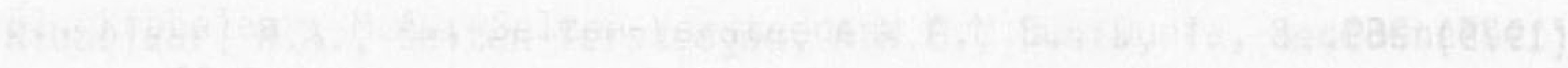

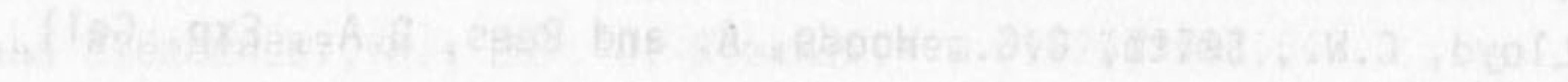


CHAPTER III

LENTICULAR INTERMEDIATE-SIZED FILAMENTS.

BIOSYNTHESIS AND INTERACTION WITH THE PLASMA MEMBRANE 
CHAPTER III

LENTICULAR INTERMEDIATE-SIZED FILAMENTS. BIOSYNTHESIS AND INTERACTION WITH THE PLASMA MEMBRANE

SUMMARY

Electron microscopical features of the lens plasma membrane cytoskeletal complex are suggestive for an intimate association between the intermediate-sized filaments (IF) and the lipid bilayer. Biochemical analysis of the complex reveals the occurrence of an appreciable amount of vimentin as protein subunit of lenticular IF.

Additional evidence for the association between IF and membranes is provided by the observation that newly synthesized vimentin is inserted into plasma membranes added to a reticulocyte lysate programmed with lens polyribosomes. Concomitantly a-crystallin polypeptide chains $(\alpha A 2)$ are also found to be associated with the plasma membranes together with a hitherto unidentified 47 kdalton protein. Once inserted into the lipid bilayer the vimentin polypeptide resists urea treatment suggesting that it has become an integral part of the membrane.

INTROOUCTION

Better insight into the function of the cytoskeleton in nonmuscle cells requires the elucidation of the nature of the link between cytoskeletal and motility proteins and the cell membranes. The complexity of this interaction has been demonstrated in several biological systems where a variety of proteins seems to be involved in the attachment of the cytoskeletal elements to the lipid bilayerl. Whether or not protein subunits of the cytoskeleton are comprised within the lipid membrane core as integral membrane components is still an open question.

Recently great interest has been focused on the intermediate-sized filaments ${ }^{2}$ which, together with microtubules and microfilaments constitute the intracellular matrix of eukaryotic cells. Intermediate- 
sized filaments (IF) have been subdivided into five classes according to the embryonicorigin of the cell type and the kind of their protein subunit ${ }^{3}$.

IF have been described in intact lens, where they contribute to the organization of the cytoskeleton of both the epithelial calls and the lens fibers ${ }^{4-6}$. Moreover, we have reported the presence of IF in cultured lens cells $\mathrm{s}^{6-8}$. Immunofluorescence studies and biochemical data indicate that the protein moiety of these IF is vimentin 6 . Electron microscopical evidence has been provided for an end on attachement of IF to the cytoplasmic site of the lens fiber plasma membranes ${ }^{9}$. The link of IF with various types of membranes has been postulated as nucleation site for filament formation. These reports, however, are mainly confined to the interaction of prekeratin IF with desmosomes ${ }^{10}$, of desmin IF with the intercallating disks in muscle ${ }^{l l}$ and vimentin IF with the nuclear membrane ${ }^{12}$. Nevertheless, the nature of these interactions is still obscure.

In this chapter we show that the lenticular IF are intimately associated with the plasma membranes. Moreover, we demonstrate that vimentin, newly synthesized in vitro is found as intrinsic constituent of added purified lens fiber plasma membranes.

\section{MATERIALS AND METHODS}

Isolation of lens fiber plasma membranes

Fresh calf lenses were decapsulated and homogenized by continuous stirring for $2 \mathrm{~h}$ in either bicarbonate buffer ( $1 \mathrm{mM} \mathrm{NaHCO}, 1 \mathrm{mM} \mathrm{CaCl} 2$ ) or TKM-buffer ( $50 \mathrm{mM}$ Tris- $\mathrm{HCl}, \mathrm{pH} 7.4,25 \mathrm{mM} \mathrm{KCl}$ and $5 \mathrm{mM} \mathrm{MgAc} 2$ ).

Plasma membranes were isolated by discontinuous sucrose gradient centrifugation as described earlier ${ }^{3}$ either in bicarbonate- or TKMbuffer. The plasma membrane fractions obtained at sucrose densities $1.20-1.22 \mathrm{~g} / \mathrm{cm}^{3}, 1.18-1.20 \mathrm{~g} / \mathrm{cm}^{3}$ and $1.16-1.18 \mathrm{~g} / \mathrm{cm}^{3}$, were washed three times in the respective buffers and sedimented in a Ti 50 rotor.

In the isolation procedure, using TKM-buffer, a membrane containing layer is only formed at a density $1.20-1.22 \mathrm{~g} / \mathrm{cm}^{3}$. Protein concentrations were determined as described by Lowry ${ }^{14}$. 
De novo synthesis of lens proteins

Calf lens polyribosomes were isolated as described by Bloemendal et a ${ }^{15}$. Rabbit reticulocytes were prepared as described either by Evans and Lingre ${ }^{16}$ or by Pelham and Jackson ${ }^{17}$. A 30,000 $\times \mathrm{g}$ supernatant fraction of the lysed cells was used as cell-free system, and incubations were performed at $30^{\circ} \mathrm{C}$ for $1 \frac{1}{2} \mathrm{~h}$. The reaction mixture contained

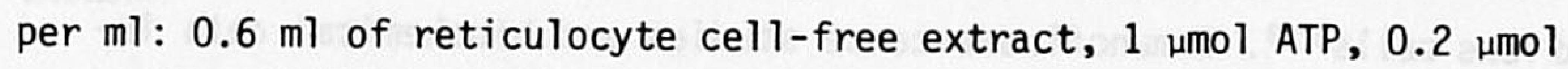
GTP, $50 \mu \mathrm{g}$ tRNA, 4 mol dithioerithrol, $10 \mu \mathrm{mol}$ creatine phosphate, $100 \mu \mathrm{g}$ creatine phosphokinase, $0.2 \mu \mathrm{mol}$ spermidine, $100 \mu \mathrm{mol}$ potassium chloride, 1 umol magnesium acetate, and $0.1 \mu \mathrm{mol}$ of 19 amino acids, $100 \mu 1$ of $\left[{ }^{35} \mathrm{~S}\right]$-methionine was added as only labelled amino acid.

The lysate was made mRNA dependent by preincubation with $10 \mu \mathrm{g} / \mathrm{ml}$ micrococcal nuclease in the presence of $1 \mathrm{mM} \mathrm{CaCl} l_{2}$ for 15 min at $20^{\circ} \mathrm{C}$ as described by Pelham and Jackson ${ }^{17}$. After the incubation $2 \mathrm{mM}$ ethyleneglycol (2 aminoethylether) $N, N^{1}$-tetraacetic acid (EGTA) was added to chelate the calcium ions. Polyribosomes were added in a concentration of 0.4-1 mg per $\mathrm{ml}$ (determined spectrophotometrically and assuming an extinction coefficient of 13 at $260 \mathrm{~nm}$ ).

L- $\left[{ }^{35} \mathrm{~S}\right]$-methionine (specific activity $500 \mathrm{Ci} / \mathrm{mmole}$ ) was purchased from the Radiochemical Centre, Amersham (England). Radioactivity was determined in a Packard liquid Scintillation counter type 2450.

Incubation and re-isolation of lens plasma membranes

Ninety min after addition of lens polyribosomes the reticulocyte cell-free incubation was supplemented with purified lens plasma membranes, isolated either in bicarbonate or TKM-buffer. In some experiments bicarbonate isolated membranes that were exhaustively washed with $6 \mathrm{M}$ urea were used. The total mixture was incubated as indicated at $30^{\circ} \mathrm{C}$ under occasional stirring. When membranes isolated in TKMbuffer were added to the reticulocyte cell-free system, the ionic conditions of this incubation were adjusted to the salt-concentrations of the TKM-buffer. Then the membranes were re-isolated in bicarbonate or TKM-buffer as described above or simply by centrifugation in a minifuge.

The membrane pellets were dissolved for gel electrophoretic analysis. 


\section{Polyacrylamide gel electrophoresis}

Analysis of the polypeptides was performed by sodium dodecylsulphate-polyacrylamide gel electrophoresis according to Laemmlili with the modification that slab gels instead of gel rods were used.

The gels were $12 \mathrm{~cm}$ long and contained either a 13\% SDS acrylamide gel or a $7-18 \%$ acrylamide gradient, $0.4 \%$ methylene-bisacrylamide and $0.1 \%$ sodium dodecylsulphate. In this method a stacking gel was applied. Staining and destaining were performed as described by Weber and Osborn ${ }^{19}$.

Gels were processed for autoradiography. For the detection of the labelled proteins the procedure of Bonner and Laskey 20 was used in combination with the drying procedure described by Berns and Bloemen$\mathrm{da}^{21}$. Two-dimensional gel electrophoresis, using isoelectric focussing in the first dimension was performed according to the method of 0 'Farrell et al22.

\section{Electron microscopy}

Electron microscopic observations on the isolated lens fiber plasma membrane cytoskeleton complex have been carried out on thin sections fixed in gluteraldehyde osmium tetroxyde and embedded in Vestopal ${ }^{23}$ or by the negative staining technique. Freeze fracture experiments have been performed on isolated fractions that were rapidly frozen in liquid Freon 22. The freeze fracture replica has been obtained in a Balzers BAF- 301 .

The unfixed specimens were fractured at $-150^{\circ} \mathrm{C}$. The replica was made immediately after the fracture by evaporation of platinum and carbon using an electron gun ${ }^{24}$. A Philips EM 400 was used.

\section{RESULTS}

Electron microscopical observation demonstrates a striking difference when the membrane fraction instead of being isolated in sodium bicarbonate is fractionated under cytoskeleton stabilizing conditions. In the former method the plasma membranes are practically devoid of filamentous structures, whereas when the cytoskeletal organization is pre- 
served IF and actin filaments are clearly visualized in close association with the inner side of the membrane (Fig la). In thin sections of the plasma membrane cytoskeleton complex it is shown that the IF have an end on attachment to the cytoplasmic surface of the plasina membrane.

In Fig $1 \mathrm{~b}$ a high resolution electron micrograph of isolated IF is shown. From this picture the subunit organization of these structures becomes clearly visible showing the three or four subfilaments that build up the IF.

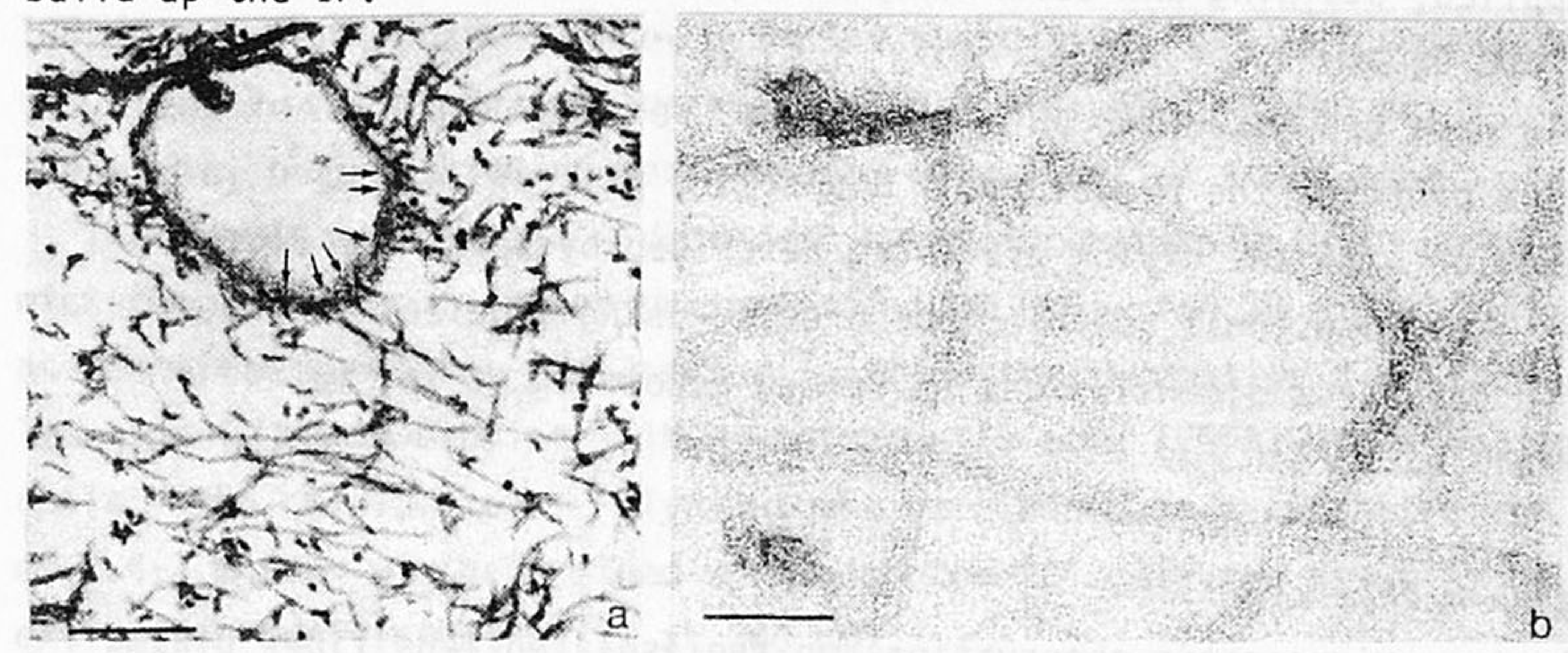

Fig la Transmission electron microscopic observation of the isolated lens fiber plasma membrane cytoskeleton complex. Intermediatesized filaments $(10 \mathrm{~nm})$ are running in different directions and have end on attachments to membrane profiles (arrows). Bar indicates $200 \mathrm{~nm}$.

Fig 16 Isolated intermediate-sized filaments negatively stained by $1 \%$ uranyl acetate. Note the subunit organization of the filaments, probably consisting of three or four subfilaments. Bar indicates $50 \mathrm{~nm}$.

The intimate nature of the association between IF and membrane leaflets is further demonstrated by freeze fracture aspects of the lens fiber plasma membranes. These rodlike structures are continuous with filaments found in the cytoplasmic space where the fracture aspects of the cytoskeleton structure are visible (Fig 2).

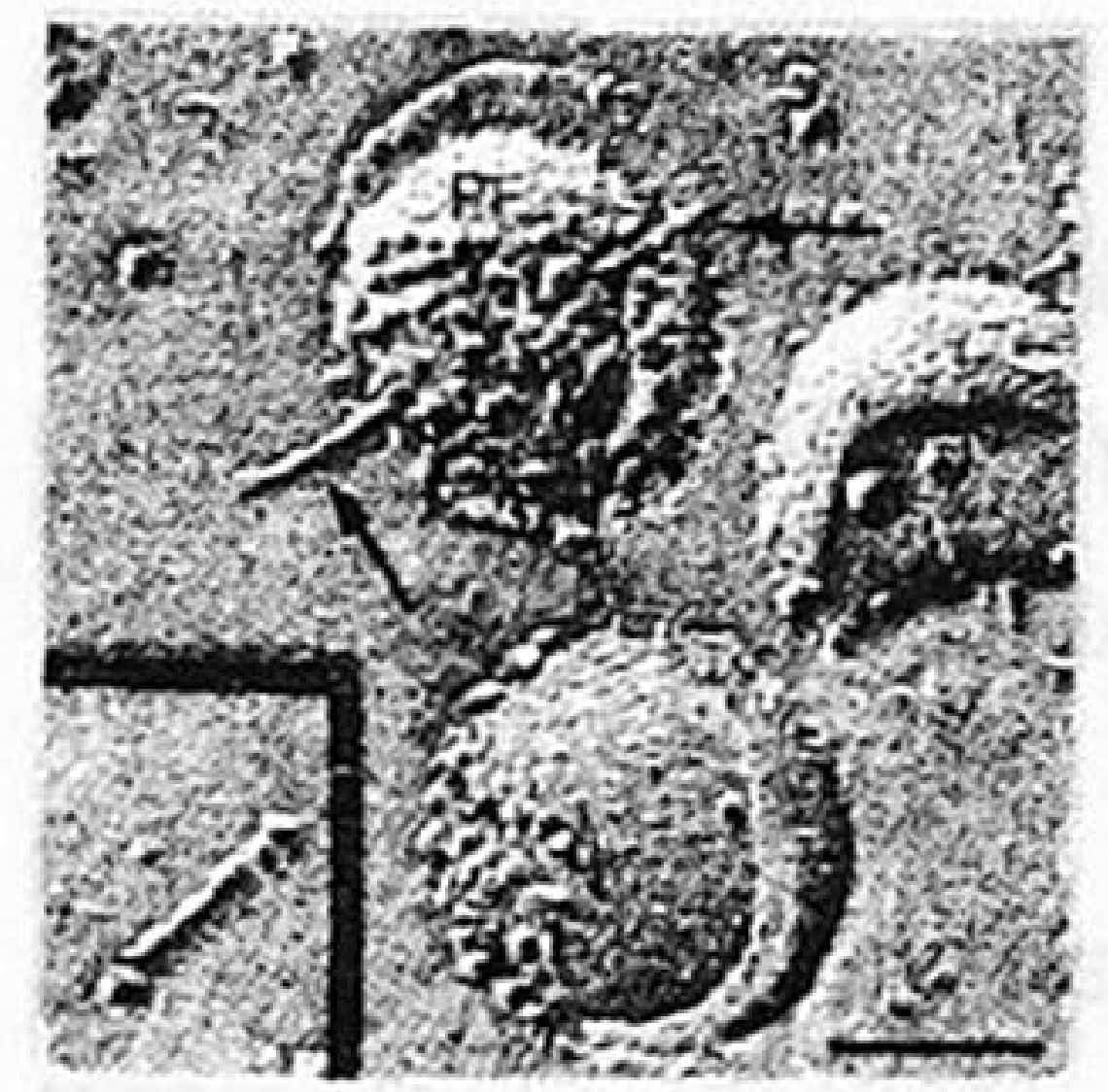

Fig 2 Freeze fracture replica of the isolated lens fiber plasma membrane cytoskeleton complex. The arrows point to rodlike structures that apparently have an end on association at the protoplasmic fracture face (PF), studded by intramembranous particles of a heterogeneous size. Rodlike structures are also visible far from the membranes (insert). The average diameter of the rodlike entities is about 10-11 nm. Bar indicates $100 \mathrm{~nm}$. 
The rods (most probably corresponding to longitudinal fractures of IF) are mainly associated to the protoplasmic membrane fracture face (PF) where they are closely packed with intramembranous particles.

SDS-gel electrophoretic analysis of the cytoskeleton membrane complex shows are very strong band, migrating in the molecular weight region of vimentin (Fig 3 ).

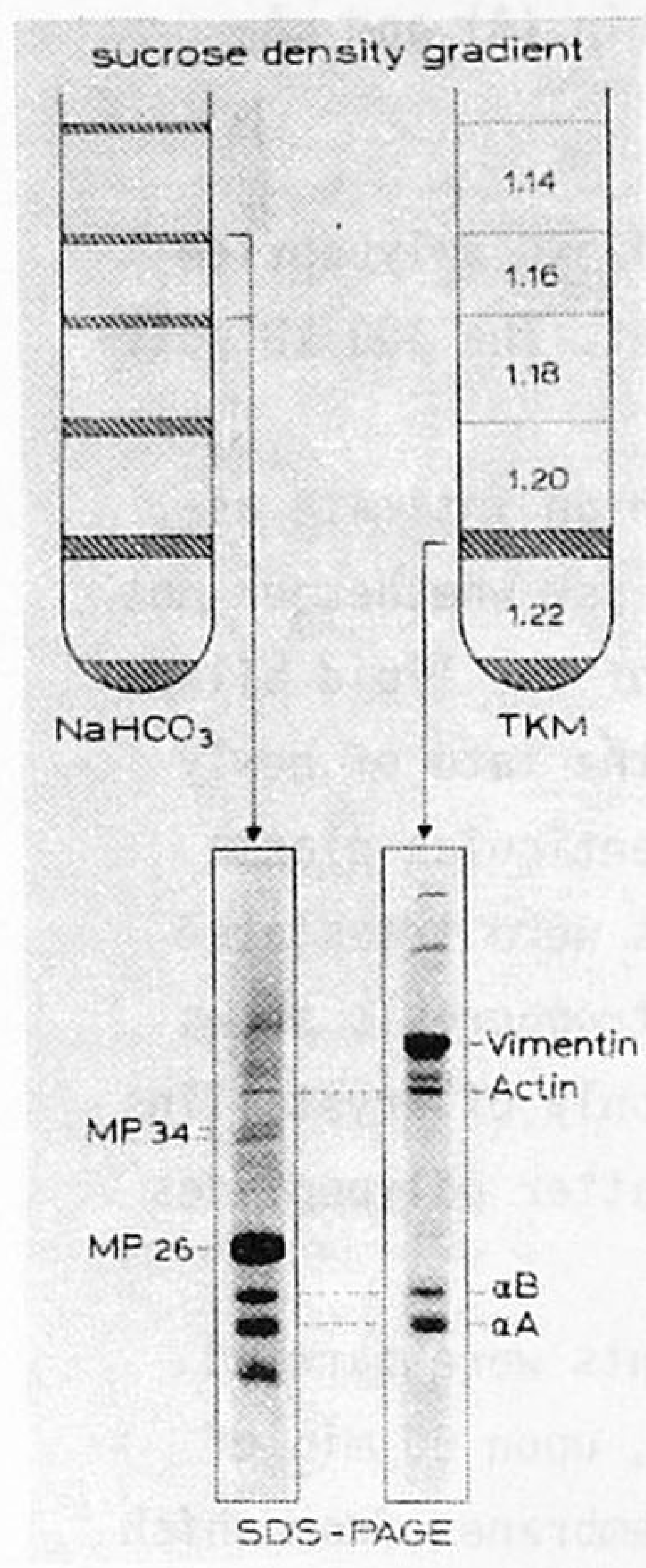

Fig 3 The drawing depicts the final step of the purification of lens fiber plasma membranes in sucrose density gradients. In one case the plasma membranes were isolated in $1 \mathrm{mM} \mathrm{NaHCO}$ and low temperature. Under these conditions electron microscopic observation showed that the membrane fractions gathered at the interfase 1.16 and $1.14 \mathrm{~g} / \mathrm{cm}^{3}$ are almost completely devoid of filamentous structures. Some remnants of the cytoskeleton are found in the plasma membrane fraction gathered at interfase 1.18 and $1.20 \mathrm{~g} / \mathrm{cm}^{3}$. The protein profile of the pool of membrane fractions isolated in $\mathrm{NaHCO}_{3}$ indeed contains a minor component comigrating with actin and practically no vimentin. Conversely, the major polypeptides are represented by the intrinsic membrane components MP26 and MP 34 , and $\alpha$-crystallin polypeptides. The MP34 is represented by a doublet.

When during isolation cytoskeleton-stabilizing conditions are used (TKM) and the whole isolation procedure is carried out at $15^{\circ} \mathrm{C}$, SDS-gel electrophoretic patterns of the plasma membrane cytoskeleton complex are now characterized by a predominant band in the $57,000 \mathrm{~mol}$ weight region, comigrating with vimentin. Another protein band comigrates with actin.

Less heavily stained bands represent the $\alpha$-crystallin subunits, actin and a $47 \mathrm{kD}$ polypeptide. The lens fiber membrane proteins MP26 and MP $34^{25}$ are masked by the predominance of the cytoskeletal polypeptides. Only after removal of the cytoskeleton by bicarbonate washings and subsequent re-isolation by flotation of the membranes the MP26 and a doublet in the $34 \mathrm{kD}$ region become clearly visible on the electropherogram (Fig 3 ).

The cytoskeletal polypeptides were further characterized by 2D-gel electrophoresis. In the 2D-slab gel pattern (Fig 4 ) it can be seen 


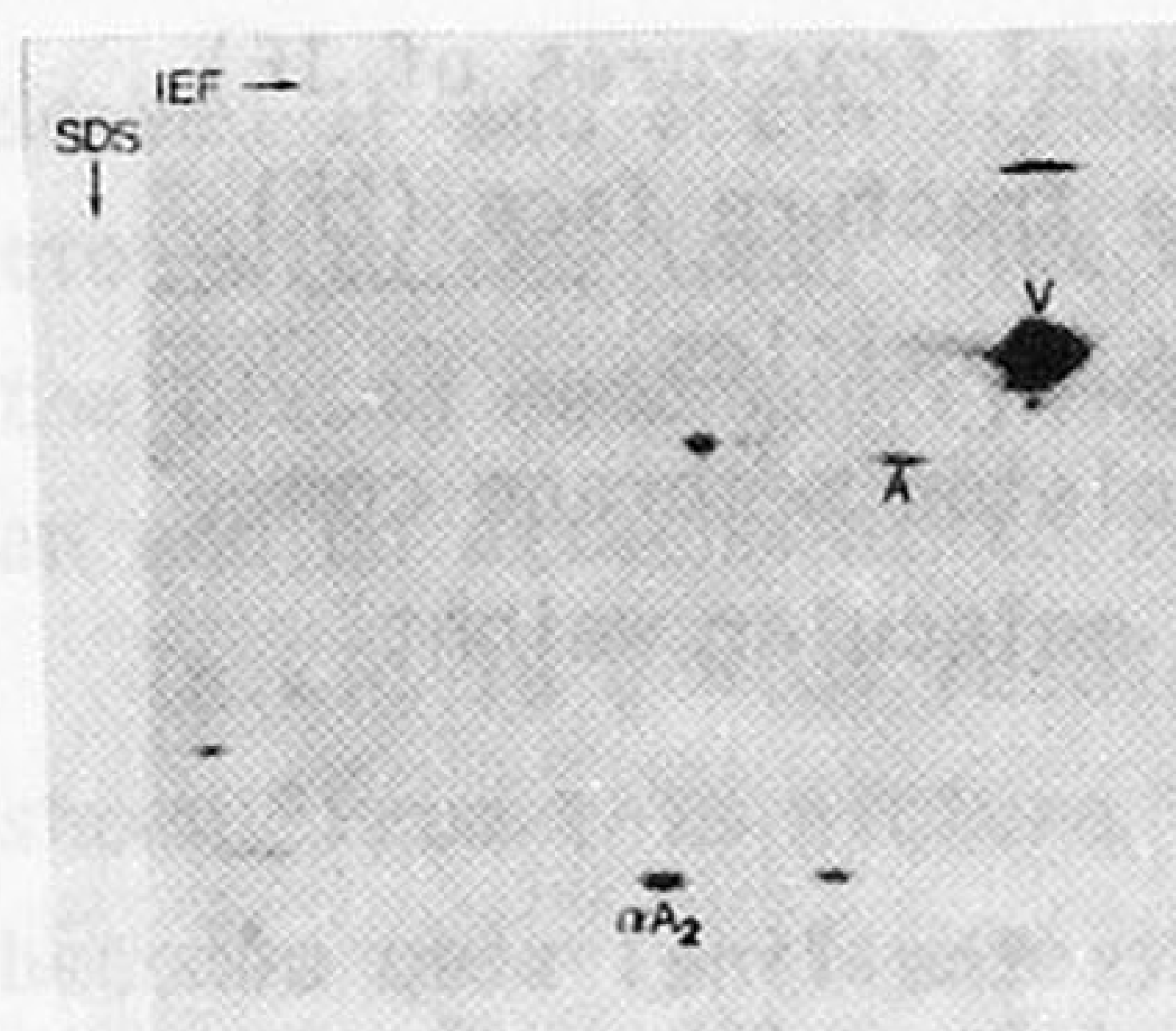

Fig 4 Two-dimensional gel electrophoretic analys is of the isolated plasma membrane cytoskeleton complex. Gel electrophoresis has been carried out by a combination of isoelectric focusing in 9 M urea followed by electrophoresis in $0.1 \%$ SDS ( $13 \%$ polyacrylamide slab ge 1$)$. The pattern is characterized by one major component which comigrates with vimentin ( $V$ ) and by other minor components, among which actin (A) and $\alpha \mathrm{A}_{2}$ crystallin.

that vimentin is the most abundant component. The $47 \mathrm{kD}$ polypeptide strongly differs from actin in its isoelectric point. The $100 \mathrm{kD}$ polypeptide presumably corresponds to $\alpha$-actinin.

As the morphological evidence was suggestive for an intimate association between plasma membranes and IF, one may ask whether or not the IF protein subunit(s) are integral components of the lipid bilayer. In order to answer this question, we examined the fate of newly synthesized vimentin in the presence of purified lenticular plasma membranes in vitro. Therefore, lens fiber polysomes were translated in a reticulocyte lysate. Two-dimensional gel electrophoresis shows that these polyribosomes direct the synthesis not only of crystallins but also of cytoskeletal polypeptides. Among the latter polypeptides vimentin again is predominant ( Fig $5 \mathrm{a}$ ).

Thereafter the following recombination experiments were carried out. The lens polysome-reticulocyte lysate mixture, upon $90 \mathrm{~min}$ of incubation was supplemented with purified plasma membranes from which the cytoskeleton was detached by bicarbonate washings. Incubation was continued for $1 \mathrm{~h}$ and the membranes were re-isolated by flotation. Twodimensional electrophoretic analyses yielded the pattern shown in Fig $5 b$.

Obviously, only a few components have been selected from the de novo synthesized protein population, namely the major $\alpha$-crystall in chain $A_{2}$ and the intermediate-sized filament constituent vimentin. In addition the yet unidentified $47 \mathrm{kD}$ protein becomes also associated with the plasma membranes.

It is not very likely that the attachment of vimentin is due to 


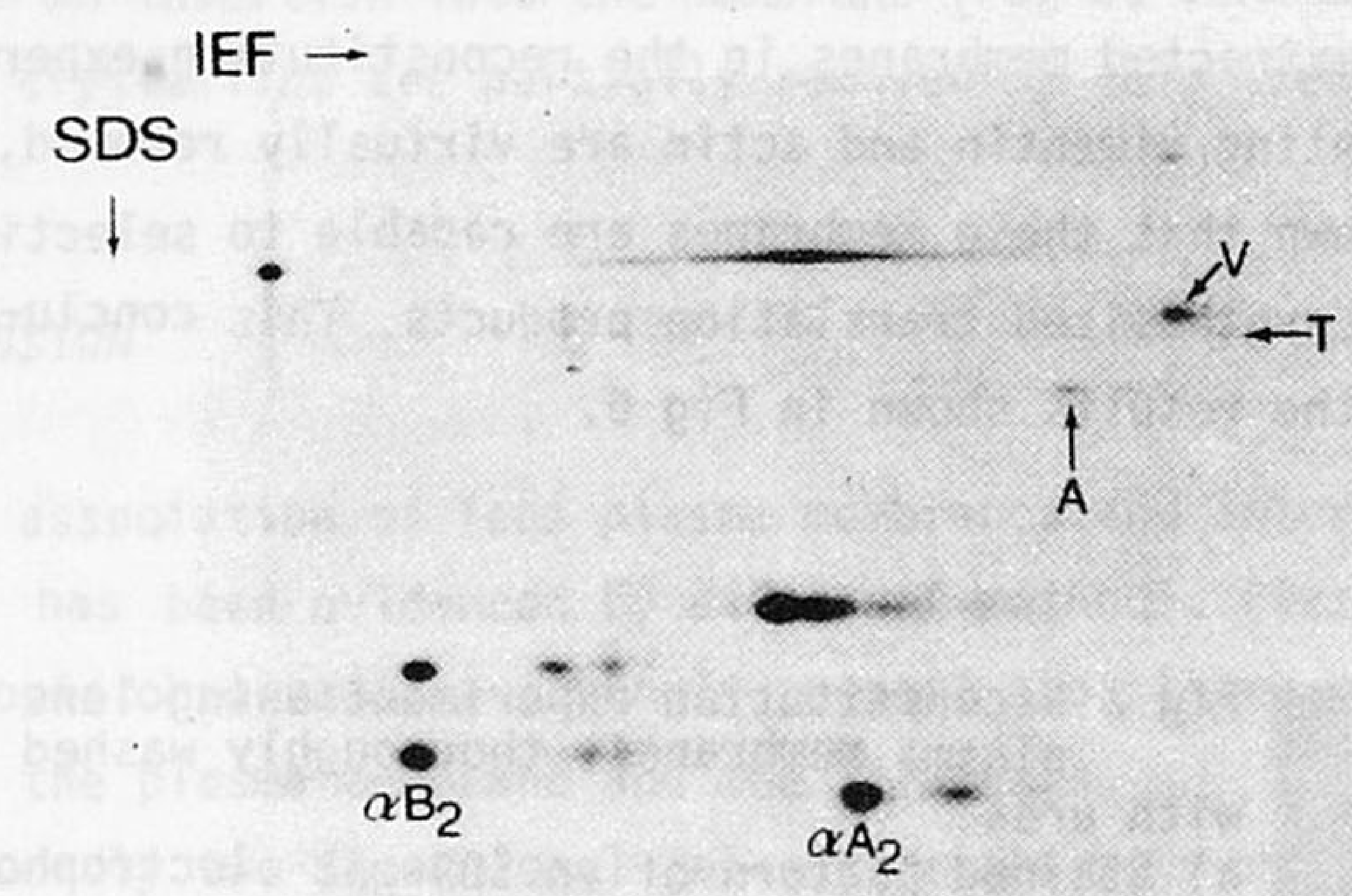

a

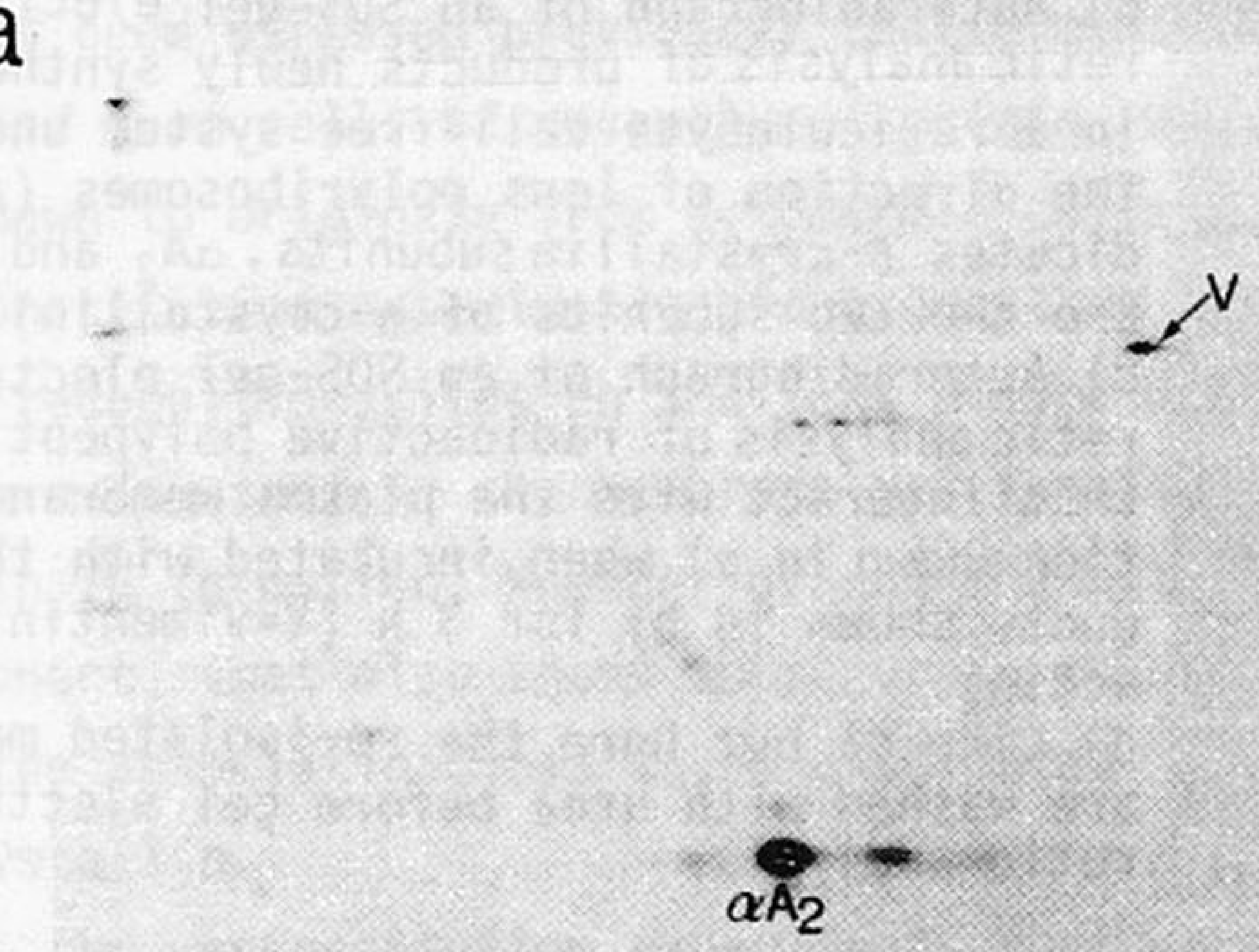

b

Fig 5 a) Two-dimensional gel electrophoretic pattern of the products obtained after translation of free lens fiber polyribosomes. Note that among these products both vimentin and actin are present.

b) Lens fiber plasma membranes isolated in bicarbonate and thouroughly washed in the same medium have been incubated for one hour with the newly synthesized products of translation directed by the lens polyribosomes in a reticulocyte cell-free system. After re-isolation, even after repeated washing in bicarbonate buffer, the membranes retain selectively vimentin, $\alpha A_{2}$ and MP47, but not actin and other polypeptides visualized in (a). 
exchange or interaction between preexisting and newly synthesized IF protein. Using urea-extracted membranes in the reconstitution experiments, where preexisting vimentin and actin are virtually removed, it can clearly be shown that these membranes are capable to selectively sort out newly synthesized translation products. This conclusion is sustained by the results shown in Fig 6 .

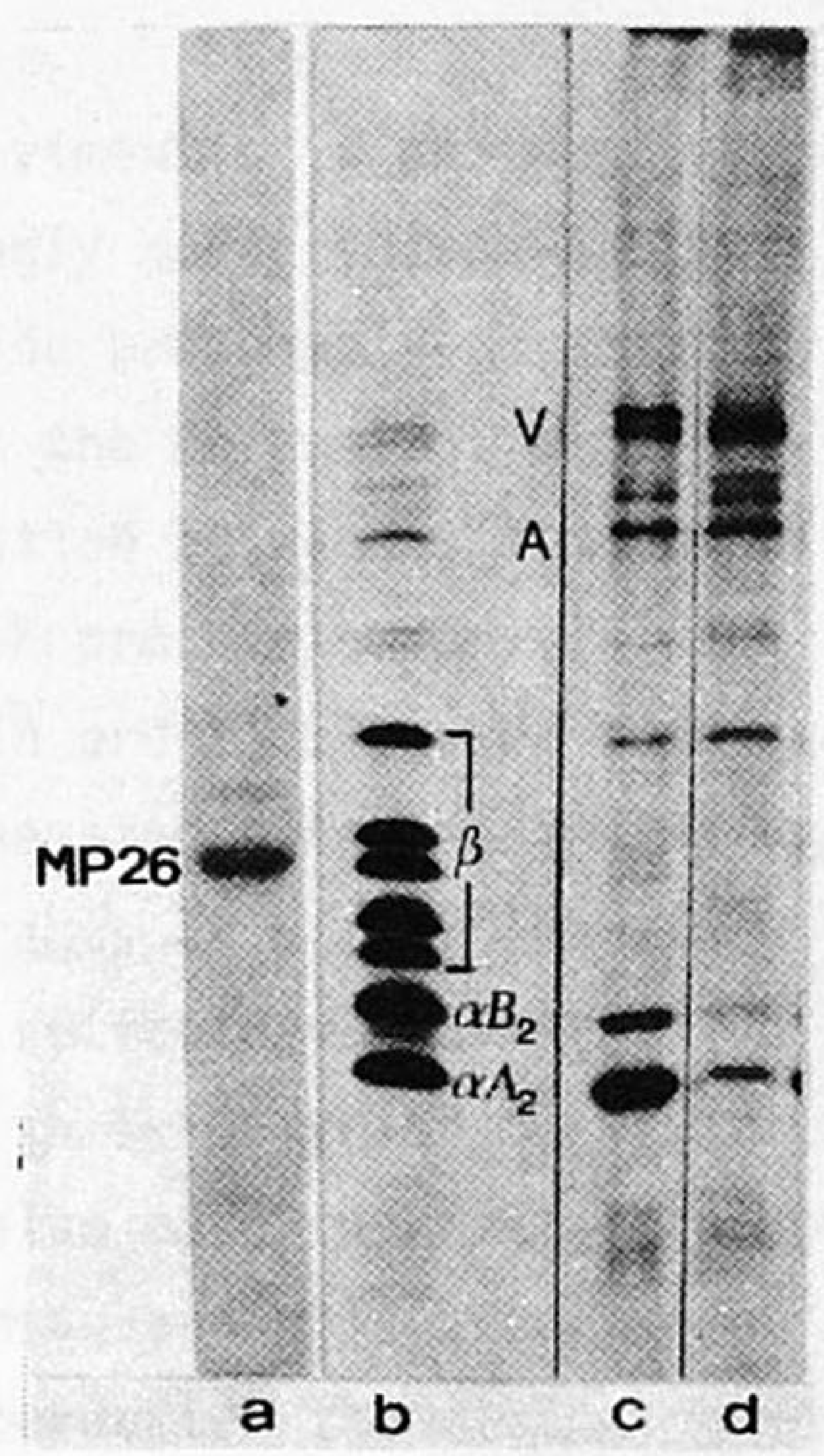

Fig 6 Reconstitution experiment using lens with urea. plasma membranes, thouroughly washed

a) Stained pattern of an SDS-gel electrophoretic analysis of the membrane fraction used in this experiment. Note that next to MP26 virtually no protein bands are present. b) Autoradiograph of an SDS-gel electrophoretic analysis of products newly synthesized in a reticulocyte cell-free system under the direction of lens polyribosomes ( $B$ indicates $\beta$-crystallin subunits, $\alpha A_{2}$ and $\alpha B_{2}$ are the two subunits of $\alpha$-crystallin). c) Autoradiograph of an SDS-gel electrophoretic analysis of radioactive polypeptides that interact with the plasma membrane fraction shown in a) when incubated with the products shown in b) for $3 \mathrm{~h}$ (V=vimentin; $A=$ actin).

d) Like c) but here the re-isolated membranes are washed with urea before gel electrophoretic analysis.

Among the products of translation shown in lane $b$, vimentin preferentially interacts with the membranes (Fig 6, lane c). Also actin, MP47, $\alpha A$ and $B B_{1 a}$ are sorted out. Conversely, in spite of the fact that (other) B-crystallins have been synthesized de novo in appreciable amounts, they are not found to be associated with the membrane. This latter result clearly indicates that there is no exchange between preexisting and newly synthesized polypeptides but a selective integration of specific classes of protein. The results of the experiment illustrated in this Figure also show that the newly inserted vimentin becomes strongly attached, because it resisted further urea extrac- 
tion after insertion into the membrane (Fig 6, lane d). On the other hand, crystallins are partially removed by this treatment.

\section{DISCUSSION}

Close association of lens plasma membranes and intermediate-sized filaments has been evidenced by different methods. Firstly electron microscopic observations strongly suggest that there exists contact between the plasma membrane and the filaments.

Secondly two-dimensional gel electrophoresis reveals that vimentin, the subunit of lenticular IF, is a predominant component in the protein pattern obtained from the lens plasma membrane cytoskeleton complex. It has been stressed previously that vimentin normally is found in IF derived from cells of mesenchymal origin, whereas the eye lens has been shown to originate from ectodermal cells ${ }^{6}$.

Our reconstitution experiments are suggestive for the existence of binding or recognition sites on the lens plasma membrane for IF. Protein components present in the membrane may function as nucleation sites for vimentin IF formation. Whether or not the hitherto unidentified 47 KD component, that also seems to occur in other cell-types 26 is involved in the association, has to be elucidated. The same holds true for $\alpha A_{2}$-crystallin.

However, the reconstitution experiments that were performed with urea-extracted membranes indicate that also the vimentin protein subunit per se can be inserted into the membrane lipid bilayer, thereby thus forming its own nucleation site. This would mean that IF in lens do not need a protein intermediate for membrane attachment, as suggested for other filamentous structures, such as a-actinin for microfilament-membrane associations.

The finding that IF are associated in appreciable amounts with the plasma membranes of lens fibers, is suggestive for a cytoskeletal role of these structures in these cells. Since lens fibers do not divide anymore and gradually lose their nuclei, a role in cell division 27,28 and/or the anchoring of the nucleus ${ }^{29}$ has to be ruled out.

At least in these cells, that are the products of terminal lens 
cell differentiation, a support function for IF is suggested. In the epithelial cells covering the anterior side of the lens and that divide throughout the life span of the animal, the situation, however, may be completely different as compared to the fiber. Studies using cultured bovine epithelial lens cells $\mathrm{s}^{6}$ have shown that IF (also exclusively of the vimentin type) interact with microtubules. Therefore, when these cells are treated with colchicine the IF structures collapse and form a juxtanuclear aggregate, suggesting that no interaction of IF with the cellular membrane exits in the epithel ium. It furthermore suggests that in these cells IF do play a role in cell division as described for $\mathrm{PtK}_{2}$ cells by Aubin et al ${ }^{27}$.

This would mean, if in vitro studies reflect the in vivo situation, that during lens cell differentiation IF switch their function. Maisel and coworkers ${ }^{30-33}$ suggest a function of IF in lens accomodation next to a function in the maintainance of cell shape ${ }^{33}$.

As far as the interaction of other components with the plasma membranes is concerned the $\alpha A_{2}$ subunit of $\alpha$-crystallin has to be considered. Evidence is accumulating that this polypeptide attaches to heterologous and homologous membranes ${ }^{34,35}$. The following mechanism seems to be operative in the lens.

Initially newly synthesized $\alpha A_{2}$ subunits interact with the plasma membrane and only thereafter the $\alpha B_{2}$ chains join the complex to form the a-crystallin high molecular weight aggregate. This model is in full agreement with a proposal for the architecture of native $\alpha$-crystallin ${ }^{36}$ and studies on its biosynthesis in heterologous systems or oöcytes ${ }^{37}$ where it was found that a core of $\alpha A_{2}$ chains is required before $\alpha B_{2}$ chains can copolymerize to form the $\alpha$-aggregate.

Finally, high resolution electron microscopy provides some insight into the ultrastructure of the vimentin intermediate-sized filaments in lens fibers (see Fig 1b). The filament seems to be built up of three (or four) subfilaments called protofilaments by Maisel et al ${ }^{33}$. This finding is in fairly good agreement with the model proposed by Steinert et $a l^{38}$ for the subunit structure of IF in general. These authors suggest a trimeric aggregate of vimentin polypeptides as building blocks for mesenchymal IF. Observations in our laboratory (unpublished results) on the structure and molecular weight of soluble vimentin, newly synthesized, either incultured lens cells or in a reti- 
culocyte cell-free system, are in good agreement with this model. Further studies are needed to obtain a better insight into the assembly of IF and their association with cellular membranes. 


\section{REFERENCES}

1. Weihing, R.R. In: Meth. Achiev. Exp. Pathol. 8 (1979) pp 42 (G. Gabbiani, Ed.) Karger, Basel.

2. Lazarides, E., Nature 283 (1980) 249.

3. Franke, W.W., Schmid, E., Osborn, M. and Weber, K., Proc. Natl. Acad. Sci. USA 75 (1978) 5034.

4. Kibbelaar, M., Selten-Versteegen, A.M.E., Dunia, I., Benedetti, E.L. and Bloemendal, H., Eur. J. Biochem. 95 (1979) 543.

5. Bloemendal, H., Kibbelaar, M., Ramaekers, F.C.S., SeltenVersteegen, A.M.E., Dunia, I. and Benedetti, E.L. In: Prot. Biol. Fluids Proc. 26th Colloq. Brussels (H. Peeters, Ed.) Pergamon Press, Oxford (1979) 499.

6. Ramaekers, F.C.S., Osborn, M., Schmid, E., Weber, K., Bloemendal, H. and Franke, W.W., Exp. Cell Res. 127 (1980) 303.

7. Bloemendal, H., Ramaekers, F.C.S., Lenstra, J.A., Dodemont, H., Dunia, I. and Benedetti, E.L. In: Applied Methods in Oncology, Vol 3, The prediction value of short term screening tests in carcinogenecity evaluation (Williams, G.M., Kroes, R., Waayers, H.W. and Poll, v.d., K.W., Eds.) Elsevier Amsterdam (1980) pp 199.

8. Bloemendal, H., Lenstra, J.A., Dodemont, H., Ramaekers, F.C.S., Groeneveld, A.A., Dunia, I. and Benedetti, E.L., Exp. Eye Res. 31 (1980) 513.

9. Benedetti, E.L., Dunia, I., Ramaekers, F.C.S. and Kibbelaar, M.A. In: Molecular and Cellular Biology of the Lens, Chapter 4 ( $H$. Bloemendal, Ed.) Wiley and Sons, New York (1981) 137.

10. Franke, W.W., Weber, K., Osborn, M., Schmid, E. and Freudenstein, C., Exp. Cell Res. 116 (1978) 429.

11. Granger, B.L. and Lazarides, E., Cell 18 (1979) 1053.

12. Woodcock, C.L.F., J. Cell Biol. 85 (1980) 881.

13. Dunia, I., Sen Ghosh, C., Benedetti, E.L., Zweers, A. and Bloemendal, H., FEBS Letters 45 (1974) 139.

14. Lowry, 0.H., Rosebrough, N.J., Farr, A.L. and Randall, R.J., J. Biol. Chem. 193 (1951) 265.

15. Bloemendal, H., Schoenmakers, J., Zweers, A., Matze, R. and Benedetti, E.L., Biochim. Biophys. Acta 123 (1966) 217. 
16. Evans, M.I. and Lingrel, J.B., Biochemistry 8 (1969) 829

17. Pelham, H.R.B. and Jackson, R.J., Eur. J. Biochem. 67 (1976) 247.

18. Laemmli, U.K., Nature 227 (1970) 680.

19. Weber, K. and Osborn, M., J. Biol. Chem. 244 (1969) 4406.

20. Bonner, W.J. and Laskey, R.A., Eur. J. Biochem. 46 (1974) 83.

21. Berns, A.J.M. and Bloemendal, H. In: Enzymol. Methods 30 (1974) 313.

22. O'Farrell, P.H., J. Biol. Chem. 250 (1975) 4007.

23. Bloemendal, H., Zweers, A., Vermorken, F., Dunia, I. and Benedetti, E.L., Cell Diff. 1 (1972) 91.

24. Benedetti, E.L., Dunia, I. and Bloemendal, H., Proc. Nat1. Acad. Sci. USA 71 (1974) 5073.

25. Bloemendal, H., Vermorken, A.J.M., Kibbelaar, M., Dunia, I. and Benedetti, E.L., Exp. Eye Res. 24 (1977) 413.

26. Ungewicke11, E., Bennet, P.M., Calvert, R., Ohanian, V. and Gratzer, W.B., Nature 280 (1979) 811.

27. Aubin, J.E., Osborn, M., Franke, W.W. and Weber, K., Exp. Cell Res. 129 (1980) 149.

28. Blose, S.H., Proc. Nat1. Acad. Sci. USA 76 (1979) 3372.

29. Letho, V.-P., Virtanen, I. and Kurki, P., Nature 272 (1978) 175 .

30. Maisel, H., Lieska, N. and Bradley, R., Experientia 34 (1978) 352 .

31. Maisel, H. and Perry, M.M., Exp. Eye Res. 14 (1972) 7.

32. Lo, W.K. and Maisel, H., Ophthalm. Res. 11 (1979) 129.

33. Lieska, N., Maisel, H. and Romero-Herrera, A., Proc. Int. Soc. for Eye Research 1 (1980) 42.

34. Vermorken, A.J.M., Kibbelaar, M.A., Hilderink, J.M.H.C. and Bloemendal, H., Biochem. Biophys. Res. Commun. 88 (1979) 597.

35. Ramaekers, F.C.S., Selten-Versteegen, A.M.E. and Bloemendal, H., Biochim. Biophys. Acta 596 (1980) 57.

36. Bindels, J.G., Siezen, R.J. and Hoenders, H.J., Ophthal. Res. 11 (1979) 441 . 
37. Asselbergs, F.A.M., Koopmans, M., Venrooy van, W.J. and Bloemendal, H., Eur. J. Biochem. 91 (1978) 65.

38. Steinert, P.M., Idler, W.W. and Goldman, R.D., Proc. Nat1. Acad. Sci. USA 77 (1980) 4534. 
CHAPTER IV

CYTOSKELETAL AND CONTRACTILE STRUCTURES IN BOVINE LENS DIFFERENTIATION 
CHAPTER IV

\section{CYTOSKELETAL AND CONTRACTILE STRUCTURES IN \\ BOVINE LENS DIFFERENTIATION}

SUMMARY

Bovine lenses from animals of different ages were separated into two epithelial sections, a cortical region and the lens nucleus. Both the soluble and insoluble fractions of these sections were analyzed by SDS-gel electrophoretic techniques. A decrease in the amount of vimentin, the protein subunit of lens intermediate-sized filaments (IF), can be observed upon lens cell differentiation and aging. In particular in the nucleus of older lenses this phenomenon becomes obvious.

Furthermore, the amounts of globular-(G) and filamentous-(F) actin in the different stages of lens cell differentiation were quantitated using the DNase I-inhibition technique. A significant increase in the relative amount of F-actin is observed upon fiber cell formation. A slight increase of the total amount of actin as compared to the total amount of protein is observed when going from the central part of the lens epithelium to the epithelial cells in the elongation zone. In the fiber cells the amount of actin decreases when going from cortex to nucleus. A possible function of microfilament-assembly in the process of lens cell differentiation is suggested.

\section{INTROOUCTION}

Terminal differentiation of lens cells involves a number of subsequent changes in morphology and biochemical parameters of the lens epithelial cells 1,2 . During this process long lens fibers are formed and the cell volume increases dramatically (see Fig 1).

Furthermore, there is an onset of synthesis of typical lens proteins the crystallins. These proteins represent about $90 \%$ of the total protein in the lens ${ }^{2,3}$. The remaining $10 \%$ are mainly composed of membrane 


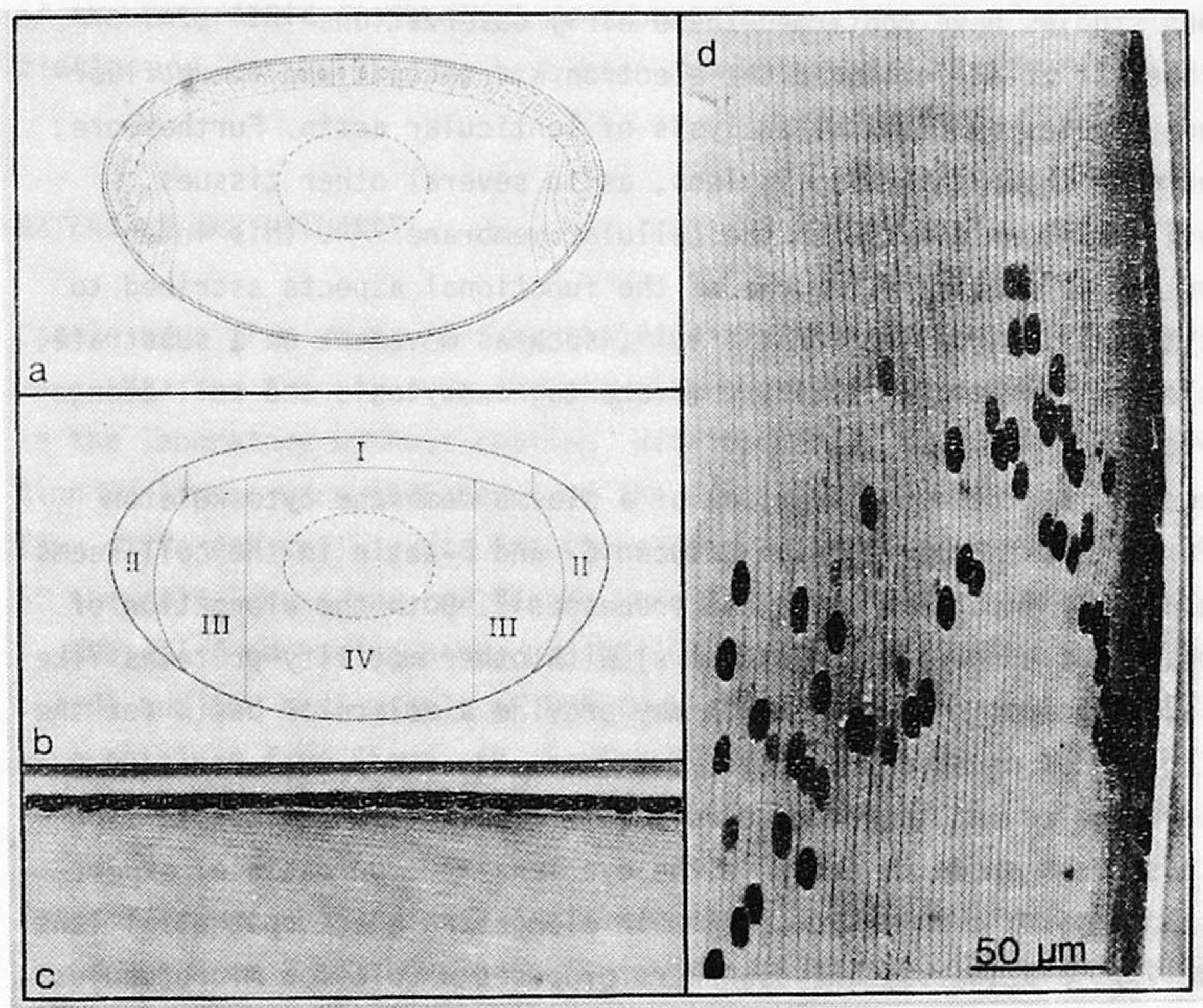

Fig 1 a. Schematic drawing of the lens indicating the different regions of lens development, as proposed by Papaconstantinoul. b. Schematic drawing showing the four regions of dissection used in this study.

c. Epithelial cells of the pre-elongation zone (Hematoxylin azophloxin-stain).

d. Cross-section of the bovine lens showing the region of cellular elongation (Hematoxylin azophloxin-stain). Courtesy Dept. of Cytology and Histology, University of Nijmegen.

and cytoskeletal proteins ${ }^{4}, 5$. Upon fibrogenesis, changes are observed in the protein patterns of the cellular membranes from epithelium and fiber cells $\mathrm{s}^{6,7}$.

Recently, investigations in our laboratory have concentrated on a possible function of the lenticular cytoskeletons in the process of lens differentiation. The presence of microfilament-like structures in membrane preparations of bovine calf lens has already been shown in the electron microscope by Bloemendal et al in $1972^{8}$. Thereafter 
various studies have confirmed these early observations ${ }^{4,9-14}$.

Kibbelaar et al ${ }^{9}$ extended the electron microscopic and immunofluorescence studies by chemical analysis of lenticular actin. Furthermore, it could be shown that also in lens, as in several other tissues, microfilaments interact with the cellular membrane ${ }^{7}, 15$. This interaction may be necessary for one of the functional aspects ascribed to the cytoskeleton: cellular motility ${ }^{16}$, such as movement on a substrate, cytoplasmic streaming, saltitary movements, exocytosis and cell elonga$\operatorname{tion}^{17}$.

However, next to the formation of a plasma membrane cytoskeleton complex, a dynamic equilibrium between G- and F-actin in the cell seems to be equally important for these processes ${ }^{18}$. Both the elongation of microfilament bundles (stress fibers) with other motility proteins like myosin, tropomyosin and a-actinin may provide a molecular basis for the driving forces necessary in cell movements.

Microtubules and intermediate-sized filaments of the vimentin-type have also been shown to occur in the eye lens ${ }^{4,19}$. On basis of experiments using colchicine 20 and studies in elongating chick epithelial lens cells ${ }^{21,22}$ Piatigorsky and coworkers proposed a role for microtubules in lens differentiation. In a recent paper, however, Beebe et a ${ }^{23}$ showed, that these chicken epithelial lens cells elongate in culture despite the fact that their microtubule organization had been destroyed by nocodazole. Mousa and Trevithick ${ }^{24}$ have reported an inhibitory effect of the cytochalasins $B$ and $D$ on rat lens cell differentiation in vitro. These experiments, together with others ${ }^{25}$ suggest an important role of microfilaments in lens cell elongation (differentiation) in a way comparable to axon-elongation ${ }^{26}$. Mousa and Trevithick ${ }^{12}$ have quantitated the total amount of actin in various in vivo stages of rat lens differentiation by means of gel electrophoretic techniques. The highest amount of actin was found in the lens epithelial cells and decreased when going from periphery to the nucleus. Also the ratio between $B$ - and $\gamma$-actin appeared to change.

In this chapter we show that differentiation of calf lens cells is accompanied by an increase in microfilament assembly suggesting a shift of G-actin to F-actin during elongation, rather than a change in the total amount of actin. Furthermore, changes in the amount 
of the intermediate-sized filament protein as a result of differentiation and lens cell aging have been demonstrated.

\section{MATERIALS AND METHODS}

Cattle eyes from young (3-6 months) and old animals (about 4 years) were obtained freshly from the slaughterhouse and were transported to the laboratory without cooling. Within half an hour after dissection the lenses were isolated from the eyes and separated into the four different cell lysate fractions (see below). The average weights of the calf lenses and cow lenses were $1.5 \mathrm{~g}$ and $2.6 \mathrm{~g}$, respectively.

DNase I from bovine pancreas (DN-100, 1505 Kunitz units per mg solid) and the sodium salt of DNA from calf thymus (type I, D11501) were obtained from Sigma, St. Louis, USA.

Guanidinium hydrochloride was obtained from Merck, Darmstadt.

Preparation of cell-lysates for the actin-quantification assay

Lenses from 3 months-old calfs were sectioned at room temperature into four fractions. These fractions included:

1. central region of the epithelial cells

2. germinative region and the region of cellular elongation

3 . the elongated fiber cells in the superficial cortical region

4. fiber cells in the deeper layers surrounding the nucleus

The epithelial fractions were carefully excised from the cortex using dissecting scissors. The cortical fractions were obtained by using a metal tube (diameter 1.2) which separated young and old fibers. The subsequent fractions were homogenized with a Dounce $B$ homogenizer in lysis buffer, containing $2 \mathrm{mM}$ phosphate buffer (pH 7.6), $150 \mathrm{mM}$ $\mathrm{NaCl}, 0.2 \mathrm{mM} \mathrm{ATP}, 2 \mathrm{mM} \mathrm{MgCl}_{2}, 0.2 \mathrm{mM} \mathrm{1,4}$ dithioerythritol (DTE), $0.5 \%$ Triton $\mathrm{X}-100$ and $1 \mathrm{mM}$ phenyl-methanesulfonylfluoride (PMSF).

\section{Actin assay}

Globular and filamentous actin concentrations were estimated as described previously by $B 1$ ikstad et $a \ell^{27}$ with slight modifications. After centrifugation of the tissue homogenate ( $5^{\prime}$ at $10,000 \times \mathrm{g}$ ) the super- 
natant fractions were used for the estimation of the globular actin. The amounts of tissue and lysis buffer were chosen in order to ensure a $30-70 \%$ inhibition of the DNase I activity. In contrast to the method of Blikstad et al ${ }^{27}$ no $\mathrm{Ca}^{++}$- and $\mathrm{Mg}^{++}$-ions were added to the DNA stocksolution, since we occasionally observed DNA-breadown in the presence of bivalent ions. This modification required adjustment of the DNAsubstrate buffer to $5 \mathrm{mM} \mathrm{MgSO}_{4}, 2 \mathrm{mM} \mathrm{CaCl}_{2}$ and $0.1 \mathrm{M} \mathrm{Tris/HCl}(\mathrm{pH} \mathrm{7.5)}$.

In the actin assay, $300 \mu 1$ DNA-substrate buffer and $50 \mu 1$ DNA-stock solution $(500 \mu \mathrm{g} / \mathrm{ml})$ were mixed with $5 \mu \mathrm{l}$ DNase I stock solution (10 $\mu \mathrm{g} / \mathrm{ml})$. Hydrolysis of DNA was followed by hyperchromicity measurement at $260 \mathrm{~nm}$, using a Zeiss M4Q III spectrophotometer. The slope of the linear part of the absorbance at $260 \mathrm{~nm}$ is directly proportional to the amount of enzyme added (see Fig 2a). For the determination of inhibitor (actin) activity $5 \mu 1$ DNase I stock solution is mixed with 1-5 $\mu 1$ cell lysate, chosen to give about $50 \%$ inhibition of the DNase I. The standard amount of DNase I gave an increase over the linear part of the hyperchromicity curve of 0.012-0.014 absorbancy units per minute (see Fig 2b). The decrease in DNase activity is directly proportional to the amount of monomeric actin added, at least in the region between $30-70 \%$ inhibition. Profilactin and G-actin can be analyzed by mixing an aliquot of the cell lysates with DNase I without GuHCl pretreatment, while F-actin must be dissociated to monomeric actin with GuHCl prior to the inhibition assay (see Fig 2b).

Complete inhibition of $1 \mu \mathrm{g}$ of pure DNase I should be obtained with $1.35 \mu \mathrm{g}$ of pure actin. For calculation of the absolute amount of actin in the cell lysates directly from the DNase I inhibition assay, the results from $B 1$ ikstad et al were adopted ${ }^{27}$. These workers estimated that the DNase I used contained about $0.7 \mu \mathrm{g}$ of active DNase I per $\mu \mathrm{g}$ of protein.

The total amount of protein in the cell lysate, was determined according to Lowry et al ${ }^{28}$ with the modification that $0.5 \%$ SDS was used to prevent precipitation after addition of the Folin reagent due to the presence of Triton $X-100$ in the cell lysate ${ }^{29}$.

\section{Polyacrylamide gel electrophoresis}

Lenses were sectioned as described for the actin assay. 
From the fetal lens ( 6 months) first the whole epithelium was dissected and the cortex fractionated as follows. The lens was first frozen to $-20^{\circ} \mathrm{C}$ and after thawing the outer layers of the lens were scraped off, thus giving four fractions. Fraction I represents the outermost, fraction IV the innermost fiber cells.

The cell lysates used for the gel electrophoresis were prepared with the same lysis buffer as used in the actin assay. After homogenizing and centrifugation $\left(5^{\prime}, 10,000 \times g\right)$ the supernatant and the pellet fractions were used separately for protein analysis.

Sodium dodecyl sulphate-polyacrylamide gel electrophoresis was performed according to Laemmli $i^{30}$ with the modification that a slab gel instead of gel rods was used. The gel was $12 \mathrm{~cm}$ long and contained $13 \%$ acrylamide, $0.4 \%$ methylene-bisarcrylamide and $0.1 \%$ sodium dodecyl sulphate. In this method a stacking gel was applied. Staining and destaining were performed as described by Weber and 0sborn ${ }^{31}$.

Two-dimensional gel electrophoresis was performed according to $0^{\prime}$ Farrel1 32 .

\section{RESULTS}

\section{Sectioning of the lens}

In our experiments the lens was sectioned into four fractions (see Fig $1 \mathrm{a}$ and b) representing the following regions:

1. central region of the epithelial cells

2. germinative region and the region of cellular elongation

3. young fiber cells

4. old fiber cells and the nucleus

In Fig 1c, cells in the central epithelial region are depicted.

Fig ld shows a detail of a section through a calf lens in the equatorial zone. It can be seen that from the epithelial cells the lens fibers arise.

\section{Actin assay}

The ratio between filamentous and globular actin ( $F / G$ ratio) was determined as described in the method section.

First the increase in hyperchromicity after mixing known amounts 
of DNA and DNase I is followed at $260 \mathrm{~nm}$. The slope of the linear part is directly proportional to the amount of enzyme added (Fig 2a). The amount of G-actin is determined by mixing an aliquot of a cell lysate with DNase I. From the resulting inhibition of the DNase I action the amount of G-actin is calculated. To determine the amount of F-actin, GuHCl is mixed with the cell lysate prior to the actin assay. The increased inhibition relative to the DNase I inhibition obtained without GuHCl addition, gives the amount of F-actin in the cell lysate. Examples of such inhibition curves are presented in Fig $2 b$. The results of actin assays in the various lens sections are presented in Table I and Fig 2c.
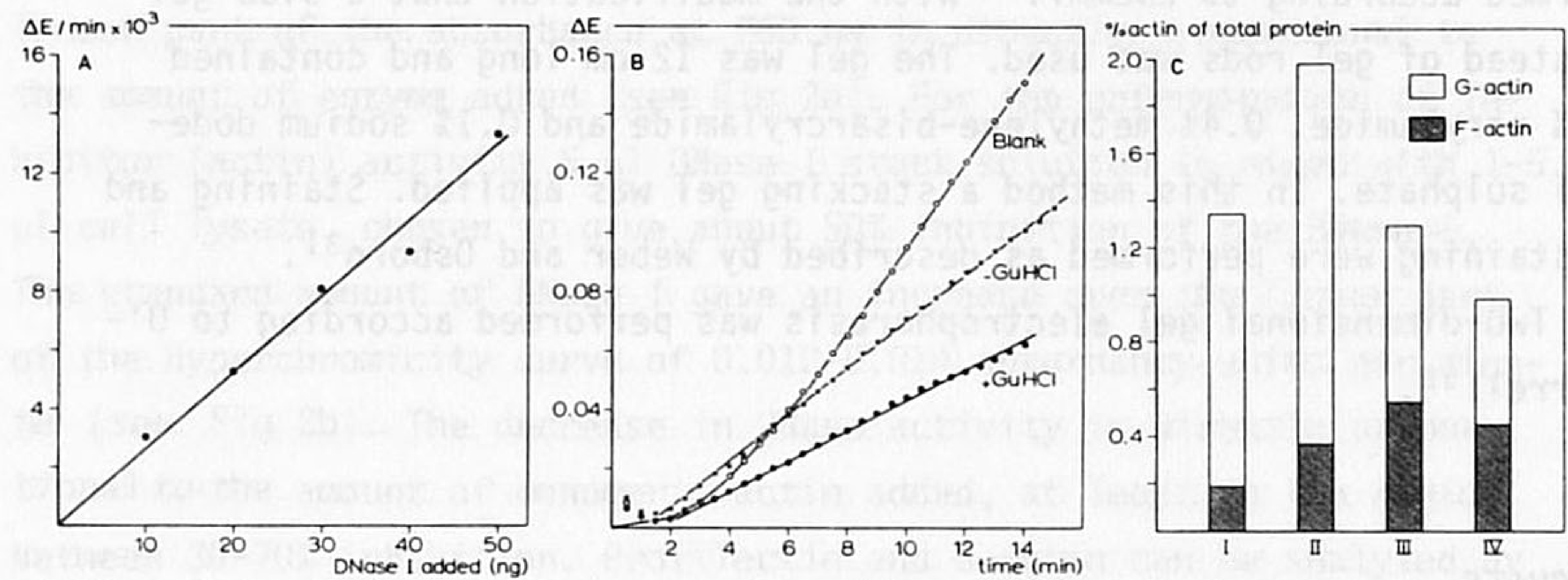

Fig 2 a. Standard curve for the estimation of DNase I-activity in the actin assay.

b. Curves showing the DNase I-inhibition as a result of addition of cell lysates from calf lens cortex to the DNA-DNase I-incubation mixture. The effect of guanidinium hydrochloride (GuHCl) when added to the cell lysate becomes clearly visible. Blank incubation: without cell lysate.

c. Histograms showing the amounts of total, globular and filamentous actin in the four different regions of the lens (see Fig lb and Table I).

To determine the $F / G$ ratio in a cell lysate, at least two different volumes of the cell lysates were used. Only those volumes which showed DNase I inhibition of $30-70 \%$ were used to establish the mean F/G value of the cell lysate. The $F / G$ ratio of a particular lens fraction and the standard deviation were determined by using the mean $F / G$ values of at least four different cell lysates from this particular fraction.

The results presented in Table I indicate a significant increase 
Table I DISTRIBUTION OF FILAMENTOUS AND GLOBULAR ACTIN IN THE DIFFERENT REGIONS OF THE CALF LENS

\begin{tabular}{lcccc}
\hline & $\%$ F-actin & $\%$ G-actin & F/G ratio \\
$\begin{array}{l}\text { Central region of the epithelial } \\
\text { cells }\end{array}$ & $13 \pm 8$ & $87 \pm 8$ & $0.15 \pm 0.10$ \\
$\begin{array}{l}\text { Germinative region and the region } \\
\text { of cellular elongation }\end{array}$ & $22 \pm 7$ & $78 \pm 7$ & $0.22 \pm 0.09$ \\
$\begin{array}{l}\text { Young fiber cells } \\
\text { 0ld fiber cells and the nucleus }\end{array}$ & $40 \pm 7$ & $60 \pm 7$ & $0.66 \pm 0.18$ \\
\end{tabular}

of the $F / G$ ratio during the process of lens differentiation. The increase is most pronounced in those regions where the elongation takes place $(0.22$ to 0.66 in going from the germinative to the region with young fiber cells).

Table II shows the amounts of actin as compared to the total protein amounts in the different lens sections. It can be seen that the amount of actin is maximal in the germinative region and the region of cellular elongation. In the elongation process thereafter the amount of actin decreases.

Table II RELATIVE AMOUNTS OF ACTIN AS COMPARED TO THE TOTAL PROTEIN AMOUNTS IN THE DIFFERENT REGIONS OF THE CALF LENS

\begin{tabular}{lccc}
\hline & $\%$ total actin & $\%$ F-actin & $\%$ G-actin \\
$\begin{array}{l}\text { Central region of the } \\
\text { epithelial cells }\end{array}$ & $1.37 \pm 0.34$ & $0.18 \pm 0.05$ & $1.19 \pm 0.30$ \\
$\begin{array}{l}\text { Germinative region and } \\
\text { the region of cellular } \\
\text { elongation }\end{array}$ & $1.98 \pm 0.49$ & $0.34 \pm 0.09$ & $1.54 \pm 0.36$ \\
$\begin{array}{l}\text { Young fiber cells } \\
\text { Old fiber cells and }\end{array}$ & $1.30 \pm 0.32$ & $0.52 \pm 0.13$ & $0.78 \pm 0.20$ \\
nucleus & $0.95 \pm 0.24$ & $0.44 \pm 0.11$ & $0.51 \pm 0.13$ \\
\hline
\end{tabular}


Protein analysis. Changes in the protein pattern of the lenticular cytosekeleton during differentiation

The cell lysates were seperated into a soluble and insoluble fraction by centrifugation ( 5 min at $10,000 \times \mathrm{g}$ ). Both fractions of all the lens sections were analyzed by SDS slab gel electrophoresis (Fig 3).

The increase of actin filaments during differentiation of calf lens epithelium, as determined by the actin assay, is substantiated by the protein patterns of the sections after SDS gel electrophoresis. The actin band in the insoluble cortical sections (Fig 3 , lanes 8 and 9) is stronger than in the insoluble epithelium sections (Fig 3, lane 6 and 7), indicating that a higher amount of actin, insoluble in lysis buffer, is present in the cortex. The main cytoskeletal constituents (vimentin and actin) were identified and characterized by $2 \mathrm{D}$-gel electrophoresis.

Fig 4 depicts a detail of a 2D-gel, showing the relative amounts of vimentin (V), $\beta$ - and $\gamma$-actin (A) and $\alpha$-actinin (100 kD). This latter protein is only observed in the insoluble fractions of the fibers (see Fig 3, lane 8 and 9, arrow). The intermediate-sized filament protein represents the main constituent in this fraction. Furthermore it can be seen that the ratio of $\beta / \gamma$-actin is in favor of $\gamma$-actin.

Vimentin is present in the epithelium and the peripheral fibers (see Fig 3, lanes $6-8$ ). The identity of this protein in the epithelium was also confirmed by 2D-gel electrophoresis (results not shown). When comparing the protein bands in the $57 \mathrm{kD}$-region of the nuclear fibers with the younger, less differentiated, fractions, it becomes obvious that the vimentin band, characteristic for the epithelial cells, is absent in the nuclear fibers. In this section, however, two other bands are seen in the $57 \mathrm{kD}$ region of the gel. They increase in intensity when going from the epithelium to the nucleus. From Fig 4 it can, however, be concluded that all three bands migrate together in the isofocusing direction. Also in the soluble fraction a weak band co-migrating with vimentin is seen (e.g. Fig 3 , lane 2).

In this context it should be mentioned that the changes in the crystallin pattern also occur during differentiation. The changes in the soluble fractions observed are mainly an increase in $\mathrm{BB}_{1 \mathrm{~b}}$ (lane 5 , arrow) when going from the epithelium to the nucleus. Examination of the 
insoluble fraction reveals two features:

1. in the epithelium, next to vimentin, mainly two $\beta$-crystallins remain attached to the membrane-cytoskeleton complex (see Fig 3, lanes 6 and 7) while almost no $\alpha$-crystallin is present

2 . in contrast, $\beta$-crystallins are almost absent in the insoluble fractions of the fibers (see Fig 3, lanes 8 and 9). Here, however, $\alpha$-crystallin becomes the main protein constituent. In the oldest fibers (lane 9) both $\alpha A$ and $\alpha B$ are present, in equal amounts while in the peripheral fibers $\alpha A$ represents the main $\alpha$-crystallin subunit (see lane 8. The doublet may be due to the presence of a $\gamma$ crystallin chain.).

Aging

Fiber cells are continuously laid down on the superficial part of the lens during the life-span of the animal. Since all lens cells remain intact, fibers in the nuclear region represent older cells than those in the cortex. Therefore we wondered whether changes in the patterns of subsequent stages of differentiation could be explained as an aging phenomenon. For this purpose we also analyzed the protein patterns of the cell lysates from the fetal calf lenses and 4 years old cow lenses (see Figs 5 and 6 ).

In the preparation of the fetal calf lens cell lysates the epitheliumwas not further sectioned. Neither could the soluble and the insoluble parts of the epithelium be separated. However, the cortex was devided into four regions by scraping the cortex upon thawing of the frozen lens.

From the protein patterns, shown in Fig 5 , it can be seen that in the epithelium and cortex fractions from fetal lenses, vimentin is present in a rather high concentration (lanes 7-10). The same holds true for actin, which is also present in the soluble fraction (lanes 3-6). When going from the epithelium to the innerside of the lens, two bands in the insoluble fractions with a mol weight slightly lower than vimentin occur and increase in intensity. Whether these are breakdown products of the intermediate filament protein remains to be established. Furthermore, only in the insoluble fraction a band is observed in the $47 \mathrm{kD}$ region, which probably represents a hitherto un- 





Fig 3 SDS-gel electrophoresis patterns of the soluble proteins (crystallins) and the insoluble fractions from the four different regions of 3-6 months-old calf lenses.

( 1 and 10) Marker proteins: $\alpha$-crystallin (20,000 D), ovalbumin $(45,000$ D), bovine serum albumin $(68,000 \mathrm{D})$ and phosphorylase A $(93,000 \mathrm{D})$.

(2-5) Soluble proteins from regions I-IV, respectively (see Fig $1 b$, arrow indicates $\mathrm{BB} 1 \mathrm{~b})$.

(6-10) The membrane cytoskeleton complex of regions I-IV, respectively ( $V=$ vimentin; $A=$ actin, arrow indicates $\alpha$-actinin).

Fig 4 Two-dimensional gel electrophoretic analysis (detail) of the main cytoskeletal proteins occurring in bovine lens fibers (3-6 months

old animals).

Fig 5 SDS-gel electrophoretic analysis of embryonic calf lens proteins.

(1) Total protein pattern of unfractionated epithelial cell-layer.

$(2,11)$ Marker proteins (compare legend Fig 3).

(3-6) Soluble proteins from four fiber regions of the embryonic lens. Lane 3 represents the outermost fiber layer, while lane 6 contains proteins from the innermost fibers.

(7-10) Insoluble proteins from the regions as in lanes 3-6 (V=vimentin; $A=$ actin).

(12) As markers intrinic membrane proteins from calf lens were run in parallel. The main band MP26 and the less strong MP34 band are clearly visualized.

Fig 6 SDS-gel electrophoretic analysis of lens proteins from cow (about 4 years old).

(1-4) Soluble proteins from lens regions I-IV, respectively (compare legend to Fig 3 and see Fig 1b).

(5-8) Insoluble fractions of regions I-IV, respectively (V=vimentin).

(9) Marker proteins as in Fig 3. 
identified cytoskeletal constituent ${ }^{33}$.

In lenses from 4 years-old cows a striking phenomenon can be observed. When comparing the protein patterns of the insoluble fractions of epithelium, cortex and nucleus (Fig 6, lanes 5-8) it is clear that in the old fiber fractions vimentin is absent. In the epithelial fraction an appreciable concentration of this intermediate filament protein is found as is the case with two $\beta$-crystallin polypeptides in the region of cellular elongation (lane 6 ). The latter protein pattern is comparable to that of 3 months-old calf lenses.

\section{DISCUSSION}

In the underlying study we have tried to find correlations between changes occurring in cytoskeletal structures and lens cell differentiation. Using the DNase I inhibition assay amounts of F- and G-actin could be measured in different regions of the lens. An active role of microfilaments in the process of lens cell elongation, which occurs in the equatorial zone, is concluded from the following results:

1. the ratio between $\mathrm{F}$-actin and $\mathrm{G}$-actin increases during the process of terminal differentiation (see Table I)

2. the amount of F-actin (as compared to the total amount of protein present in the cells) is almost doubled when epithelial cells from the central region and of the region of cellular elongation are compared (see Table II)

3. the total amount of actin seems to decrease already during the elongation process (see Table II), whereas the amount of F-actin still increases and diminishes only after the cells have differentiated.

These results suggest that the process of microfilament assembly during lens cell differentiation is a factor in cell elongation.

In vitro studies (see Chapter V) give similar results. When te cells elongate in culture a gradual increase in filamentous actin in the cells takes place as demonstrated by several techniques including the actin assay, electron microscopy, indirect immunoflores- 
cence studies and gel electrophoretic procedures.

When young and old lenses or lens sections are compared, it becomes obvious that as a result of aging vimentin decreases in concentration which in the nucleus of cow lenses results in the absence of this protein. The gel electrophoretic data nicely correlate to immunofluorescence and electron microscopic studies described earlier ${ }^{4}$. Furthermore, it seems that this intermediate filament protein is gradually broken down as a result of proteolytic activity in the lens ${ }^{34}$.

As a result two or three separate bands often migrate in the vimentin range, both on isoelectrofocusing and SDS-gels. A possible postsynthetic modification of the native vimentin molecule should also be kept in mind since in Fig 3 (lanes 8 and 9), also a band with a slightly higher molecular weight than native vimentin, but co-migrating with vimentin on the isofocusing gel is seen.

It has been reported previously that crystallins also interact with the cytoskeleton-plasma membrane complex ${ }^{35,36}$. However, our results show a specific interaction of $\alpha$-crystallin with this complex only in the mature fibers. Strikingly in the epithelial cells only B-crystallins interact with the cytoskeleton-membrane complex. It seems that the binding possibilities of crystallins change during differentiation and/or aging. The molecular basis of this phenomenon is still unclear and will be examined in further studies. Investigations still in progress also include two-dimensional gel electrophoretic analys is of the cytoskeletons in several stages of differentiation. In this way we hope to get an idea about interactions between the crystallins and the cytoskeletal and contractile proteins that are involved in lens cell differentiation. 


\section{REFERENCES}

1. Papaconstantinou, J., Science 156 (1967) 338.

2. Bloemendal, H., Science 197 (1977) 127.

3. Harding, J.J. and Dilley, K.J., Exp. Eye Res. 22 (1976) 1.

4. Ramaekers, F.C.S., Osborn, M., Schmid, E., Weber, K., Bloemendal, H. and Franke, W.W., Exp. Cell Res. 127 (1980) 309.

5. Kibbelaar, M.A. and Bloemendal, H., Exp. Eye Res. 29 (1979) 679.

6. Vermorken, A.J.M., Hilderink, J.M.H.C., Dunia, I., Benedetti, E.L. and Bloemendal, H., FEBS Lett. 83 (1977) 301.

7. Benedetti, E.L., Dunia, I., Bentzel, C.J., Vermorken, A.J.M., Kibbelaar, M.A. and Bloemendal, H., Biochim. Biophys. Acta 457 (1976) 353.

8. Bloemenda1, H., Zweers, A., Vermorken, F., Dunia, I. and Benedetti, E.L., Cel1 Diff. 1 (1972) 91.

9. Kibbelaar, M.A., Selten-Versteegen, A.M.E., Dunia, I., Benedetti, E.L. and Bloemendal, H., Eur. J. Biochem. 95 (1979) 543.

10. Lonchampt, M-0., Laurent, M., Courtois, Y., Trenchev, P. and Hughes, R.C., Exp. Eye Res. 23 (1976) 505.

11. Drenckhahn, D. and Gröschel-Stewart, U., Cell Tiss. Res. 181 (1977) 493.

12. Mousa, G.Y. and Trevithick, J.R., Exp. Eye Res. 29 (1979) 71.

13. Rafferty, N.S. and Goossens, W., Exp. Eye Res. 26 (1978) 177.

14. Kibbelaar, M.A., Ramaekers, F.C.S., Ringens, P.J., SeltenVersteegen, A.M.E., Poels, L.G., Jap, P.H.K. Rossum van, A.L., Feltkamp, T.E.W. and Bloemendal, H., Nature 285 (1980) 506.

15. Ramaekers, F.C.S., Selten-Versteegen, A.M.E., Dunia, I., Benedetti, E.L. and Bloemendal, H., Proc. Nat1. Acad. Sci. USA 77 (1980) 725.

16. Clark, M. and Spudich, J., Ann. Rev. Biochem. 46 (1977) 797.

17. Goldman, R., Pollard, T. and Rosenbaum, J. (Eds.), Cell Motility, Books, A-C., Vol. 3, Cold Spring Harbor Conferences on Cell Proliferation, Cold Spring Harbor Laboratory (1976).

18. Lindberg, U., Carlsson, L., Markey, F. and Nyström, L.E., Meth. Achiev. Exp. Pathol. 8 (1979) 143.

19. Piatigorsky, J., Ann. N.Y. Acad. Sci. 253 (1975) 333. 
20. Piatigorsky, J., Rothschild, S.S. and Wollberg, M., Proc. Nat1. Acad. Sci. USA 70 (1973) 1195.

21. Piatigorsky, J., Rothschild, S.S. and Milstone, L.M., Develop. Biol. 34 (1973) 334.

22. Piatigorsky, J., Webster de, M.F. and Craig, S.P., Develop. Biol. 27 (1972) 176.

23. Beebe, D.C., Feagans, D.E., Blanchette-Mackie, E.J. and Nau, M.E., Science 206 (1979) 836.

24. Mousa, G.Y. and Trevithick, J.R., Develop. Biol. 60 (1977) 14.

25. Ramaekers, F.C.S., Hukkelhoven, M.W.A.C., Groeneveld, A. and Bloemendal, H., Ophthal. Res. 11 (1980) 283.

26. Wessels, N.K., Spooner, B.S., Ash, J.F., Bradley, M.0., Luduena, M.A., Taylor, E.L., Wrenn, J.T. and Yamada, K.M., Science 171 (1971) 135.

27. Blikstad, I., Markey, F., Carlsson, L., Persson, T. and Lindberg, U., Cell 15 (1978) 135.

28. Lowry, 0.H., Rosebrough, N.J., Farr, A.L. and Randa11, R.J., J. Biol. Chem. 193 (1951) 265.

29. Dulley, J.R. and Grieve, P.A., Analytical Biochem. 64 (1975) 136.

30. Laemmli, U.K., Nature 227 (1970) 680.

31. Weber, K. and Osborn, M., J. Biol. Chem. 244 (1969) 4406.

32. O'Farrell, P.H., J. Biol. Chem. 250 (1975) 4007.

33. Ungewicke11, E., Bennett, P.M., Calvert, R., Ohanian, V. and Gratzer, W.B., Nature 280 (1979) 811.

34. Lazarides, E., Nature 283 (1980) 249.

35. Bloemendal, H., Kibbelaar, M.A., Ramaekers, F.C.S., SeltenVersteegen, A.M.E., Dunia, I. and Benedetti, E.L. In: Protides of the Biological Fluids, Proceedings of the Twenty-sixth colloquium (Peeters, H. Ed.) Pergamon Press, Oxford-New York (1979) pp 499.

36. Ramaekers, F.C.S., Selten-Versteegen, A.M.E. and Bloemendal, H., Biochim. Biophys. Acta 596 (1980) 57. 


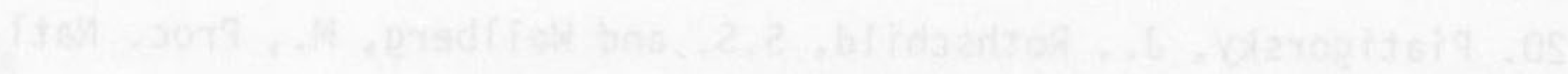

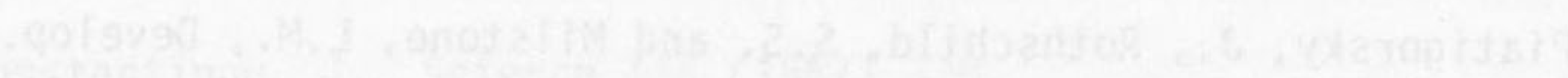

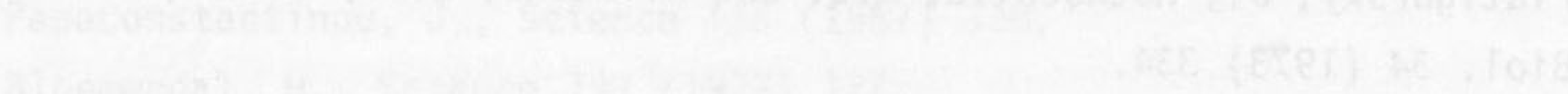

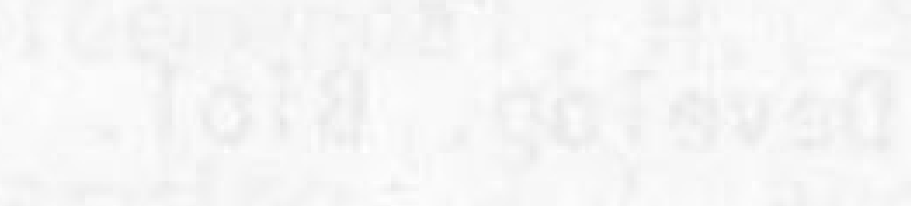


CHAPTER V

MICROFILAMENT ASSEMBLY DURING LENS CELL ELONGATION IN VITRO 
CHAPTER V

MICROFILAMENT ASSEMBLY OURING LENS CELL ELONGATION IN VITRO

SUMMARY

Bovine epitheloid lens cells can be kept in culture for one year. During subculturing a gradual process of cell elongation is observed. The following lines of evidence are presented to show that microfilament assembly plays a role in this process.

1. During lens cell elongation significant changes are observed in the structural organization of the microfilaments. Using the indirect immunofluorescence technique a change in actin organization from a random distribution in cuboidal cells to extensive parallel arrays of stress fibers in elongated cells is seen. Furthermore, a transiently formed structure is observed consisting of regular polygonal networks of actin fibers. Quantitation of these actin networks clearly shows that they are temporary structures occurring in cells just before elongation.

2. Two-dimensional gel electrophoretic analysis of the newly made cytoskeletal proteins shows a drastic decrease in tubulin synthesis, indicating that a role of microtubules in cell elongation is unlikely.

3. On the other hand gel electrophoretic analyses of the cytoskeletal preparations reveal an increasing amount of $\beta$-actin and myosin in these fractions, while the incorporation of vimentin decreases. This indicates that the former two proteins may be responsible for the formation of the strong parallel arrays of stress fibers. Quantitative estimations of G- and F-actin indicate a gradual increase in filamentous actin, while the total amount of actin is doubled.

4. After treatment of the cells with cytochalasin B a drastic effect is seen on the elongated cells as compared to cuboidal cells. After withdrawal of the drug only young cells regain their original shape. This indicates that the cell structure of elongated cells depends strongly on actin filaments.

5. Elongation can be induced by incubation with dexamethasone or 
or an extract of the neural retina. During this process also parallel arrays of stress fibers form in the elongated cells within $48 \mathrm{~h}$ while cytochalasin B inhibits the process.

\section{INTRODUCTION}

Bovine epithelial cells in culture elongate spontaneously upon aging ${ }^{1}{ }^{2}$. The cells change from a cuboidal shape to long, fiberlike cells. This phenomenon can also be induced by dexamethasone ${ }^{3}$ or by a soluble extract of the neural retina ${ }^{4}$. Elongation of chick embryo lens epithelial cells in vitro can be induced by insulin or under certain growth medium conditions ${ }^{5}$. It has been concluded that this process reflects as far as morphology is concerned in vivo differentiation ${ }^{6}$.

It is now generally accepted that cell shape changes, as well as other forms of cellular motility processes, involve a redistribution of the intracellular cytoskeletal structures ${ }^{7}$. For example, in chicken lens Piatigorsky and coworkers ${ }^{8}$ found a reorganization of microtubules in elongating epithelial cells. Furthermore they were able to show that the process of elongation could be inhibited by colchicine. However, since the amount of microtubules in these cells is not impressive and no increase in tubulin synthesis was observed a secondary effect of this protein in the elongation process has to be taken into consideration.

Beebe et al $^{9}$ demonstrated that the presence of intact microtubules is not a prerequisite for lens cell elongation. Since Mousa and Trevithick ${ }^{10}$ found that elongation (differentiation) of cultured rat epithelial cells is inhibited by cytochalasins $B$ and $D$ the question arises as to whether microtubules or microfilaments play a major role in the morphological changes that occur in elongating epithelial lens cells.

In a recent investigation (see Chapter II and ref 11 ) we observed the presence of cytoskeletal structures (microfilaments, microtubules and intermediate-sized filaments) in bovine lens cells by means of immunofluorescence studies, demonstrating that the main constituents of these structures are actin, myosin, $\alpha$-actinin, tubulin and vimentin. 
Further identification was achieved by means of transmission electronmicroscopy and gel electrophoretic techniques.

In the present study we shall provide evidence that in cultured bovine lens cells the assembly of microfilaments and their final organization in stress fibers interacting with the cellular membrane plays an important role in the in vitro elongation of these cells. Therefore the system is a suitable model for the study of microfilament assembly in general.

MATERIALS AND METHODS

Materials

L- $\left[{ }^{35} \mathrm{~S}\right]$-methionine (specific activity $190 \mathrm{Ci} / \mathrm{mMol}$ ) was obtained from the Radiochemical Centre, Amersham, England.

New-born calf serum was purchased from Flow Laboratories, Scotland.

DNAse I was bought from Sigma.

Fluorescein conjugated goat anti rabbit $\gamma$-globulins were purchased from Miles \& Co (Kankakee, I1l.) and used at $1 \mathrm{mg} / \mathrm{ml}$ in phosphate-buffered saline (PBS).

Cytochalasin B was obtained from Calbiochem, Basel, Switzerland and stored as stock solutions $(10 \mathrm{mg} / \mathrm{ml})$ in DMSO.

Colchicine was obtained from Merck (Darmstadt).

\section{Cell culture}

Bovine epithelial lens cells were cultured mainly as described earlierl.

Calf eyes were obtained from the slaughterhouse and kept on ice. They were washed with distilled water and opened at the lateral side to remove the lenses. The lens capsule, with adhering epithelial cells, was isolated and spread out on the bottom of plastic culture flasks. The capsules were allowed to stick to the surface of the flask for 30 $\min$ at $37^{\circ} \mathrm{C}$. Then the tissue culture medium, consisting of TC 199 , $0.33 \%$ lactalbumin hydrolysate in Hank's solution $(1: 2 \mathrm{v} / \mathrm{v})$ with $10 \%$ newborn calf serum, penicillin (100 i.U. per $\mathrm{ml}$ ) and streptomycin $(100 \mu \mathrm{g} / \mathrm{ml})$ was added carefully. After one week cells grew from the capsule on the surface of the flask. Cells were subcultured by treat- 
ment of the cells $0.35 \%$ trypsin in $\mathrm{Ca}^{2+}$ - and $\mathrm{Mg}^{2+}$-free tyrode-solution. Routine transfers were done weekly at a split ratio $1: 4$.

Actin antibodies and indirect immunofluorescence microscopy

Actin antibodies, kindly provided by Drs M. Osborn and K. Weber, were raised in rabbits against denaturated chicken gizzard actin ${ }^{12}$. They were made monospecific by affinity chromatography on homogeneous monomeric pig brain actin covalently bound to Sepharose $4 B$. The antibody was used at $50 \mathrm{mg} / \mathrm{ml}$ in PBS.

Cells grown on coverslips were treated with methanol and acetone at $-20^{\circ} \mathrm{C}$ air-dried and then the first antibody (anti-actin) was added and the coverslips incubated for 40 minutes at $37^{\circ} \mathrm{C}$. After washing with PBS the fluorescein-labeled second antibody was added and the coverslips held for a further 40 minutes at $37^{\circ} \mathrm{C}$. After a second series of washes with PBS the coverslips were mounted with Elvanol on microscope slides. The cells were viewed with a Zeiss microscope, equipped with epifluorescent illumination using the appropriate filters for fluorescein fluorescence. Pictures were taken with Planopo 40x and $63 x$ oil immersion objectives on Tri-X film using an ASA-setting of 800 .

Labeling of lens cell proteins and preparation of cell lysates

Confluent monolayers of bovine lens epithelial cells, growing in plastic tissue culture flasks of $200 \mathrm{~cm}^{2}$ were incubated for $16-20 \mathrm{hrs}$ with $\mathrm{L}-\left[{ }^{35} \mathrm{~S}\right]$-methionine $(5 \mu \mathrm{Ci} / \mathrm{ml}$ medium) in lens tissue culture medium lacking methionine. After incubation the medium was decanted and the cells rinsed twice with tyrode buffer. Then the cells were harvested from the surface with a rubber policeman, centrifuged at low speed and washed with tyrode buffer. The cells were lysed with a Dounce potter in a cytoskeleton stabelizing buffer (50 mM Tris/HCl $\mathrm{pH} 7.4 ; 25 \mathrm{mM} \mathrm{KCl} ; 5 \mathrm{mM} \mathrm{MgAc} 2$, TKM buffer).

To obtain both TKM buffer soluble and insoluble proteins (the membrane cytoskeleton complex) the lysates were centrifuged at 10,000xg and the resulting pellet washed three times in TKM buffer. For analysis of the proteins by gel electrophoresis either freeze-dried or TCA-precipitated protein fractions were used. 
Gel electrophoretic analysis

Protein analysis was performed by two-dimensional gel electrophoresis using both isoelectric focusing and non-equilibrium-pH-gradient isoelectric focusing in the first dimension, according to the method

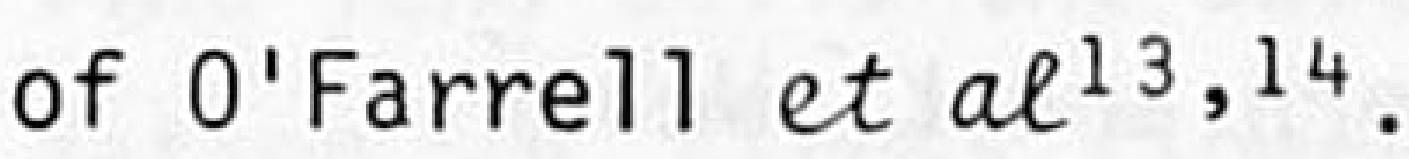

Radioactive spots were visualized by scintillation autoradiography ${ }^{5}$, in combination with the drying procedure described by Berns and Bloemendal ${ }^{16}$.

Highly purified bovine brain $\beta$ - and $\gamma$-actin and rat brain tubulin were used as protein markers. (Kindly provided by $\mathrm{Dr}$ I. Vandekerckhove and Dr I. Sandoval, respectively, Max Planck Institute for Biophysical Chemistry, Göttingen, Germany.)

Quantitative estimation of globular and filamentous actin

Monomeric and filamentous actin were quantitatively assayed in lens cell extracts using inhibition of deoxyribonuclease I essentially as described by Blikstadt et al ${ }^{17}$.

Drug incubation of the cells

Cells grown on coverslips in Leighton tubes were incubated with cytochalasin B or colchicine for 3-24 hrs. To reverse the effect of the former drug the medium was refreshed (no cytochalasin B present) and the cells studied during several time intervals. Phase-contrast microscopy was performed with a Leitz Diavert.

Incubation of the cells with extracts of the retina (15 mg protein/ $\mathrm{ml}$ extract; $0.5-1 \mathrm{mg}$ protein/ml culture medium) was essentially as described ${ }^{4}$.

\section{RESULTS}

Reorganization of the microfilament bundle distribution upon elongation

Bovine epithelial lens cells brought in culture retain their cuboidal shape at least during the first 15 passages. Occasionally, some elongated cells are observed. After about 20 transfers the cells start to change their appearance spontaneously resulting in elongated cells. Elongation of cultured bovine lens cells can also be induced by dexa- 
methasone ${ }^{3}$ or by an extract of the bovine retina ${ }^{4}$.

In the phase-contrastmicroscope these elongated cells exhibit pronounced intracellular filamentous organizations running parallel to the direction of elongation and crossing the whole length of the cell. These filaments can be visualized by the indirect immunofluorescence technique by using highly specific antibodies directed against actin (see Fig 1). In this way these filaments are identified as microfilament bundles.
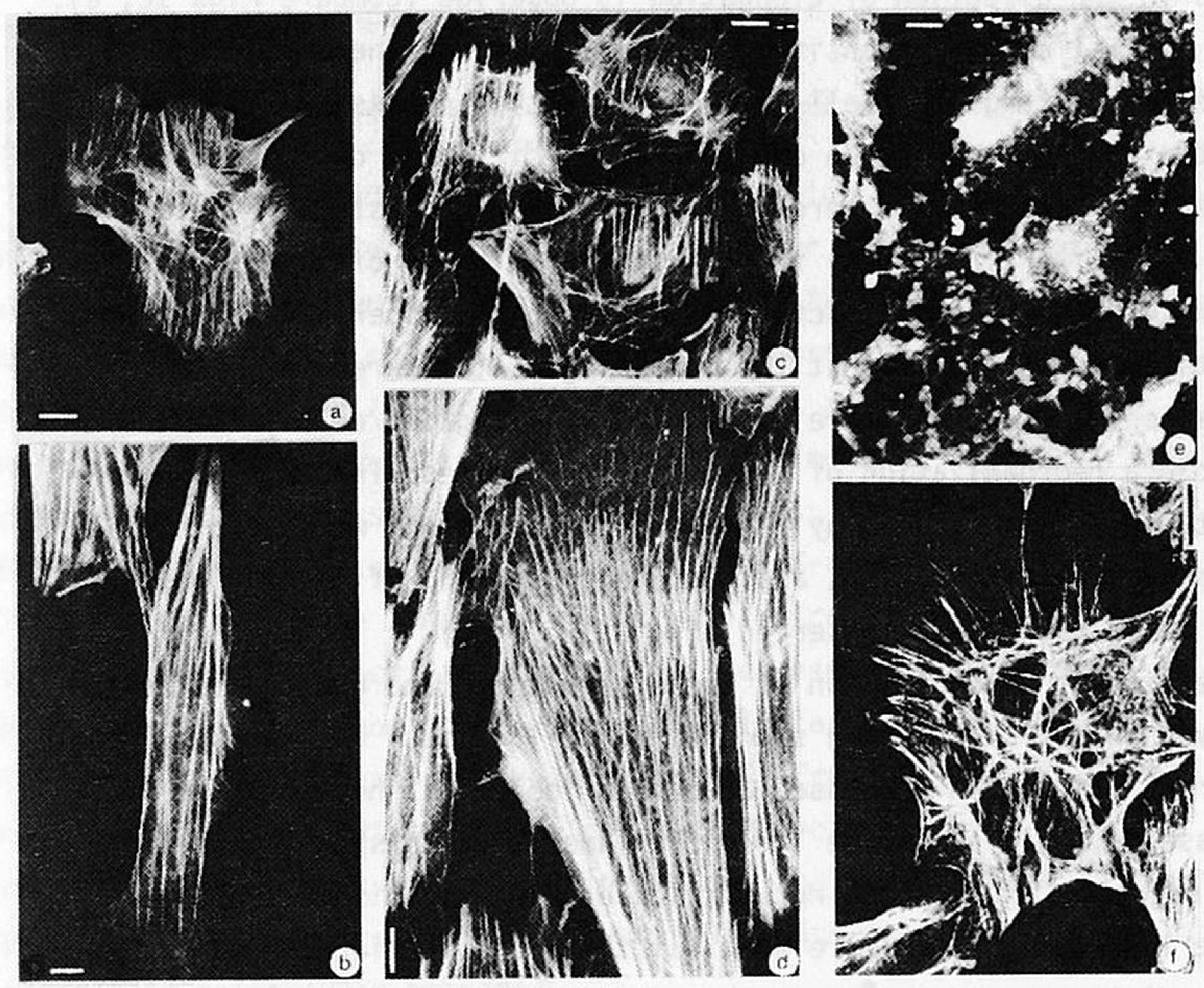

Fig 1 Immunofluorescence micrographs of cultured bovine lens cells incubated with antibodies to actin.

( $a$ and c) Young polygonal cells; c) confluent monolayer

(b) A cell elongated spontaneously upon aging

(d) Cells elongated after addition of a retinal extract to the growth medium

(e) Diffuse and spotty actin fluorescence after treatment of the cells with cytochalasin B

(f) 'Geodesic domes' in cells of intermediate passage number (11th passage). Bars indicate $10 \mu \mathrm{m}$. 
When young, cuboidal cells are incubated with the specific antibodies directed against actin a rather random distribution of the microfilaments (microfilament bundles) is observed (Fig la). In elongated cells, in cultures of higher passage number (30-40 transfers) strong arrays of parallel stress fibers occur, often running across the whole length of the cell in the direction of elongation (Fig 1b). Also young cells that have been incubated with retinal extracts elongate within 48 hours. Again a drastic reorganization of stress fibers in the direction of elongation is observed (compare Figs 1c, d).

An optimal cellular density is needed to induce the morphological change, suggesting that cell-to-cell contact is necessary. To show that the immunofluorescence observed is specifically due to actincontaining fibers, cells were treated with cytochalasin B. Fig le shows that after incubating the cells with this microfilament disrupting drug, only spotty actin fluoresecence is observed. From these results it is concluded that the morphological differentiation of bovine lens cells in culture (resulting in elongated cells) is accompanied by a reorganization of microfilament bundles. In cells of intermediate age (as reflected by the number of passages) which did not yet show pronounced elongation, a structure consisting of regular polygonal actin networks is observed (Fig 1f).

The highest concentration of these structures and greatest size is observed in cells that were subcultured 10-15 times. Further subculturing results in decreased amounts of polygonal networks and a decrease in their size (see Table I). These results show that a transient organization of actin networks occurs in established flattened bovine lens cells in culture and that this organization represents an intermediate structure between the random distribution of actin fibers in polygonal cells and strongly organized parallel arrays of stress fibers in elongated cells.

Antibodies directed against tubulin and vimentin were also tested on both cuboidal and elongated lens cells in culture (results not shown). The results showed that real reorganization occurred neither for microtubules nor for intermediate-sized filaments during lens cell elongation in vitro. At most there is some adjustment of the latter structures to the changing cell shape. 
Table I DISTRIBUTION OF 'GEODESIC DOMES' IN ELONGATING CULTURED BOVINE LENS CELLS

\begin{tabular}{lll}
$\begin{array}{c}\text { Passage } \\
\text { number }\end{array}$ & $\begin{array}{c}\% \text { Cells containing } \\
\text { 'geodesic domes' }\end{array}$ & $\begin{array}{c}\text { Relative shape of } \\
\text { 'geodesic domes' }\end{array}$ \\
\hline 1 & $16 \%$ & medium \\
10 & $23 \%$ & large \\
34 & $5 \%$ & small \\
& $5 \%$ & very small
\end{tabular}

Microfilament assembly during in vitro lens cell elongation as quantitated by the DNase I inhibition assay

As can be concluded from the foregoing section microfilaments do play an important role in the elongation and/or maintenance of the cell shape of calf lens cells in monolayer culture. In order to get an impression of the molecular basis of this process the ratio between globular-actin (G-actin) and filamentous actin (F-actin) was estimated in both young, cuboidal cells and elongated cells in culture. The method used for these estimations, first described by Blikstad et al ${ }^{17}$, makes use of the fact that G-actin specifically inhibits DNase I. The amount of F-actin is calculated by subtracting the amount of G-actin (estimated in the absence of guanidine hydrochloride) from the total amount of cellular actin (estimated in the presence of guanidine hydrochloride). From the results summarized in Table II it becomes clear that there is a shift from Gactin to F-actin upon lens cell elongation. The total amount of actin per cell increases from $1.9 \%$ in young cells (6th passage) to $4.1 \%$ in elongating cells (22nd passage).

Table II DISTRIBUTION OF F-AND G-ACTIN IN ELONGATING CULTURED BOVINE LENS CELLS

\begin{tabular}{rrc}
\hline Passage No & G-actin & F-actin \\
\hline 6 & $61 \%$ & $39 \%$ \\
22 & $48 \%$ & $52 \%$ \\
37 & $26 \%$ & $74 \%$ \\
\hline
\end{tabular}




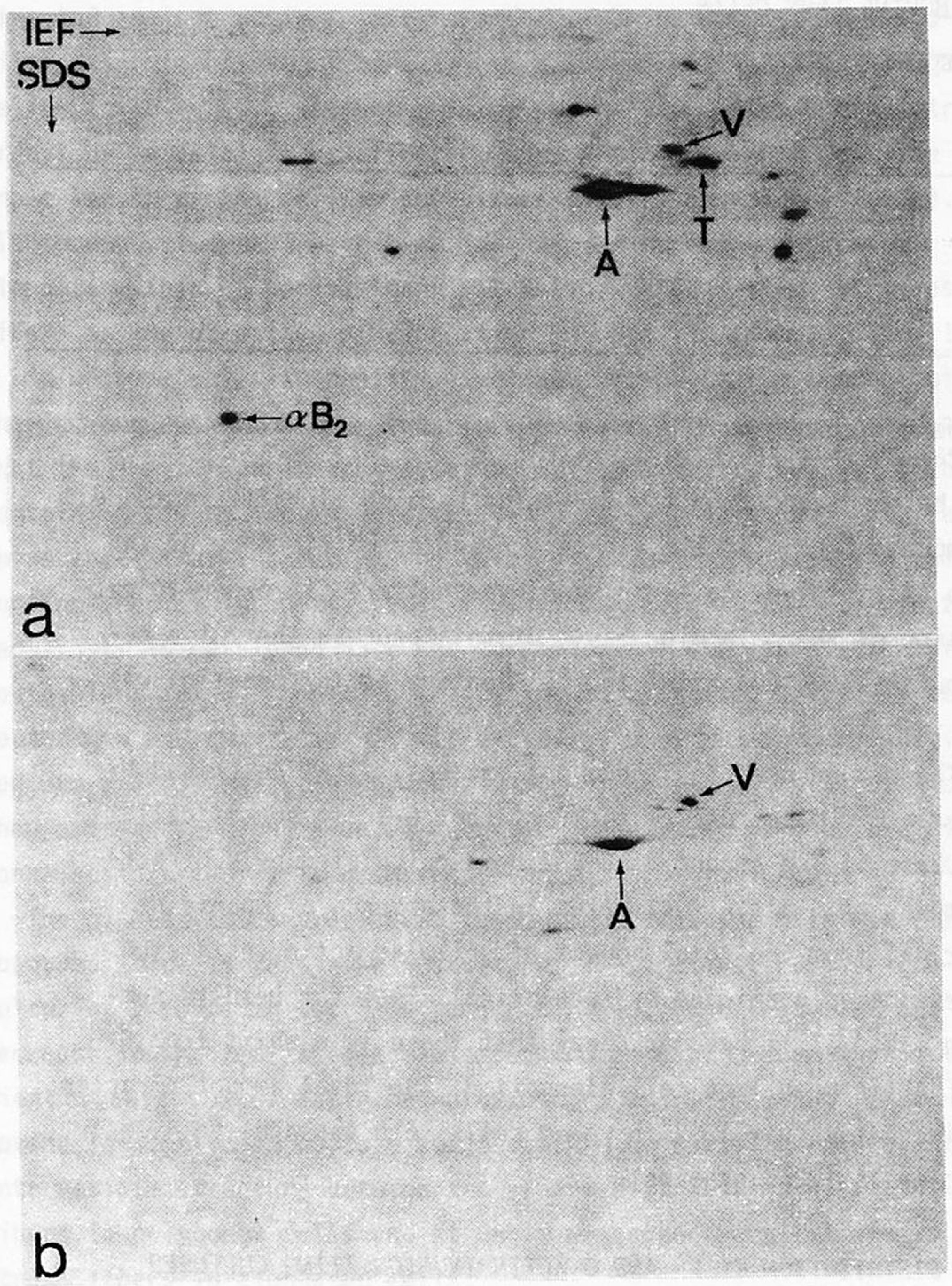

Fig 2 Autoradiographs of 2D-gel electrophoretic patterns of newly synthesized polypeptides in (a) primary bovine lens cell culture and (b) in older elongated cells. ( $A=$ actin; $T=$ tubulin and $\mathrm{V}=\mathrm{vimentin. \text {) }}$ 
Decreased tubulin and crystallin synthesis in elongating bovine lens cells in culture

When cuboidal and elongated bovine lens cells in monolayer cultures are compared with respect to their protein biosynthetic activity (Fig 2) it is obvious that the synthesis of both of crystallin and tubulin is not detectable in the elongated cells. This phenomenon is observed already after 2-3 passages, long before the cells start to elongate. However, immunofluorescence shows the presence of microtubuli also in elongated cells, which means that a low level of tubulin synthesis must occur.

From these results we conclude that neither tubulin nor crystallin synthesis are a prerequisite for bovine lens cell elongation in vitro. This does not exclude a role of microtubuli in this process, since the assembly of these structures may be independent of tubulin synthesis but may merely represent an equilibrium between a soluble and a cytoskeletal form of tubulin.

\section{Studies using cytochalasin $B$ and colchicine}

The effect of cytochalasin B on calf lens epithelial cells in culture is shown in Fig. 3. In this picture three stages of in vitro elongating lens cells are depicted which all exhibit the typical arborized shape when incubated with the drug $10 \mu \mathrm{g} / \mathrm{ml}$ growth medium). However, the effect of cytochalasin B seems to be more drastic in older cultures with elongated cells than in the younger ones containing the cuboidal-shaped cells. Surprisingly the differential effect of cytochalasin B on calf lens cells becomes more pronounced when the drug is withdrawn after several hours of incubation. Once, the young cells that where formerly of polygonal shape regain their original form within 3 hours, while the older originally elongated cells do not restore their shape (even after maintenance for $24 \mathrm{hrs}$ in normal serum). Cells of intermediate age show only a partial recovery after 24 hrs.

These results provide evidence for an involvement of microfilaments in the structure of lens cells in culture and suggest an important role of actin-containing stress fibers in elongated cells in vitro. Furthermore there seems to be a differential irreversible 


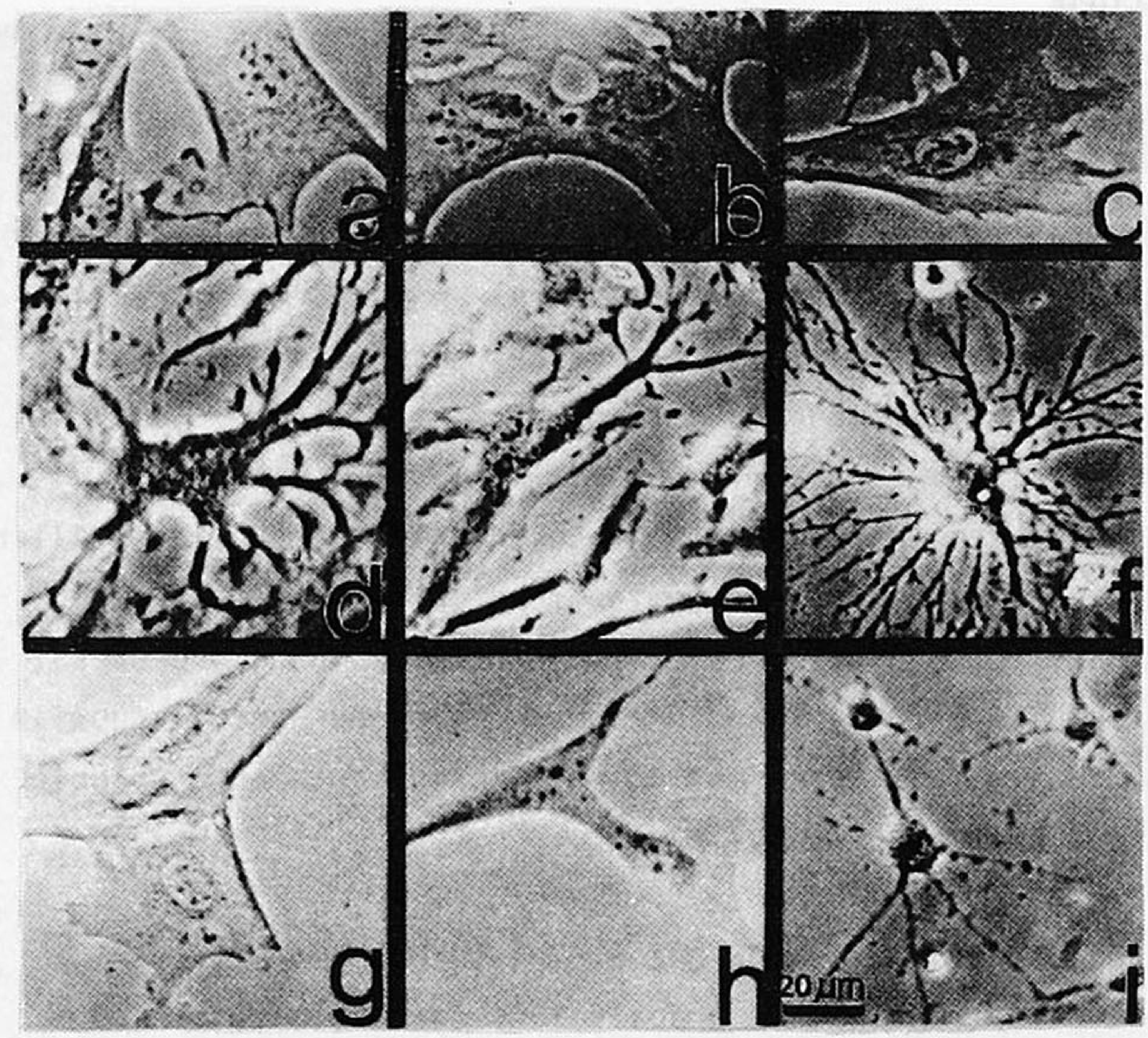

Fig 3 Treatment of cultured bovine epithelial lens cells with cytochalasin B (CB)

$(a, b, c)$ Untreated cells that have been subcultured 2, 10 and 30 times, respectively

(d, e, f) The same cells treated with $C B$

$(g, h, i)$ Same cells $24 \mathrm{~h}$ after fresh medium, depleted of CB has been added.

effect of cytochalasin B on the microfilaments in senescent, elongated cells, which structures may occur less frequently in young cells or, alternatively may not be functional in the maintenance of their cell shape.

The effects of cytochalasin B and colchicine on the process of bovine lens cell elongation in vitro under the direction of a retinal extract were also examined. Arruti and Courtois ${ }^{4}$ showed an inhibitory effect of colchicine (in concentrations of $6 \times 10^{-5}$ to $\left.6 \times 10^{-9} \mathrm{M}\right)$ on the elongation of adult bovine epithelial lens cells.

Van Venrooij et al demonstrated that cytochalasin B $(5 \mu \mathrm{g} / \mathrm{ml}$ medium) did not prevent elongation of calf lens cells under the 
direction of dexamethasone. Therefore, one would expect a role of microtubules in the process of lens cell elongation in vitro as previously proposed for chick lens ${ }^{6}$. Careful examination, however, shows that concentrations of both cytochalasin B and colchicine that change the shape of normal nonelongating cells, also inhibit elongation (Table III).

Table III THE EFFECT OF COLCHICINE AND CYTOCHALASIN B ONTHE ELONGATION OF BOVINE LENS CELLS IN CULTURE UNDER THE DIRECTION OF RETINAL EXTRACTS

\begin{tabular}{cccc}
\hline $\begin{array}{c}\text { R.E. } \\
(\mu 1 / 5 \mathrm{ml} \text { medium })\end{array}$ & Colchicine (mM) & Elongation & $\begin{array}{c}\text { Cell shape } \\
\text { changes }\end{array}$ \\
\hline- & - & - & - \\
- & $6.25 \times 10^{-9}$ & - & - \\
- & $6.25 \times 10^{-7}$ & - & - \\
200 & - & +++ & elongation \\
200 & $6.25 \times 10^{-9}$ & ++ & elongation \\
200 & $6.25 \times 10^{-7}$ & ++ & elongation \\
200 & $6.25 \times 10^{-6}$ & - & arborization \\
200 & $6.25 \times 10^{-4}$ & - & arborization
\end{tabular}

\begin{tabular}{cccc}
\hline \multicolumn{5}{c}{$\begin{array}{c}\text { Cytochalasin B } \\
(\mathrm{mM})\end{array}$} & - & \\
\hline- & - & - & - \\
- & $2 \times 10^{-9}$ & - & - \\
- & $2 \times 10^{-6}$ & ++ & elongation \\
300 & - & ++ & elongation \\
300 & $2 \times 10^{-7}$ & ++ & elongation \\
300 & $2 \times 10^{-6}$ & - & arborization \\
300 & $2 \times 10^{-5}$ & - & arborization \\
300 & $2 \times 10^{-4}$ & - & arborization \\
300 & $2 \times 10^{-3}$ & & \\
\hline
\end{tabular}

On the other hand, as soon as the drug concentrations are so low that they do not affect the cell shape, they also do not prevent elongation. 
A role of $B$-actin and myosin in in vitro lens cell elongation

Closer examination of cytoskeletal preparations from young cuboidal calf lens epithelial cells and elongated cells revealed some interesting aspects concerning the molecular processes involved in microfilament bundle assembly during elongation in vitro. Fig 4 shows a one-dimensional gel containing samples of lens cell cytoskeletons next to molecular weight markers for the main cytoskeletal constituents actin, vimentin and myosin.

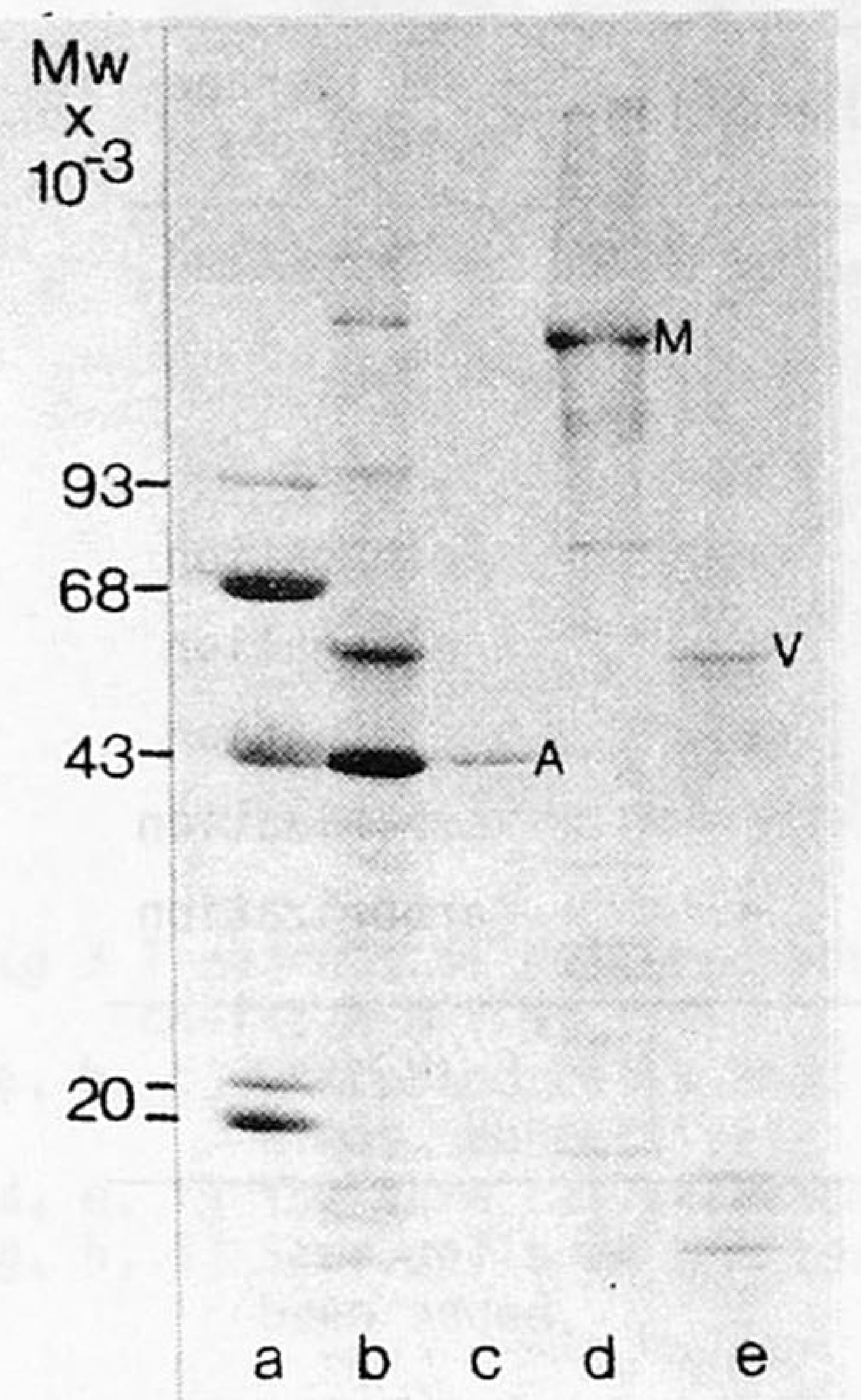

Fig 4 SDS-gel electrophoretic analysis of polypeptides that make up the cytoskeleton-membrane complex in cultured bovine epithelial lens cells.

a) Marker proteins ( $\alpha$-crystallin, 20,000 D; ovalbumin, 43,000 D; bovine serum albumin, 68,000 D and phosphorylase $A, 93,000 \mathrm{D})$

b) A cytoskeletal preparation from cultured lens cells

c) Actin from bovine brain (A)

d) Rabbit muscle myosin (M)

e) Vimentin (V) in a Triton/KCl-cytoskeleton preparation from bovine lens cells in culture.

It can be seen that in the high mol weight region a major band of the lens cells comigrates with rabbit muscle myosin. Since it has been described that myosin cannot be detected by the conventional 2D-gel electrophoretic technique 13,18 we chose the modified procedure as described by $0^{\prime}$ Farrel ${ }^{14}$. Newly synthesized proteins incorporated into the cytoskeletal fractions and isolated as described in the Method section, were analyzed in this way and autoradiographed. Cytoskeletal protein patterns from cells of increasing passage number are shown in Fig 5 . 


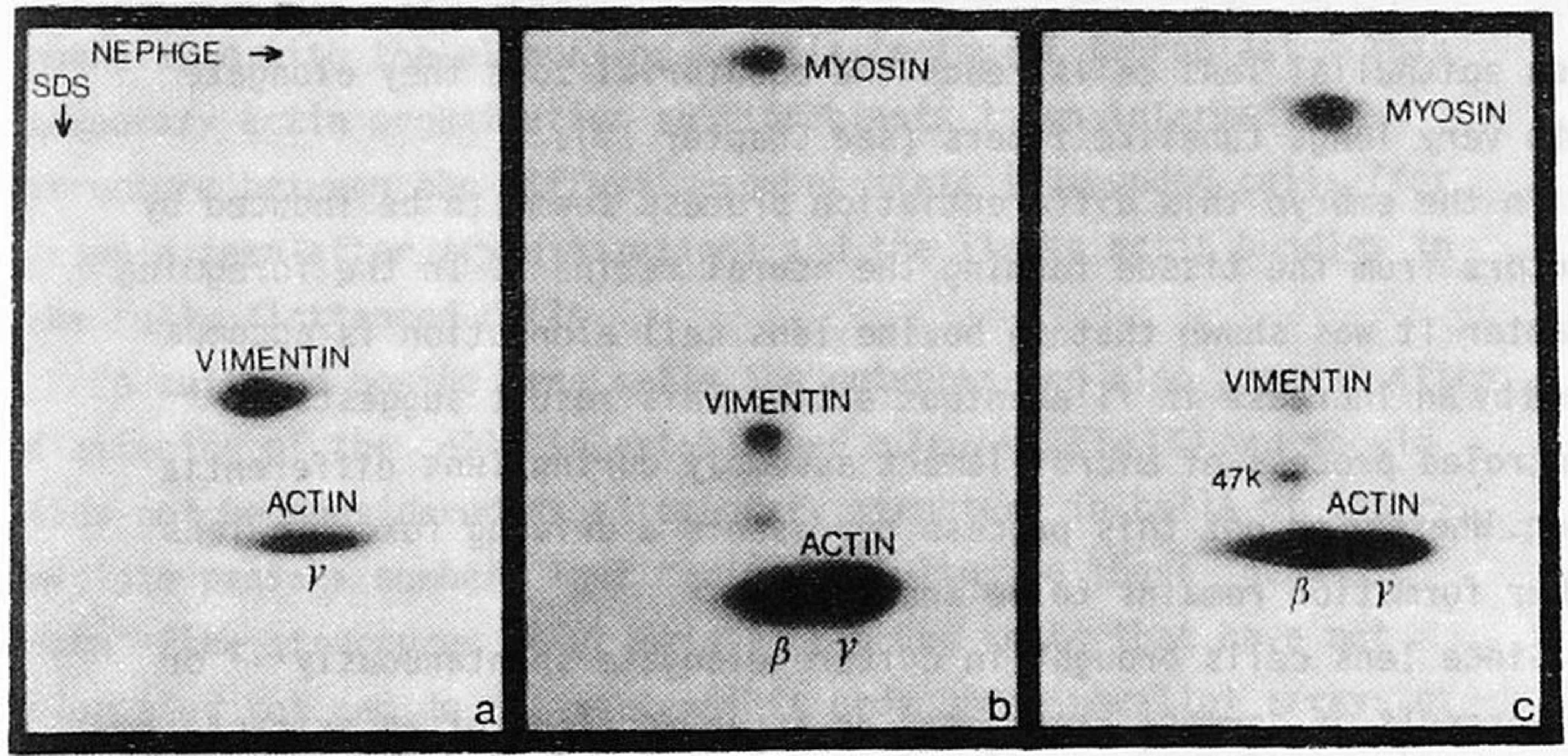

Fig 5 Incorporation of $\beta$-actin and myosin into stress-fibers of elongating lens cells.

Autoradiographs of 2D-gel electrophoretic patterns of the cytoskeletons derived from bovine epithelial lens cells of different age; (a) from primary cells still growing on the capsule; (b) cells after 17 passages; (c) cells after 35 passages.

A clear change in the intensity of vimentin relative to actin can be observed going from polygonal to elongated cells. This observation is paralleled by the finding in vivo where a similar change was seen in electron micrographs of epithelial and fiber cells ${ }^{11}$. Furthermore, the incorporation of myosin synthesized de novo gradually increases. At the same time the incorporated $\beta$-actin which is virtually absent in the cytoskeletal preparation from young cells becomes more pronounced. In the total cell extracts of primary and elongated cells both $\beta$ - and $\gamma$-actin are present, however. In older preparations a hitherto unidentified $47 \mathrm{kD}$ protein is found. Its intensity increases upon aging or elongation of the cells. 
When epithelial lens cells reach the equatorial zone they elongate into very long, tubelike fibers (see Chapter IV).

In the embryo this differentiation process seems to be induced by factors from the tissue forming the neural retinal9. In the foregoing chapter it was shown that in bovine lens cell elongation is accompaniedby an increase in filamentous actin. This result suggests a controled process of microfilament assembly during lens differentiation. Whether or not this process represents a driving force in lens fiber formation remains to be answered.

Since lens cells brought in culture elongate spontaneously ${ }^{1,2}$ or as a result of hormone treatment ${ }^{3}$ or after addition of an extract from the retina ${ }^{4}$ we wondered whether this phenomenon had some aspects in common with the in vivo differentiation process. Some of the typical differentiation markers, the crystallins and an intrinsic membrane protein, MP26, are undetectable in the elongated cells in culture. However, because of the complexity of tissue differentiation we have to keep in mind that next to these specific proteins, the biosynthesis of other cell constituents may be a prerequisite for differentiation.

The results presented here are in favor of the idea that the biochemistry of this function of microfilaments in lens cell elongation may be studied in bovine lens cell cultures. We are fully aware of the fact that cells in monolayers, growing under artificial conditions have to adapt to their new situation, in which environmental and feedback mechanisms of regulation are completely different. However, especially those constituents involved in cellular motility processes and that maintain cell shape are retained in vitro.

Especially actin seems to play a role in the elongation of lens cells in culture. An increase in the assembly of microfilaments, may be a factor that directs the onset of morphological changes. Furthermore a structure consisting of regular polygonal networks is observed especially in cells that do not yet show pronounced elongation. These structures have been described earlier by Lazarides ${ }^{7}$ in fibroblasts and designated 'geodesic domes' which encompass the entire area above and around the nucleus and had a-actinin localized at the vertices 
of the network. The vertices are thought to act as organization centers for actin-filament bundles resulting in or correlated with the elongation and flattening of fibroblasts. This temporary actin organization in fibroblasts is an intermediate structure between the diffuse meshwork state in rounded cells (for example seen after trypsinization) and the linear actin bundles in the fully flattenend cells.

In cultured bovine lens cells the networks are also present after flattening of the cells in established cultures (Fig 1f) and should thus not be considered as a temporary structure in cells of intermediate passage number. Thus during subculturing these 'geodesic dome'-like structures occur mainly in young cells that have not elongated yet and do not yet exhibit pronounced parallel arrays of stress fibers. Microtubules do not seem to play an important role in the elongation process since tubulin synthesis diminishes.

Arutti and Courtois ${ }^{4}$ reported that protein biosynthesis seems to be necessary for the elongation of cultured bovine lens cells under the direction of a retinal extract. Furthermore, these authors claimed that protein biosynthesis is a requirement for the maintenance of the elongated shape. This was concluded from the reversal to the polygonal shape of previously elongated cells if treated with cycloheximide. This latter result is surprising, since Piatigorsky 6 showed that chick lens epithelial explants are independent of protein biosynthesis for their elongation induced by insulin or under certain growth medium conditions. If the observation made by Arutti and Courtois ${ }^{4}$ that elongation is dependent upon protein synthesis holds also true for the calf lens system, one has to conclude that rather microfilaments than microtubules play a major role in lenticular cell elongation in vitro. An assembly of microtubules, independent of tubulin biosynthesis can, however, not be excluded.

Mousa and Trevithick ${ }^{10}$ have reported a differential effect of cytochalasin $B$ and $D$ on cuboidal and elongated rat lens cells in culture. Young cells, which have not yet elongated are less sensitive to treatment with these drugs than are the elongated ones, which readily arborize. The cytochalasins inhibit elongation in cultures from rat lens epithelial cells $s^{10}$, calf lens cultures ${ }^{4}$ and chick lens epithelium 
explants ${ }^{8}$. Similar results are obtained in our experiments. However, also colchicine was found to inhibit elongation under the direction of a retinal extract and resulted in an arborized cell shape. This shows that both microtubules and microfilaments may be involved in elongation and/or maintenance of cell shape. Therefore, taking into consideration all the available data we want to propose in agreement with Dustin 20 a more static role for microtubules and a rather dynamic role for microfilaments in lens cell elongation. 


\section{REFERENCES}

1. Venrooy van, W.J., Groeneveld, A.A., Bloemendal, H. and Benedetti, E.L., Exp. Eye Res. 18 (1974) 517.

2. Mungyer, G. and Jap, P.H.K., Interdiscipl. Topics Gerontol. 12 (1978) 13.

3. Venrooy van, W.J., Groeneveld, A.A., Bloemendal, H. and Benedetti, E.L., Exp. Eye Res. 18 (1974) 527.

4. Arutti, C. and Courtois, Y., Exp. Cell Res. 117 (1978) 283.

5. Piatigorsky, J., Dev. Biol. 30 (1973) 214.

6. Piatigorsky, J., Ann. N.Y. Acad. Sci. 253 (1975) 333.

7. Lazarides, E., J. Cell Biol. 68 (1976) 202.

8. Piatigorsky, J., Webster, H. de F. and Wollberg, M., J. Cell Biol. 55 (1972) 82.

9. Beebe, D.C., Feagans, D.E., Blanchette-Mackie, E.J. and Nau, M.E., Science 206 (1979) 836.

10. Mousa, G.Y. and Trevithick, J.R., Dev. Biol. 60 (1977) 14.

11. Ramaekers, F.C.S., Osborn, M., Schmid, E., Weber, K., Bloemendal, H. and Franke, W.W., Exp. Cell Res. 127 (1980) 309.

12. Webster, R.E., Osborn, M. and Weber, K., Exp. Cell Res. 117 (1978) 47.

13. O'Farrell, P.H., J. Biol. Chem. 250 (1975) 4007.

14. O'Farrell, P.Z., Goodman, H.M. and O'Farrell, P.H., Cell 12 (1977) 1133.

15. Bonner, W.J. and Laskey, R.A., Eur. J. Biochem. 46 (1974) 83.

16. Berns, A.J.M. and Bloemendal, H. In: Methods in Enzymology Vol 30 (Moldave, K. and Grossman, C., Eds.) pp 675. Academic Press, New York (1974).

17. Blikstad, I., Markey, F., Carlsson, L., Persson, T. and Lindberg, U., Cell 15 (1978) 935.

18. Izant, J.G. and Lazarides, E., Proc. Nat1. Acad. Sci. USA 74 (1974) 1450.

19. Coulombre, A.J. In: Organogenesis (De Haan, R.L. and Ursprung, H., Eds.) Holt Rinchart and Winston, New York (1965) 219.

20. Dustin, P., Microtubules. Springer Verlag, Berlin (1978). 


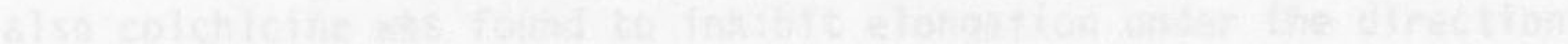

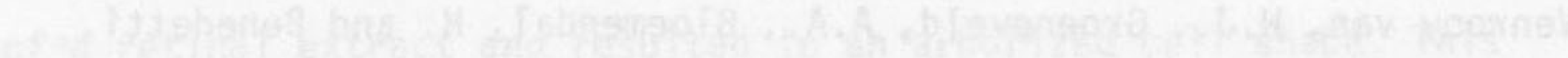

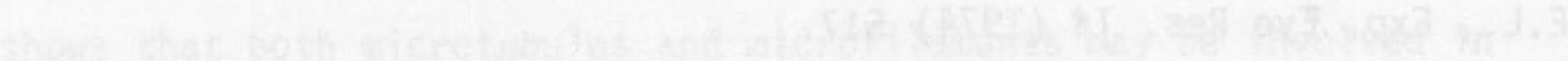

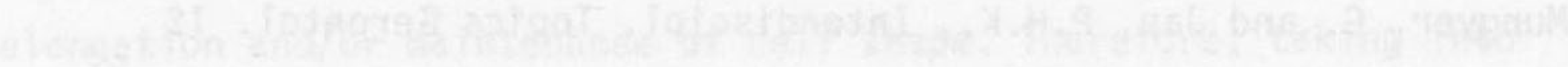

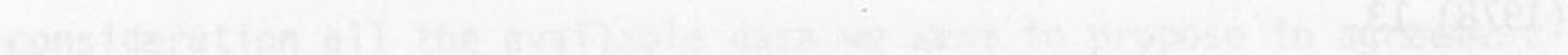

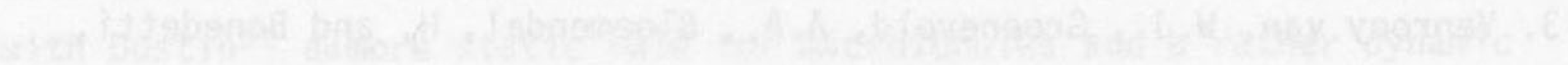

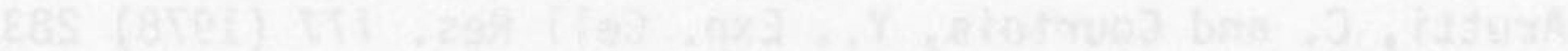
Fis:

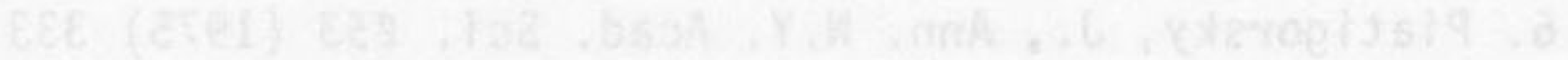

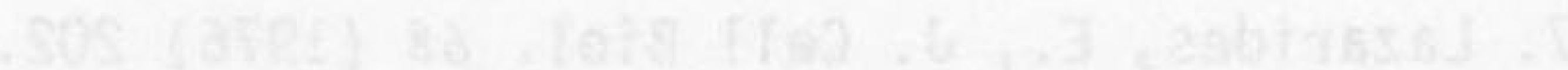

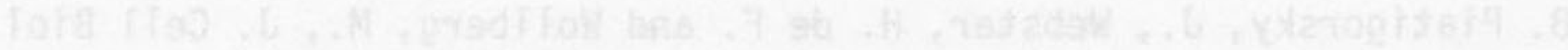

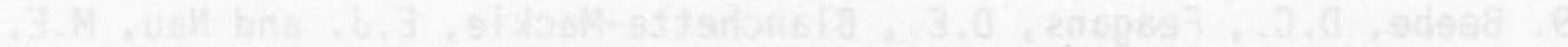

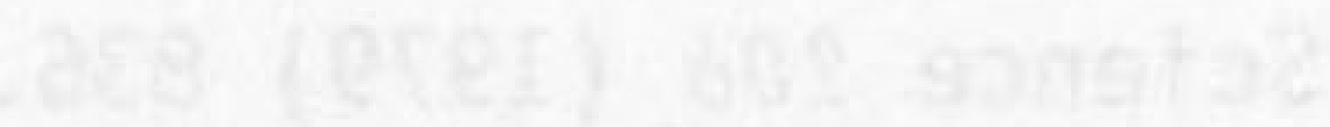

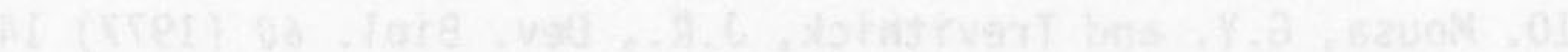

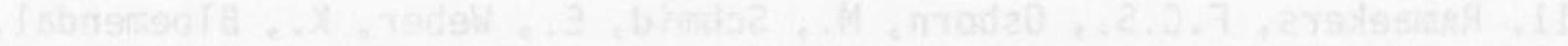

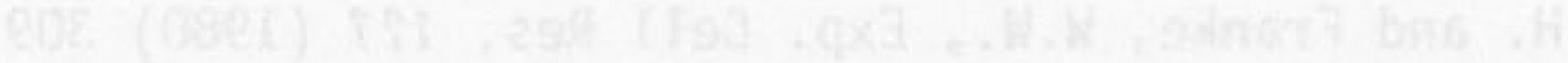

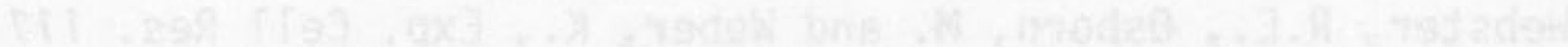

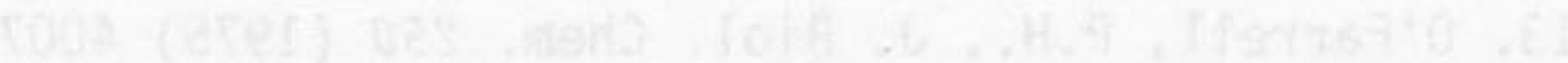

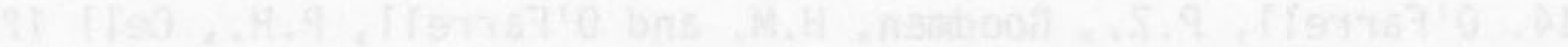

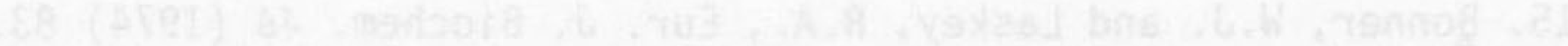

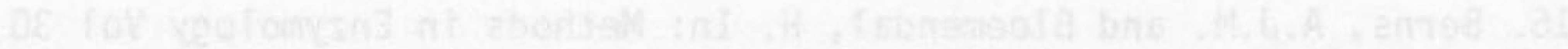

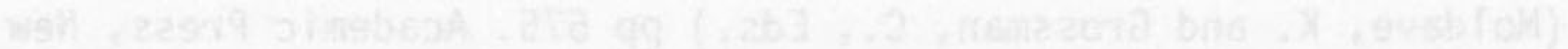

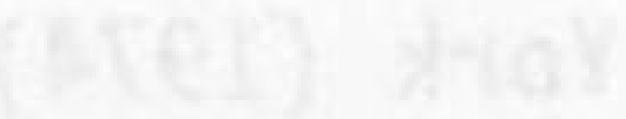

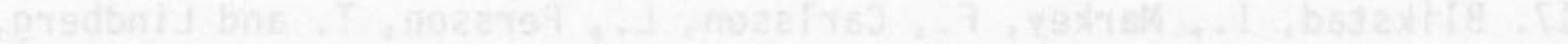

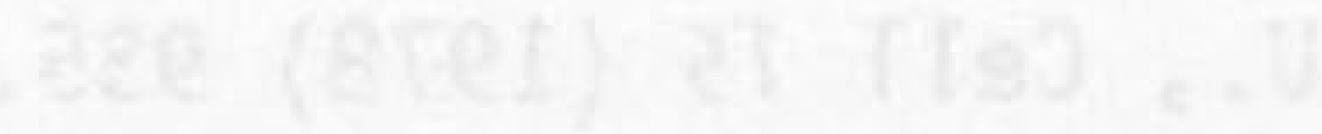

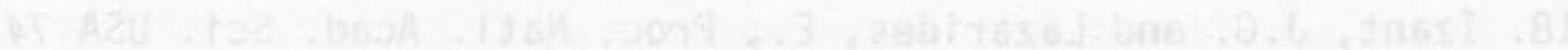

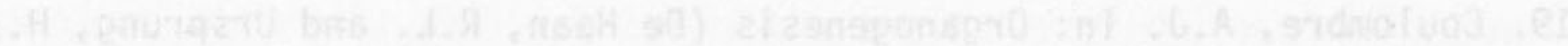

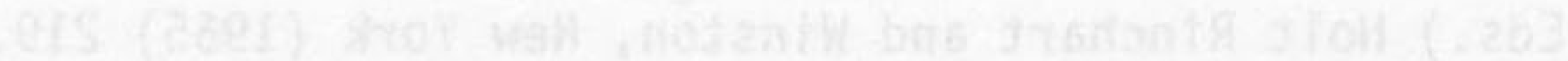

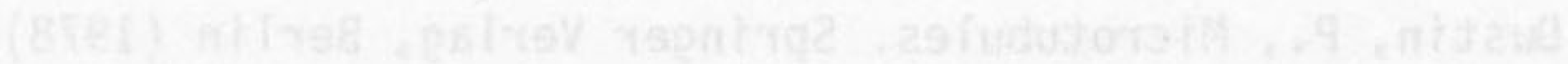


CHAPTER VI

POLYRIBOSOMES ASSOCIATED WITH MICROFILAMENTS IN CULTURED LENS CELLS 
CHAPTER VI

POLYRIBOSOMES ASSOCIATED WITH MICROFILAMENTS IN CULTURED LENS CELLS

SUMMARY

Epithelial hamster lens cells, transformed by SV40 can be grown in suspension culture. Triton $X-100$ extraction of these cells releases about $36 \%$ of the total amount of (poly)ribosomes, designated as free- and loosely membrane-bound polyribosomes. The Triton ghosts retain about $60 \%$ of the total polysomal population that can be released by a double detergent treatment (deoxycholate/NP40). Electron microscopic examination of the ghosts reveals microfilament-associated ribosome clusters next to a fraction of polysomes still attached to membranes. Preincubation of the cells with Cytochalasin D prior to polyribosome isolation unables to discriminate between the two latter polysome fractions. The experiments indicate that about $25 \%$ of the polyribosomes are attached to microfilaments, while the remaining $35 \%$ appear to be tightly bound to the membranes of the endoplasmic reticulum.

When the different polyribosome classes were translated in a reticulocyte lysate, no significant differences could be observed in the patterns of the newly synthesized polypeptides. In all cases actin was one of the major products synthesized de novo.

\section{INTRODUCTION}

Several reports in the literature have provided evidence for a link between polyribosomes and the cytoskeleton ${ }^{1-5}$. We have recently reported the interaction of a specialized polyribosome fraction with actin filaments in lens fibers ${ }^{6}, 7$ (see Chapter VII). These polyribosomes, that can be released from the plasma membrane cytoskeleton complex by DNase I treatment, synthesize the main intrinsic bovine lens plasma membrane protein MP26 ${ }^{8}$.

In search for a cell system derived from lens tissue that would enable us to manipulate conditions of growth and allow the study of drug effects 
on polyribosome-microfilament interactions we started to use SV40 transformed epithelial hamster lens cells. These cells grow continuously in suspension culture ${ }^{9}$ and form tumors when injected into nude mice ${ }^{10}$. Although crystallin synthesis in these cells has stopped (or decreased to a nondetectable level), several criteria indicate that these cells are indeed lens cells (compare 10-12).

Electron microscopic results ${ }^{9}$ already indicated that in these cells three populations of polyribosomes are present, namely

a) free polyribosomes

b) cytoskeleton-bound polyribosomes and

c) membrane-bound polyribosomes.

In the underlying study we present more detailed data on the nature of these fractions and their biochemical behavior.

\section{MATERIALS ANO METHOOS}

Establishment of the hamster lens epithelial cell line

Lenses from 8 weeks-old Syrian gold hamsters were rinsed with $0.35 \%$ trypsin in $\mathrm{Ca}^{2+}$ - and $\mathrm{Mg}^{2+}$-free Tyrode solution in order to remove adhering material. The tissue was divided over 2 Falcon flasks (bottom: $25 \mathrm{~cm}^{2}$ ), minced with scissors, partially dried for 15 min in order to promote adhesion and incubated at $37^{\circ} \mathrm{C}$ in $5 \mathrm{ml}$ of a medium derived from the following stock solution: $1.5 \mathrm{~g}$ lactalbumin hydrolysate dissolved in $800 \mathrm{ml}$ double-distilled water supplemented with $30 \mathrm{ml}$ HANKS B solution, both twenty times concentrated (Medium A). $3.24 \mathrm{~g}$ Tel99 powder medium, dissolved in $40 \mathrm{ml}$ double-distilled water and filtered through a $0.2 \mu$ millipore filter (Medium B), is added to Medium A. Shortly before use, calf serum, $100 \mu \mathrm{g} / \mathrm{ml}$ penicillin, $100 \mu \mathrm{g} / \mathrm{ml}$ streptomycin and $20 \mathrm{ml}$. of a $0.2 \mathrm{M}$ glutamine solution is added. Firstly a monolayer culture is obtained which is maintained as reported previously for cultured calf lens epithelium ${ }^{13}$. Transformation was achieved by incubation with $5 \mathrm{ml}$ of a JL SV40 suspension (kindly provided by $\operatorname{Dr} A$. Berns from our laboratory) in the presence of $4 \mu \mathrm{g} / \mathrm{ml}$ polybrene. The titer of the virus was $10^{7} / \mathrm{ml}$, measured in an XC-cell plaque assay.

The transformed cell line was brought into suspension in Eagle's 
minimal essential suspension medium, supplemented with $20 \%$ fetal calf

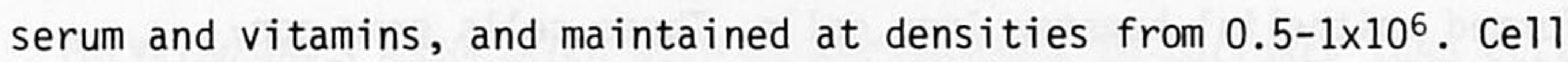
division occurred every 15-20 hours. For storage, cells were frozen in a mixture of 10\% dimethylsulfoxide, $70 \%$ HANKS-buffer and $20 \%$ fetal calf serum and stored in liquid nitrogen. When stock-cells were used ampulles were defrozen rapidly and after removal of DMSO the cells were resuspended in normal growth medium.

\section{Electron microscopy}

Cells from the suspension culture were gently centrifuged at $800 \times \mathrm{xg}$ and washed with the culture medium. 3.5\% Glutaraldehyde in phosphate buffer was added to the cells resuspended in the culture medium. After 15 min of prefixation the cells were sedimented again and fixed for $1 \mathrm{~h}$ in the same buffered glutaraldehyde containing $1 \%$ of galloyl glucose. Thereafter the cells were repeatedly washed and postfixed in $1 \%$ osmium tetroxyde dissolved in the phosphate buffer. Then the cells were dehydrated and embedded in a mixture of epon-araldite. Thin sections were stained with uranyl acetate and lead citrate.

The same procedure was followed for observations of the Tritonghosts, with the modification that $1 \%$ tannic acid was added to the gluteraldehyde fixative.

Electron microscopic observations were made in a Philips EM 400.

Isolation and quantitation of polyribosome fractions

Cells grown to a concentration of $10^{6} \mathrm{cel} 1 \mathrm{~s} / \mathrm{ml}$ were sedimented and resuspended in fresh medium to a concentration of $5 \times 10^{6}$ cells $/ \mathrm{ml}$. After $2 \mathrm{~h}$ at $37^{\circ} \mathrm{C}$ the cells were washed twice at $0-4^{\circ} \mathrm{C}$ in HANKSbuffer by centrifugation in a Christ-centrifuge (10 min at $2000 \mathrm{rpm}$ ). In some experiments the cells were preincubated for 30 min with several concentrations of Cytochalasin D (Calbiochem). Furthermore, during these experiments emetine- $\mathrm{HCl}$ was added to the medium for 5 min in a concentration of $20 \mu \mathrm{g} / \mathrm{ml}$ growth medium before Cytochalasin $D$ was added.

In order to test the effect of emetine on polyribosome distribution, cells were incubated for 5 min prior to harvesting with increasing concentrations of the drug. Thereafter, RNase-free condi- 
tions were used for the polyribosome isolations. The cells were resuspended gently in TKM-buffer ( $50 \mathrm{mM}$ Tris- $\mathrm{HCl}, 25 \mathrm{mM} \mathrm{KCl}$ and $5 \mathrm{mM}$ $\mathrm{MgCl}_{2}, \mathrm{pH} \mathrm{7.4)} \mathrm{containing} 0.5 \%$ Triton $\mathrm{X}-100,0.3 \mathrm{M}$ sucrose and $1 \mathrm{mM}$ phenylmethylsulfonyl fluoride (PMSF) and incubated at $0-4^{0} \mathrm{C}$ for $5 \mathrm{~min}$. Occasionally, instead of this buffer the RSB-buffer as described by Lenk et $a \ell^{1,2}$ was used. After 10 min of centrifugation in a Christ centrifuge at $2000 \mathrm{rpm}$ the supernatant was layered on a $1.5-2 \mathrm{M}$ sucrose cushion in TKM-buffer and the polyribosomes isolated by centrifugation at $80,000 \times \mathrm{xg}$ for $16 \mathrm{~h}\left(4^{\circ} \mathrm{C}\right)$.

The pellet (containing the nucleus, the cytoskeleton and membranous structures) was washed once with TKM-buffer containing $1 \mathrm{mM}$ PMSF and thereafter incubated for 15 min in TKM-buffer containing $0.25 \%$ deoxycholate (DOC), 0.25\% Noninet NP40 and $1 \mathrm{mM}$ PMSF. The suspension was homogenized in a Dounce homogenizer using a B-pestle (15-20 strokes). After centrifugation (20 min, $5000 \mathrm{rpm}$ in a Christ, $4^{\circ} \mathrm{C}$ ) the supernatant was used for polyribosome isolation as described above. The TKM-wash was treated in the same way.

In some experiments the Triton-ghosts were incubated with DNase I $\left(20 \mathrm{\mu g} / \mathrm{ml}\right.$ TKM-buffer, $10 \mathrm{~min}$ at $\left.37^{\circ} \mathrm{C}\right)$. The $2000 \mathrm{rpm}$ pellet was extracted with deoxycholate as described while the supernatant was used for polyribosome isolation. The DNase I was made RNase-free by affinity chromatography on $5^{\prime}$-UTP agarose as described ${ }^{14}$. PMSF was added to the incubation whenever proteolytic activity had to be diminished.

Isolation of RNA by $\mathrm{Mg}^{++}$-precipitation was achieved as described by Palmiter 15 .

The polyribosome pellets were either diluted in bidestilled water or TKM-buffer and quantitated by measuring absorbtion at 260 and 280 $\mathrm{nm}$ in a Zeiss Spectrophotometer MQIII. Polyribosome profiles were obtained on $15-35 \%$ isokinetic sucrose gradients as described ${ }^{16}$. Approximately 6 OD-units of polyribosomes were layered onto the sucrose gradients.

\section{Cell-free translation and gel electrophores is}

Isolated polyribosome fractions from emetine free incubations were translated in an RNA-dependent reticulocyte cell-free system as described by Pelham and Jackson ${ }^{17}$. The newly synthesized products were 
analyzed by sodium dodecylsulphate polyacrylamide gel electrophoresis and the radioactive bands detected by fluorography ${ }^{8}$. Products were further characterized by two-dimensional gel electrophoresis as described by $0^{\prime}$ Farrel118.

\section{RESULTS}

\section{Cell culture}

The transformed hamster epithelial lens cells that were trypsinized from monolayers and transmitted into suspension medium showed strong growth already after $24 \mathrm{~h}$. In the preceding weeks the cells grew rapidly with a doubling time of about $15-20 \mathrm{~h}$. After about 6-8 weeks the doubling time of the cells gradually increases and the culture is lost after about 10 weeks. This phenomenon is rather surprising for transformed cells growing in culture which in principle have almost unlimited lifespans. The restricted number of cell divisions of this culture may reflect some inherent property of the epithelial lens cell, that in vivo after a certain number of cell divisions undergoes terminal differentiation paralled by a loss of mitotic activity. Similar results have also been observed for untransformed bovine lens cells in monolayer cultures ${ }^{19}$.

\section{Electron microscopy}

Electronmicroscopic observation of the cells growing in suspension show that these cellular elements are joined loosely together in a small group. The cell-to-cell interaction is ensured by intermingled digitations and microvilli. Moreover, small junctional regions are also visible mostly of the type of maculae adherens or intermediate junctions. Gap junctions are almost absent. Freeze fracturing studies still in progress will elucidate whether both gap and tight junctions participate in the cell-to-cell attachment and communication.

The general organization of the cytoplasm is characterized by a relatively poor developed rough endoplasmic reticulum (E.R.). This structure is represented by short regions of rather large cisternae filled with amorphous electron-dense material (Fig la). Tangential sections through the E.R. membrane profile show that the ribosomes 
have a spiral shape. On the other hand most of the ribosomal material is largely scattered over the whole cytoplasm from the perinuclear region up to the cell periphery. In the intact cell the cytoskeleton organization is hardly detectable. However, intermediate-sized filaments (IF) are clearly visualized around the nuclei and spread all over the cytoplasm forming loose bundles. Microtubules as well are visible without any particular distribution being mostly randomly scattered. Very difficult is the detection of the pattern of thin actin filaments. The most evident feature is that in many cells but not in all, a rather compact filamentous meshwork is found in close proximity to the plasma membranes or comprized within the core of cell surface microvilli. In other cytoplasmic regions a thin filament meshwork is found in areas filled by polyribosomes.

If the cells from the suspension culture are gently extracted by Triton X-100 (Fig 1b) then the abundance of IF as well as microfilaments is visualized (Fig $1 c, d$ ). In fact, from the nuclear envelope up to the plasma membrane an intricate meshwork of IF is seen. Clusters of ribosomes remain attached either to membrane profiles or to the microfilament-like structures (Fig le,f).

In spite of the fact that Triton-extraction solubilizes most of the membrane-lipids the plasma membrane after this treatment still appears as a continuous boundary, displaying a triple-layered aspect ${ }^{20}$. This latter feature is particularly evident where cytoplasmic condensations are closely associated to the plasma membrane (Fig 1c).

Retention of polyribosomes in lens cell cytoskeletal preparations

Electron microscopy provides some evidence that polyribosomes in lens cells are attached to both microfilamentous and membranous structures. In order to provide biochemical evidence for these associations and to quantitate the relative amounts of polyribosomes associated with various cellular structures we used extraction procedures essentially as described by Lenk et al ${ }^{1}$. These include Triton X-100 extraction in an isotonic buffer as first step. With this treatment free polyribosomes are extracted and some other membrane constituents in particular lipids are almost completely removed, according to Lenk et $a \ell^{1,2}$. 


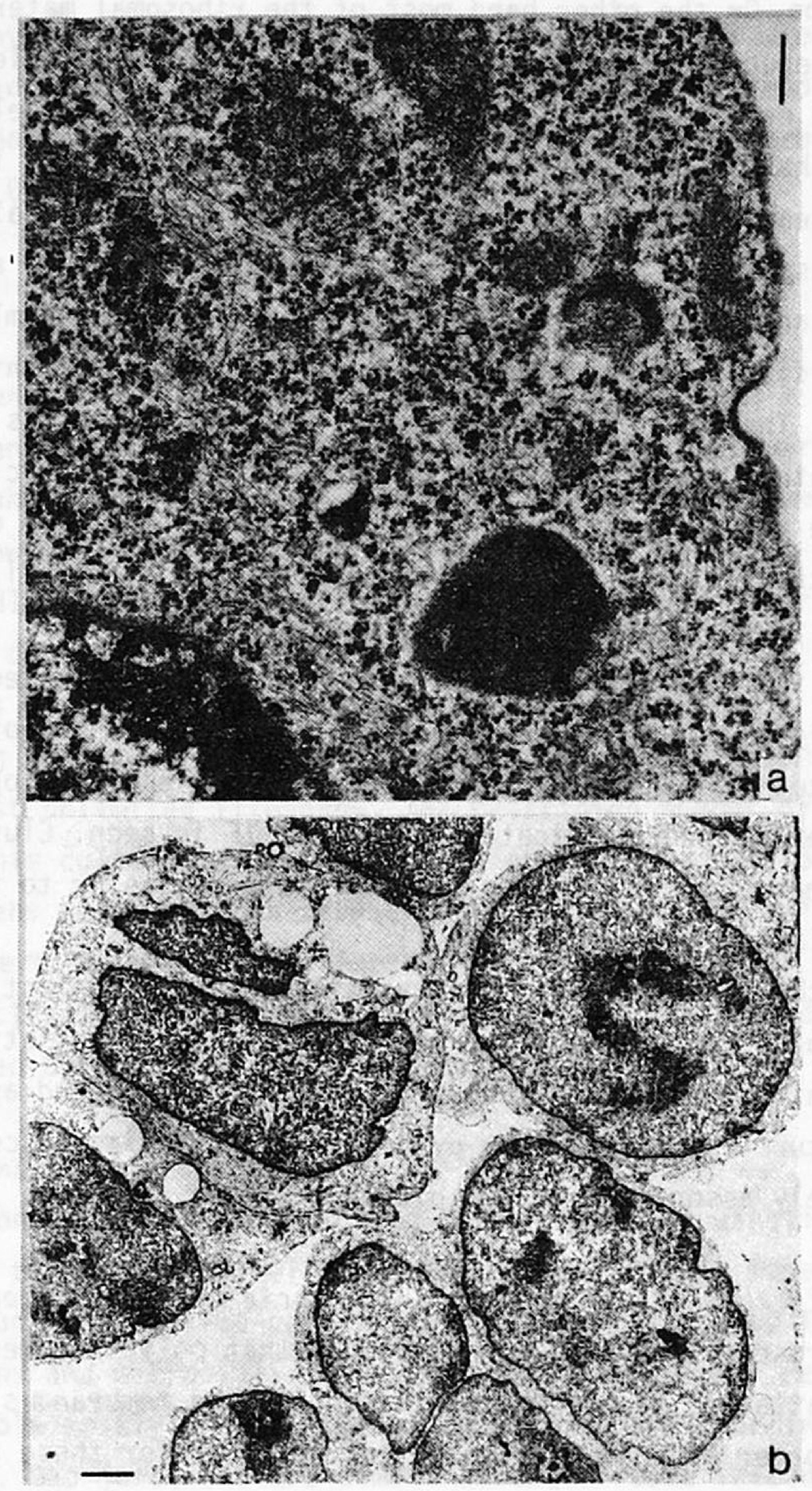

Fig 1 Transmission electron micrographs of cultured hamster lens cells

a) The cytoplasm close to the nucleus. Note spiral polyribosomes, partly attached to membranes and bundles of intermediate-sized filaments running in various directions. Bar indicates $500 \mathrm{~nm}$. b) Cells subjected to Triton X-100 treatment. Bar indicates $1 \mathrm{\mu m}$. 


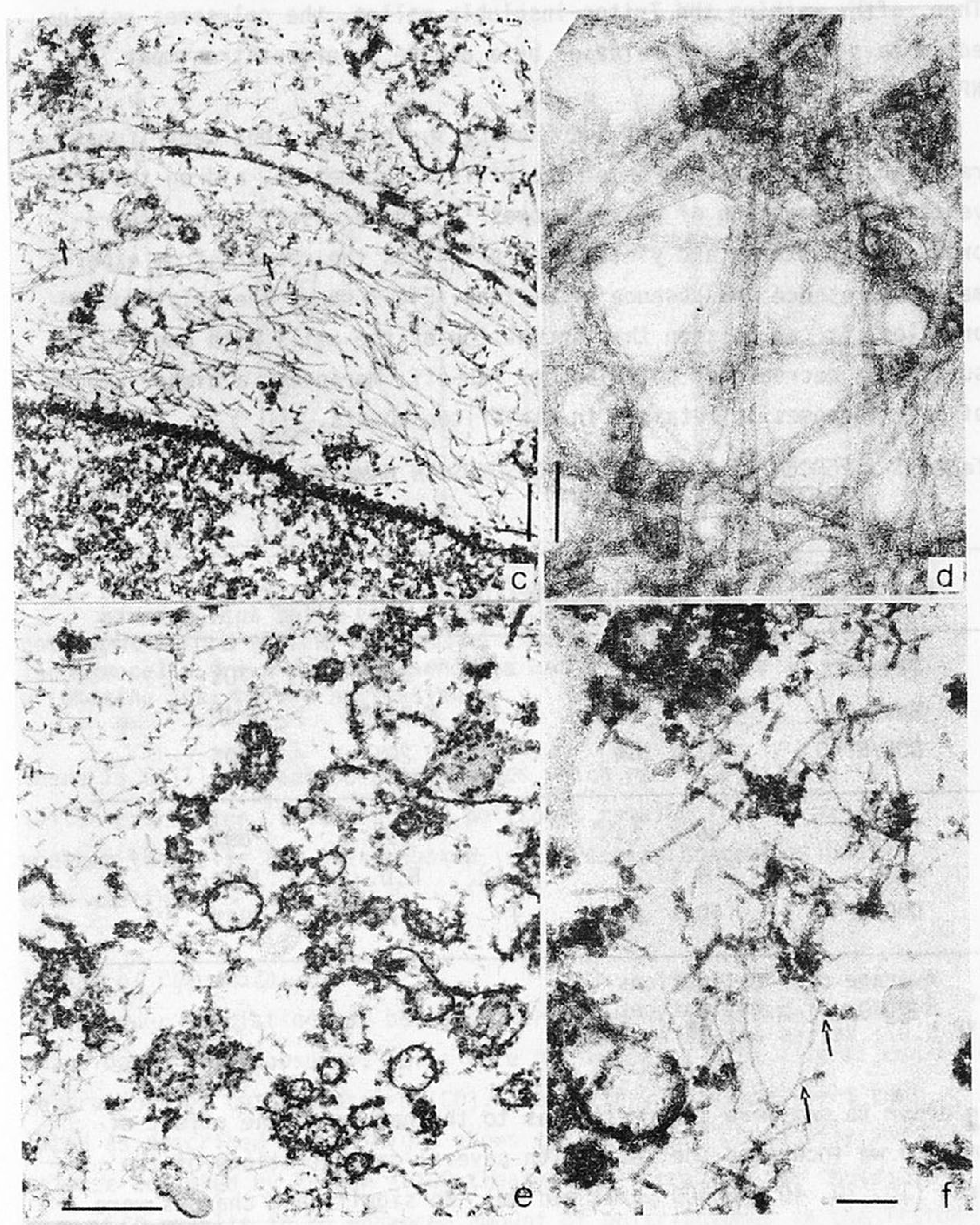

Fig 1 (continued)

c) Higher magnification of $b$. Thin 7-nm filaments are visible together with intermediate-sized filaments. Note that polyribosomal clusters remain attached to membrane profiles and to the microfilaments (arrows). Bar indicates $200 \mathrm{~nm}$.

d) High magnification of intermediate-sized filaments. Bar=50 nm.

e) Polyribosomes attached to endoplasmic reticulum membranes. Bar=200 nm.

f) Polyribosomes attached to microfilaments (arrows). Bar=100 nm. 
Then, after washing the Triton-insoluble pellet, the polysomes retained in this fraction are released by a double detergent treatment (DOC) NP40).

Analysis of the different fractions by sucrose gradient centrifugation revealed that preincubation of the cells with emetine, a drug that prevents disaggregation of polyribosomes ${ }^{21}$, was necessary to ensure reproducible patterns and yields. Table I gives the results from experiments in presence and absence of emetine. Fig 2 shows the polyribosome profiles. It can be seen that incubation of the cells with emetine results in a decrease of polyribosome run-off. Moreover, a higher amount of polyribosomes is retained in the Triton-ghosts.

Table I PERCENTAGES OF (POLY)RIBOSOMES IN HAMSTER LENS CELLS EXTRACTED WITH DETERGENTS

\begin{tabular}{lrccc}
\hline Extraction & $\begin{array}{c}\text { Percentage } \\
\pm \text { SEM }\end{array}$ & Emetine & 80 S & Polyribosomes \\
\hline $\begin{array}{l}\text { Triton } \\
\text { Wash }\end{array}$ & $7 \pm \pm 8 \%^{*}$ & - & $30 \%$ & $70 \%$ \\
DOC/NP40 & $41 \pm 10 \%$ & - & $20 \%$ & $80 \%$ \\
\hline Triton & $36 \pm 6 \%^{* *}$ & + & $11 \%$ & $89 \%$ \\
Wash & $4 \pm 2 \%$ & + & N.D. & N.D. \\
DOC/NP40 & $60 \pm 5 \%$ & + & $7 \%$ & $93 \%$ \\
\hline
\end{tabular}

* Average of 7 estimations

** Average of 5 estimations

*** N.D.: Values not determined

In order to get more information as to the nature of the effect of emetine we incubated the cells with several concentrations of the drug $(10,20,40$ and $100 \mu \mathrm{g} / \mathrm{ml}$ medium). No significant changes were seen in the amounts of polysomes in the lysis or cytoskeleton fraction. Aslight increase in polysomes released in the lysis was observed with increasing amounts of emetine (results not shown). Thus, even though emetine seems to slightly stabilize the interaction between polyribosomes and the cytoplasmic Triton-insoluble escafold, 

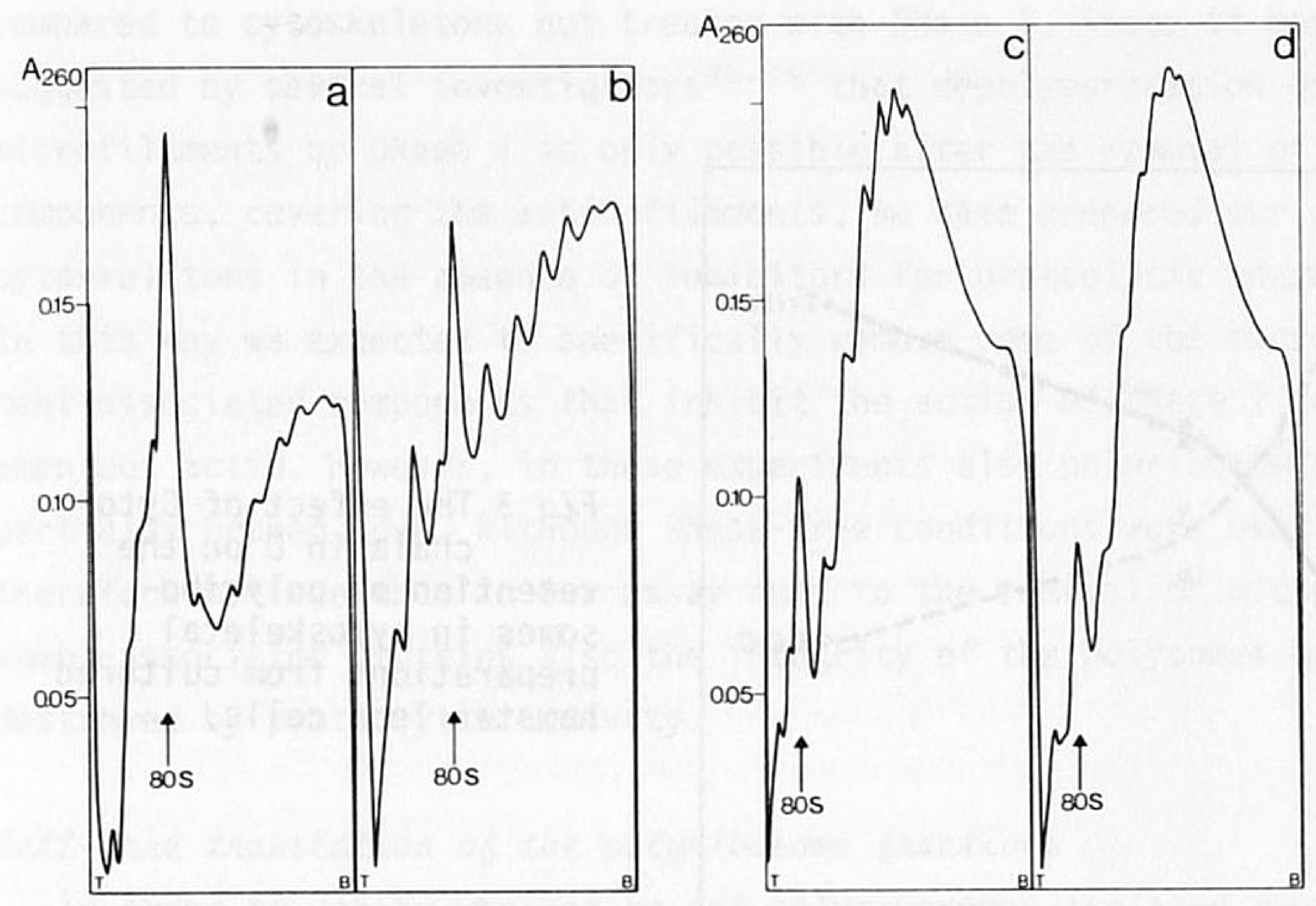

Fig 2 Polyribosome profiles of fractions isolated from cultured hamster lens cells by Triton X-100 ( $a$ and $c$ ) and a double detergent method (DOC/NP40; $b$ and $d)$. The polyribosomes were isolated from cells grown in the absence ( $a$ and $b$ ) or presence ( $c$ and $d$ ) of emetine just before harvesting.

there is still a fraction of polysomes which remain available to Triton-extraction. This class of polysomes remains free no matter whether the cells are preincubated in increasing concentrations with emetine.

\section{Effect of Cytochalasin D}

In order to distinguish between microfilament associated and membrane bound polyribosomes, cells were preincubated with several concentrations of Cytochalasin D (CD). Thereafter, polysomes were isolated as described above. Fig 3 shows the effect of $C D$ on polysome release achieved by Triton $X-100$ treatment. Increasing the concentration of CD results in an enhanced amount of polyribosomes in the Tritonfraction. Maximal release is obtained at a CD concentration of $6 \mu \mathrm{g}$ $\mathrm{CD} / \mathrm{ml}$ growth medium, while at higher concentrations (we have tested concentrations up to $20 \mu \mathrm{g} \mathrm{CD} / \mathrm{ml}$ medium) a slight decrease of the polysomal yield is observed. 


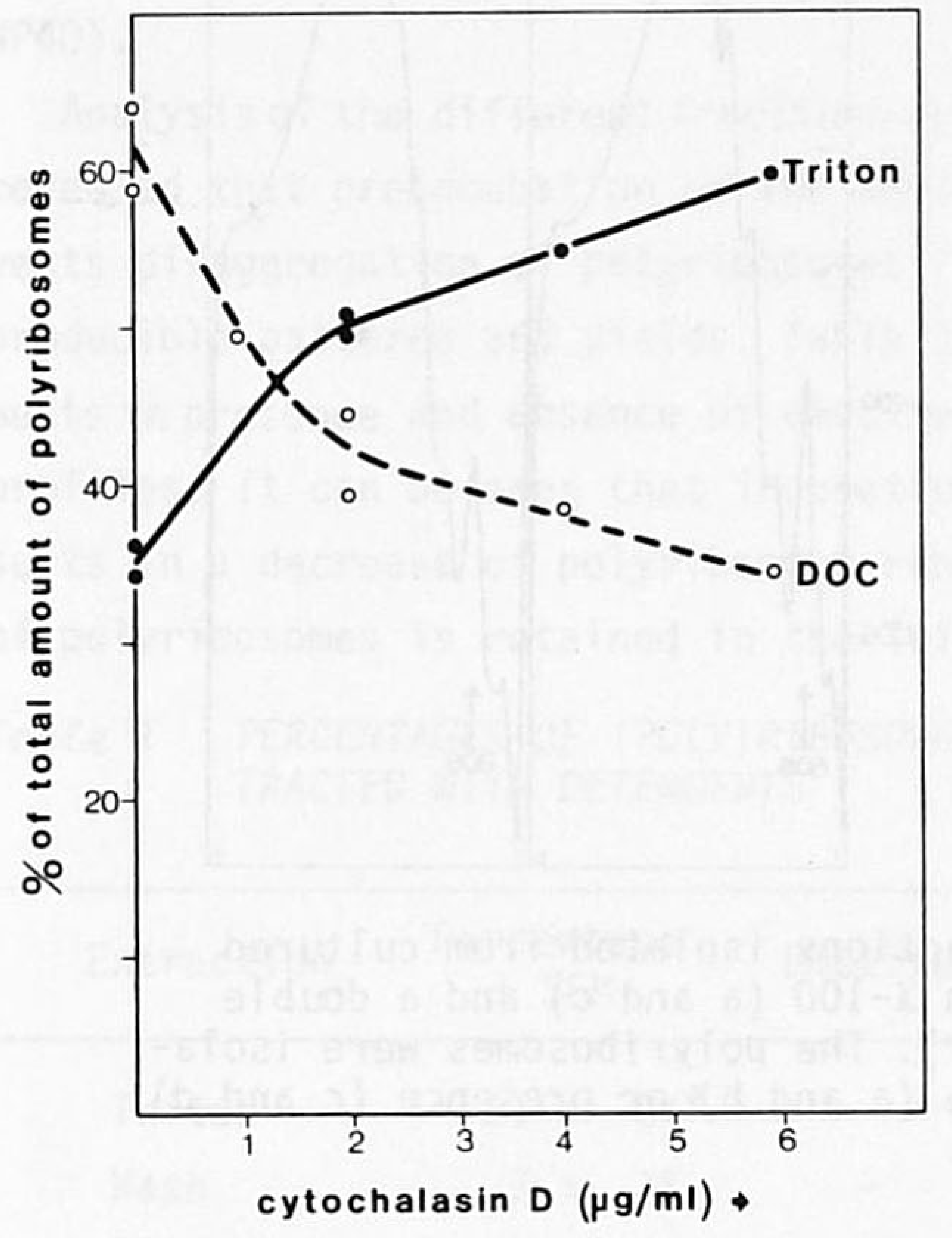

Fig 3 The effect of Cytochalasin $D$ on the retention of polyribosomes in cytoskeletal preparations from cultured hamster lens cells.

Emetine was used to prevent polyribosome dissociation. This could be confirmed by sucrose gradient centrifugation of both Triton - and DOC/NP40 - extracted polyribosomes.

More polyribosomes (about 25\%) can be released in the lysis-buffer (Triton $\mathrm{X}-100$ ) when the cells are preincubated with $C D$, suggesting that these polyribosomes are attached to structures that are destroyed by the drug. Since CD has been shown to specifically act on microfilaments 22 and is able to dissociate this cytoskeletal organisation, we assume that $25 \%$ of the polyribosomes in our cells are bound to microfilaments.

Incubation of the cytoskeletal structures (Triton-ghosts) with DNase I, which has also been shown to depolymerize microfilaments 23-26 did not result in release of a significant amount of polyribosomes. After DNase I incubation and subsequent washing the amounts of polysomes released by DOC/NP40 treatment were even slightly higher when 
compared to cytoskeletons not treated with DNase I. Since it has been suggested by several investigators $24-26$ that depolymerisation of microfilaments by DNase I is only possible after the removal of some components, covering the actin filaments, we have prepared our cellcytoskeletons in the absence of inhibitors for proteolytic enzymes. In this way we expected to specifically remove some of the microfilament-associated components that inhibit the action of DNase I on filamentous actin. However, in these experiments also polyribosomes were partially broken down, although RNase-free conditions were used. We therefore believe that in our assay next to the removal of microfilament-associated proteins also the integrity of the polysomes may be destroyed by proteolytic activity.

\section{Cell-free translation of the polyribosome fractions}

In order to verify whether or not polyribosomes isolated from the two different fractions (lysis and DOC/NP40) code for specific polypeptides these polysomes were added to a reticulocyte cell-free translation system. For these experiments polyribosomes were isolated from cells not preincubated with emetine. After translation the radioactively labelled polypeptides were separated and analyzed on SDS-containing polyacrylamide gels and autoradiographed. Fig 4 shows the pattern of polypeptides synthesized under the direction of polyribosomes isolated from the lysis fraction (Fig 4, lane a) and those released from the cell pellet by the double detergent method (Fig 4, lane b).

It can be seen that both fractions give similar results. The main products synthesized de novo are actin and a protein in the $35 \mathrm{kD} \mathrm{mol}$ weight region. Next to these major components other polypeptides among which the cytoskeletal constituents vimentin and tubulin, are synthesized in lower amounts. The identity of the proteins is confirmed by 2D-gel electrophoresis. This technique also revealed that no crystallin polypeptides are made.

From these results it is not easily apparent if attachment to the cytoskeleton is paralled by any specificity with respect to the translation products as shown for lens fiber polysomes ${ }^{8}$. 


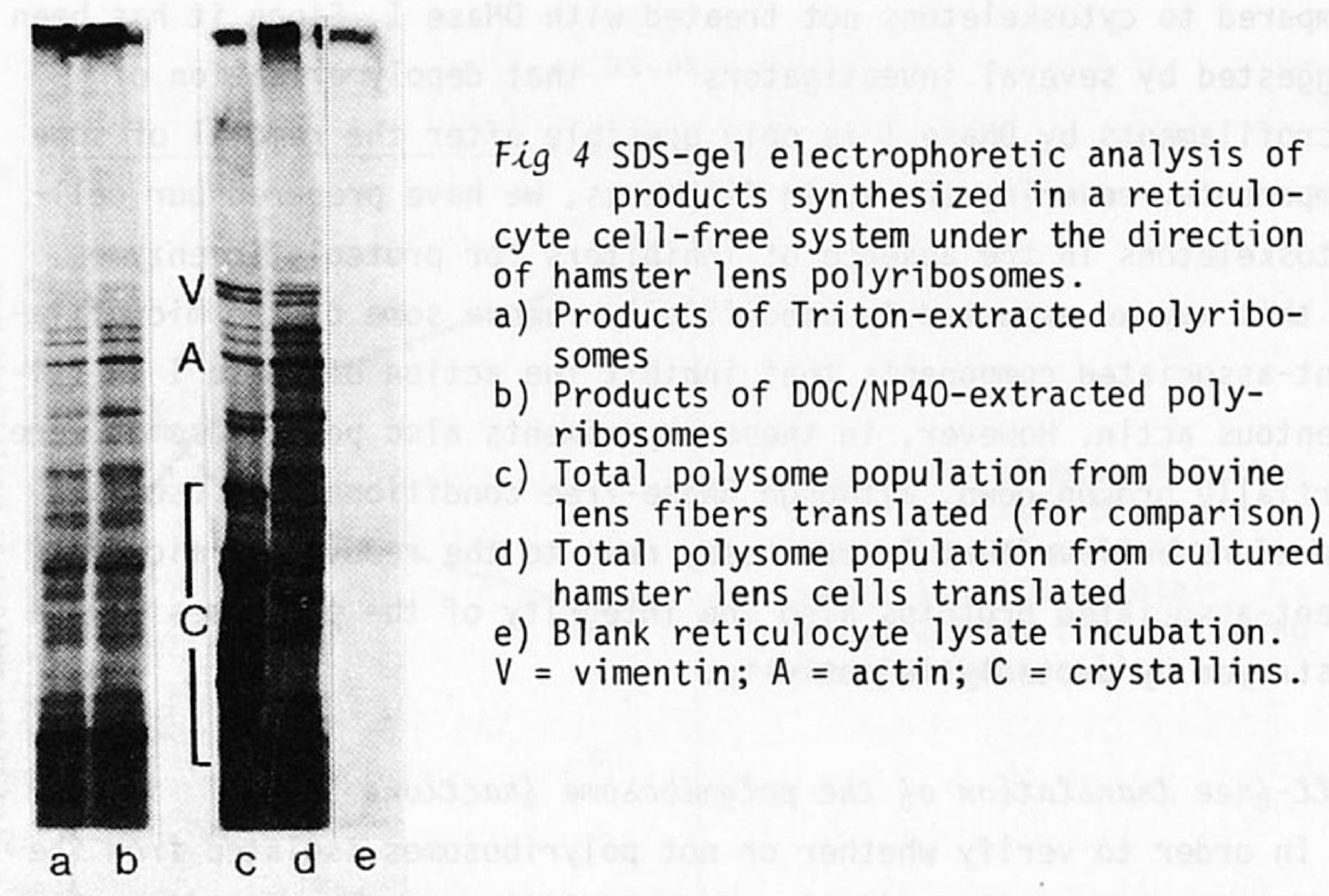

\section{DISCUSSION}

In this chapter evidence is provided for an intimate association of polyribosomes with microfilaments in cultured hamster lens cells.

Firstly, this is suggested by the fact that polyribosomes resist Triton-extraction. Secondly, in the electron microscope it can be shown that polysomes adhere to membranes and microfilaments. Thirdly, by using Cytochalasin D, a drug that specifically destroys microfilaments, it is shown that a significant amount of polyribosomes is released into the Triton-extractable fraction. Surprisingly, DNase I can not release polyribosomes from the lens cell cytoskeletal preparations, in contrast to our finding in lens fibers ${ }^{8}$ (see Chapter VII). However, steric hindrance may give an explanation for this failure of DNase I to depolymerize microfilaments, as found by other investigators $24-26$.

Sheetz ${ }^{24}$ suggests that proteolytic cleavage of a certain cytoskeletal component (for example tropomyosin or myosin) is a prerequisite for actin extraction and cytoskeleton disruption by $\mathrm{DNa}-$ se I. The removal of actin-binding proteins enables DNase I to bind to microfilaments and thereby to solubilize structural actin, 
releasing the attached polyribosomes. The removal of microfilamentassociated proteins is either achieved by incubating cells in a myosinextracting buffer, as shown for chick embryo connective tissue cells $\mathrm{s}^{25}$ or by internal cellular proteolytic activity when cytoskeletal preparations are incubated in a medium not containing inhibitors of proteolytic enzymes ${ }^{24}$. When this experiment is done with our cells then the yield of the polyribosomes associated with the Triton-insoluble fraction is consistently reduced, probably due to proteolytic breakdown of the cytoplasmic escafold and/or the ribosomal subunits. Under these circumstances, of course, we can not anticipate whether or not there exists still an effect of DNase I on the bulk of polyribosomes that is retained in the Triton-ghost.

Another striking result is, that in contradiction with observations made in HeLa-cells $\mathrm{s}^{1,2,3}$ and $\mathrm{KB}-\mathrm{cell} 1 \mathrm{~s}^{27}$, the yield of free polyribosomes is consistent in various experiments and seems not to be primarily dependent on the existence of breaks through the plasma membranes. In HeLa- and KB-cells Penman and coworkers ${ }^{1,2}, 3$ and van Venrooij et al ${ }^{27}$ show the retention of virtually all translatable RNA (i.e. polyribosomes) in the cytoskeletal preparation. Conversely, in the hamster lens epithelial cells free- and membrane-cytoskeleton bound polyribosomes are found which are translatable in a heterologous cell-free system. In order to assure that no polyribosomes are released from the cytoskeleton artificially by shearing, the integrety of the cytoskeletal preparations was verified in the electron microscope. It appeared that no significant destruction had taken place, indicating that our finding of $36 \%$ of free (poly)ribosomes is not artificially caused by the isolation procedure. Furthermore, cytoskeletal fragments with adhering polyribosomes released from the cells would sediment to the bottom of the sucrose gradients, as suggested for $\mathrm{KB}-\mathrm{cellls} \mathrm{s}^{27}$ and will thus not give rise to the typical polyribosome patterns as shown in Figs $2 \mathrm{a}$ and $2 \mathrm{c}$.

0ccasionally cells grown for 8-10 weeks were studied. These cells show a decreased mitotic activity as compared to younger cells and give low polyribosome yields while the relative amount of cytoskeleton-bound polysomes diminishes. This phenomenon was observed by biochemical methods as well as in the electron microscope ${ }^{9}$. These re- 
sults, together with the indication that the ratio of free and cytoskeleton-bound polysomes may vary with stabilizing conditions or by aging point to the existence of control mechanisms of the association which might play a role in the modulation of protein biosynthesis under different physiological conditions. For example, Toh et al28 report that in young fetal lung fibroblast monolayer cultures polyribosomes line up with the stress fibers (microfilament bundles). In more mature and better differentiated fetal lung fibroblasts, polyribosomes were found to be associated with endoplasmic reticulum and could therefore not be disrupted by pretreatment with Cytochalasin $B$. These findings should be kept in mind when comparing polyribosome distributions in different cell-types (for example HeLa, KB- and the hamster lens cells) or when comparing cells at different stages of development or differentiation (for example epithelial lens cultures and lens fibers).

Although several hypothesis have already been outlined as to the molecular mechanisms linking polyribosomes to the cytoskeletal framework, this question is not yet fully understood. Most of the evidence, including our results, point to an association of polysomes (mRNA) to microfilaments as concluded from electron microscopic observations and from experiments using microfilament disrupting drugs. It is rather surprising therefore that according to Zumbe and Trachse ${ }^{29}$ instead of actin filaments, intermediate filaments are assumed to be associated with the cap binding protein, a component that specifically binds to the $5^{\prime}$ cap structure of messenger RNA.

From these results it becomes clear that further investigations have to be carried out in order to get a better insight into still undetected functional differences between free, membrane-bound and cytoskeleton-associated polyribosomes as well as into the nature of the polyribosome-cytoskeleton interaction. 


\section{REFERENCES}

1. Lenk, R., Ransom, L., Kaufman, Y. and Penman, S., Cel1 10 (1977) 67.

2. Lenk, R. and Penman, S., Cell 16 (1979) 289.

3. Dreyfuss, G., Cervera, M. and Penman, S., Cell (1981) in press.

4. Wolosewick, J.J. and Porter, K.R., Am. J. Anat. 147 (1976) 303.

5. Wolosewick, J.J. and Porter, K.R., J. Cell Biol. 82 (1979) 114.

6. Bloemendal, H., Kibbelaar, M., Ramaekers, F.C.S., SeltenVersteegen, A.M.E., Dunia, I. and Benedetti, E.L. In: Prot. Biol. Fluids, Proc. 26th Colloquium (H. Peeters, Ed.) Pergamon Press, 0xford, Brussels, p 499.

7. Bloemendal, H., Benedetti, E.L., Ramaekers, F.C.S., Dunia, I., Kibbelaar, M. and Vermorken, A.J.M., Mol. Biol. Rep. 5 (1979) 99.

8. Ramaekers, F.C.S., Selten-Versteegen, A.M.E., Dunia, I., Benedetti, E.L. and Bloemendal, H., Proc. Natl. Acad. Sci. USA 77 (1980) 725.

9. Bloemendal, H., Lenstra, J.A., Dodemont, H., Ramaekers, F.C.S., Groeneveld, A.A., Dunia, I. and Benedetti, E.L., Exp. Eye Res. 31 (1980) 513.

10. Bloemendal, H., Ramaekers, F.C.S., Lenstra, J.A., Dodemont, H., Dunia, I. and Benedetti, E.L. In: Applied Methods in Oncology. Vol 3: The predictive value of short-term screening tests in carcinogenicity evaluation (Williams, G.M., Kroes, R., Waaijers, H.W., v.d. Poll, K.W., Eds.) Elsevier, Amsterdam (1980) pp 199.

11. Ramaekers, F.C.S. and Bloemendal, H. In: Molecular and Cellular Biology of the Eye Lens (H. Bloemendal, Ed.) Wylie and Sons, New York (1981) 85.

12. Ramaekers, F.C.S., Osborn, M., Schmid, E., Weber, K., Bloemendal, H. and Franke, W.W., Exp. Cell Res. 127 (1980) 309.

13. Venrooij van, W.J., Groeneveld, A.A., Bloemendal, H. and Benedetti, E.L., Exp. Eye Res. 18 (1974) 517.

14. Smith, G.K., Schray, K.J. and Schaffer, S.W., Biochemistry 84 (1978) 406.

15. Palmiter, R.D., Biochemistry 13 (1974) 3606. 
16. Bloemendal, H., Schoenmakers, J., Zweers, A., Matze, R. and Benedetti, E.L., Biochim. Biophys. Acta 123 (1966) 217.

17. Pelham, H.R.B. and Jackson, R.J., Eur. J. Biochem. 67 (1976) 247.

18. O'Farrel1, P.H., J. Biol. Chem. 250 (1975) 4007.

19. Mungyer, G. and Jap, P.H.K., Interdiscipl. Topics Geront. 12 (1978) 13, Karger, Basel (Hahn, H.P.V., Ed.).

20. Ben Ze'ev, A., Duerr, A., Solomon, F. and Penman, S., Cell 17 (1979) 859.

21. Grollman, A.P., J. Biol. Chem. 243 (1968) 4082.

22. Tanenbaum, S.W. (Ed.), Cytochalasins, Biochemical and Cell Biological Aspects, North Holland, Amsterdam (1978).

23. Lazarides, E. and Lindberg, U., Proc. Nat1. Acad. Sci. 71 (1974) 4742.

24. Sheetz, M., J. Cell Biol. 81 (1979) 266.

25. Raju, T.R., Stewart, M. and Buckley, I.K., Eur. J. Cell Biol. 17 (1978) 307.

26. Hitchcock, S.E., Carlsson and Lindberg, U., J. Cell Biol. 67 (1975) 1729.

27. Venrooij van, W.J., Sillekens, P.T.G., Eekelen van, C.A.G. and Reinders, R.J. (1981) submitted for publication.

28. Toh, B.H., Lolait, S.J., Mathy, J.P. and Baum, R., Eur. J. Cell Biol. 22 (1980) 376.

29. Zumbé, A. and Trachsel, H., Eur. J. Cell Biol. 22 (1980) 376. 
CHAPTER VII

POLYRIBOSOMES ASSOCIATED WITH MICROFILAMENTS IN LENS FIBERS.

IN VITRO SYNTHESIS OF THE MAJOR LENS MEMBRANE PROTEIN

The results described in this chapter have been published:

F.C.S. Ramaekers, A.M.E. Selten-Versteegen, I. Dunia, E.L. Benedetti

and H. Bloemendal, Proc. Nat1. Acad. Sci. USA 77 (1980) 725-729. 
CHAPTER VII

POLYRIBOSOMES ASSOCIATEO WITH MICROFILAMENTS IN LENS FIBERS. IN VITRO SYNTHESIS OF THE MAJOR LENS MEMBRANE PROTEIN

SUMMARY

The biosynthetic activity of a polyribosomal fraction isolated from the lens fiber plasma membrane - cytoskeleton complex by DNase I treatment has been assayed. After translation of these polyribosomes in a reticulocyte cell-free system and product analysis by electrophoresis in sodium dodecylsulphate-containing gels, the preferential synthesis of a protein with an apparent molecular weight of 26,000 was observed. We showed by means of immunochemical characterization that this protein, which seems not to be synthesized by 'free' polyribosomes, is identical with the major intrinsic plasma membrane protein MP26 of lens fibers. Upon storage, the molecular weight of the newly synthesized protein decreases to about 22,000, a phenomenon which has previously been observed for MP26 in isolated plasma membranes and which may be caused by the presence of a specific proteolytic cleaving site in the protein.

\section{INTRODUCTION}

The mammalian eye lens is a very suitable system for the study of terminal differentiation. During this process a great amount of plasma membrane constituents is newly synthesized, among which an intrinsic plasma membrane protein, designated earlier MP26 ${ }^{1}$. Almost $90 \%$ of the lens protein is contributed by the so-called crystallins ${ }^{2}$. The remaining $10 \%$ consists of quantitatively minor lens proteins of which a number participates in essential structures such as plasma membranes ${ }^{3}$ and the cytoskeletal matrix ${ }^{4}$.

In a recent study Kibbelaar et $a l^{5}$ have proven that one of these proteins (MP42) is identical with actin. Previous observations provid- 
ed evidence that the lens cytoskeleton consists of $7 \mathrm{~nm}$ and $10 \mathrm{~nm}$ filaments that end to the cytoplasmic surface of the plasma membrane ${ }^{4}$. Furthermore, it was shown that ribosomes and crystallin aggregates were associated with the filaments. Upon incubation with DNase I a fraction of polyribosomes could selectively be released from the cytoskeleton ${ }^{4,6}$.

Although MP26 represents the major intrinsic protein in fiber plasma membranes, no lens fiber polyribosome population carrying the mRNA coding for this protein could be detected after application of the standardprocedure ${ }^{7}$. This is rather striking since polyribosomes that direct the synthesis of the other characteristic intrinsic membrane protein MP34 are obtained by this methodology ${ }^{8}$.

In the present paper we demonstrate that the reason for this failure was due to the fact that the polyribosome fraction, preferentially synthesizing MP26, is not 'free' but seems to be associated with the plasma membrane-cytoskeleton complex in lens fibers.

\section{MATERIALS AND METHODS}

Calf eyes were obtained on ice from the slaughterhouse and used immediately. They were washed with distilled water and opened at the lateral side, so that the lenses could be removed without adhering iris material. Also the capsule and epithelial cells were removed. $L-\left[{ }^{35} \mathrm{~S}\right]$-methionine (spec. act. $400 \mathrm{Ci} / \mathrm{mmol}$ ) was purchased from the Radiochemical Center (Amersham, England). DNase I was obtained from Sigma and did, under the conditions used, not show RNAse or protease activity.

\section{Preparation of plasma membranes for gel electrophoresis}

Lens fiber plasma membranes were isolated at room temperature in either $\mathrm{NaHCO}_{3}$-buffer (1 mM) or TKM-buffer ( $50 \mathrm{mM} \mathrm{Tris-HCl,} \mathrm{pH} \mathrm{7.4,} 25$ $\mathrm{mM} \mathrm{KCl}, 5 \mathrm{mM} \mathrm{MgAc}_{2}$ ) according to the procedure described previously ${ }^{9}$, using discontinuous sucrose gradients. After exhaustive washing in the respective buffers, the fractions were analyzed directly by SDS-gel electrophoresis. 
Preparation of free- and membrane-bound polyribosomes

Lens cortices were dissected and homogenized in TKM-buffer. The $10,000 \times \mathrm{g}$ supernatant of the homogenate was used for the isolation of free polyribosomes as described earlier ${ }^{7}$. Membrane-bound polyribosomes were isolated from the remaining plasma membrane pellet after exhaustive washing with TKM-buffer at room temperature. In these steps heparin $(1 \mathrm{mg} / \mathrm{ml})$ was added to the buffer. The release of polyribosomes could be achieved by incubating the membranes for $1 \mathrm{~h}$ at room temperature in either deoxycholate $(D O C)$ at a concentration of $1.5 \%$ or DNase I $(0.5 \mathrm{mg} / \mathrm{ml})$. In the DNase I incubation $2 \mathrm{mM} \mathrm{MnAc} 2$ was added. Incidentally phenylmethylsulfonylfluoride (PMSF) to a final concentration of $0.1 \mathrm{mM}$ was used in the incubation mixture. For a blanc incubation only TKM-buffer was used.

The $10,000 \times \mathrm{g}$ supernatants of the incubations were layered on a $2 \mathrm{M}$ sucrose cushion in TKM and centrifuged for $12 \mathrm{~h}$ at $100,000 \times \mathrm{g}$. The pellets were further purified either by $0.25 \%$ DOC-treatment and re-centrifugation on a $2 \mathrm{M}$ sucrose cushion in TKM, or by direct centrifugation on a 15-35\% linear sucrose gradient and subsequent concentration in a Ti-50 rotor. The purified polyribosomes were diluted in bi-distilled water to a concentration of $1 \mathrm{mg} / \mathrm{ml}$ (determined spectrophotometrically assuming an extinction coefficent of 13 at $260 \mathrm{~nm}$ ).

\section{Electron microscopy}

Electron microscopy was performed as described elsewhere ${ }^{9}$.

\section{Synthesis of lens protein in a reticulocyte lysate}

Rabbit reticulocytes were prepared as described by Evans and Lingre $1^{10}$ and 1 ysed by addition of water. A 30,000 $\times \mathrm{g}$ supernatant fraction of the lysed cells was used as cell-free system, and incubations were performed at $30^{\circ}$ for $1 \mathrm{~h}$. The reaction mixture contained per $\mathrm{ml}: 0.6 \mathrm{ml}$ of reticulocyte cell-free extract, 1 umol ATP, 0.2 umol GTP, 1 umol dithioerythritol (DTT), $10 \mu \mathrm{mol}$ creatine phosphokinase, $20 \mu \mathrm{mol}$ Tris- $\mathrm{HCl}, \mathrm{pH} 7.4,100 \mu \mathrm{mol} \mathrm{KCl}, 1 \mu \mathrm{mol} \mathrm{MgAc}_{2}$, and 0.1 $\mu \mathrm{mol}$ of each of the naturally occurring amino acids $\left(40 \mu \mathrm{Ci}\right.$ of $\left[{ }^{35} \mathrm{~S}\right]$ methionine).

Polyribosomes were added in a concentration of 20-200 $\mathrm{\mu g}$ per $\mathrm{ml}$. 
The incubations were either directly used for gel electrophoretic analysis, immunoprecipitation, or stored at $-20^{\circ}$ for 3 weeks and thereafter analyzed.

\section{Immunoprecipitation of MP26}

The MP26 was cut out of a preparative SDS-polyacrylamide gel and antibodies against this protein were raised in a rabbit according to Alcala and Maisel ${ }^{11}$. Detection of MP26 in reticulocyte lysates was performed using this antiserum according to the procedure described by van Zaane et al ${ }^{12}$. Immunoprecipitates were analyzed by SDS-polyacrylamide gel electrophoresis.

\section{Polyacrylamide gel electrophoresis}

The translation products were analyzed by SDS-gel electrophoresis according to Laemmli $i^{13}$ with the modification that a gel slab instead of rods was used. The slab was $12 \mathrm{~cm}$ long and contained $13 \%$ acrylamide, $0.35 \%$ methylene-bisacrylamide and $0.1 \%$ sodium dodecylsulphate. In this method a stacking gel was applied. Staining and destaining were performed as described by Weber and 0sborn ${ }^{14}$. For the detection of the labelled proteins the procedure of Bonner and Laskey ${ }^{15}$ was used in combination with the drying procedure described by Berns and Bloemendal16.

\section{RESULTS}

Isolation of plasma membranes under conditions that stabilize cytoskeletal structures

Plasma membranes from lens fiber cells were isolated at room temperature under ionic conditions that stabilize both polyribosomes and the cytoskeletal structure. Figure 1 shows an SDS-gel electrophoretic protein pattern of membrane fractions that have been isolated either under cytoskeleton-destabilizing $\left(\mathrm{NaHCO}_{3}\right)$ or stabilizing (TKM) conditions. $\mathrm{NaHCO}_{3}$-isolated plasma membranes show as main protein constituent MP26, next to $\alpha$-crystallin and other components among which MP34, MP45 and MP55.

After isolation of membranes in TKM buffer the cytoskeleton is 


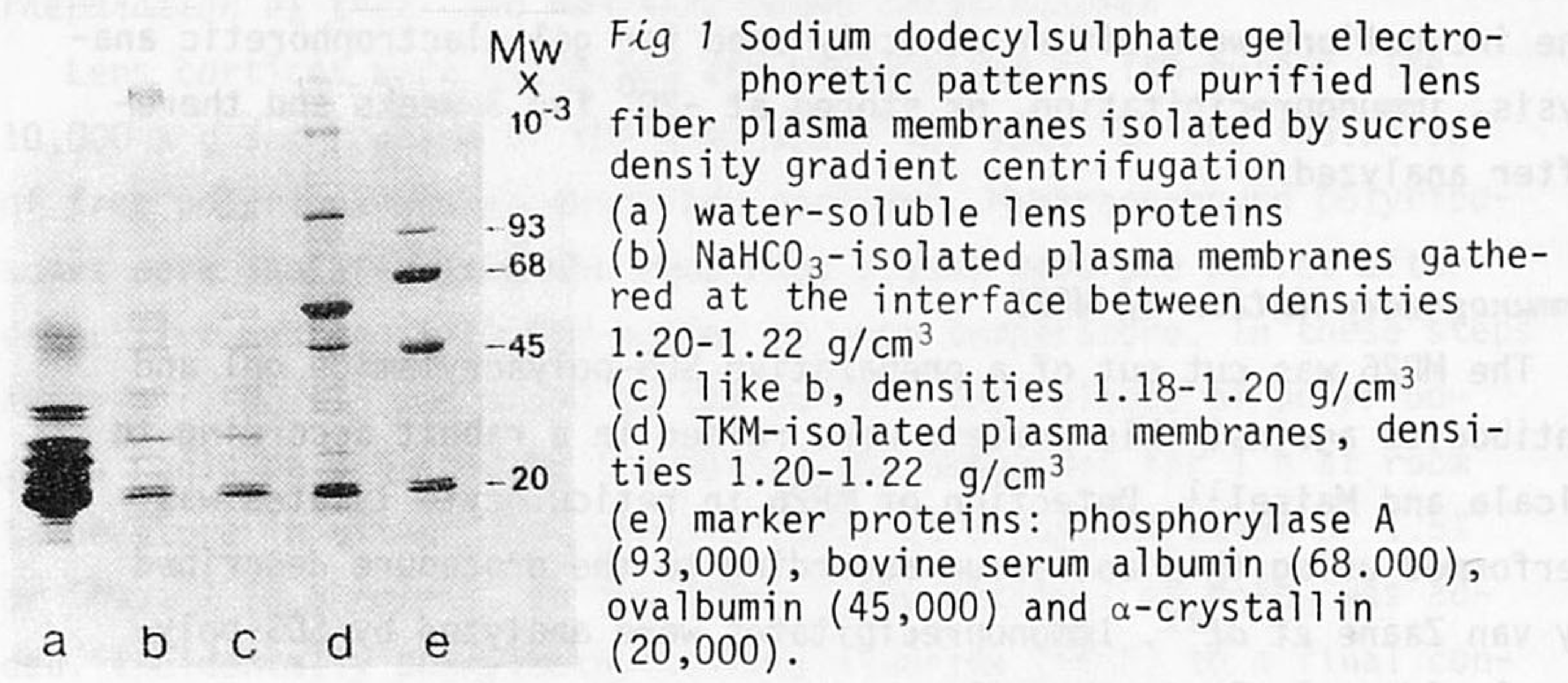

still attached (compare Fig 1d). It can be seen that two polypeptide fractions in the MP45 and MP55 region are greatly enriched in those preparations. One of the polypeptides with an apparent molecular weight of 43,000 has been identified as actin ${ }^{5}$. MP55 previously designated by us as a desmin-like protein has now been characterized and appears to be of the so-called vimentin type, a major constituent of intermediate filaments.

The cytoskeleton is released from the membranes when neither magnesium nor potassium ions are used in the isolation buffer. In this case only traces of actin and vimentin are observed in the electrophoretic pattern (Fig 1b, c).

Isolation of polyribosomes associated with the plasma membrane-cytoskeleton complex

The polyribosomes released from the plasma membrane-cytoskeleton complex either by deoxycholate or DNase I treatment were put on a continuous sucrose gradient and centrifuged as described in Materials and Methods. The profiles shown in Fig 2 were obtained. After a control incubation containing neither DOC nor DNase I no polysomal pattern was observed.

Sucrose gradient profiles of polyribosomes isolated after DOC or DNase I treatment are virtually identical. A slightly higher 80 s peak is seen when the polyribosomes were isolated by DOC treatment. In both cases the ratio A260/A280 increased up to 1.70 during isolation. Electron microscopy of the pellet obtained after DNase I treatment shows 


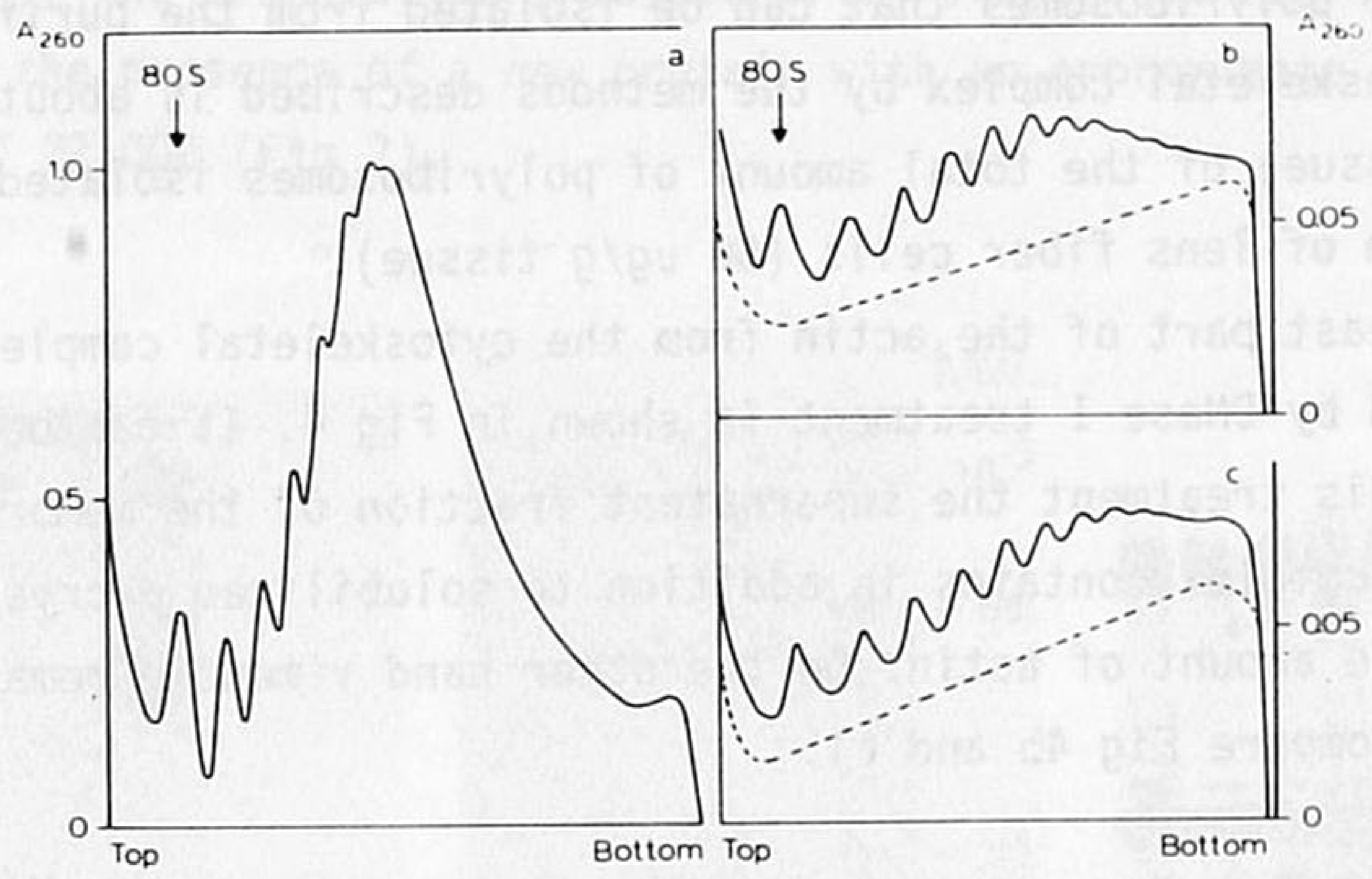

Fig 2 Sedimentation profiles of different polyribosomes preparations

(a) free lens fiber polyribosomes

(b) polyribosomes isolated by DOC-treatment

(c) polyribosomes obtained after DNase I treatment

(----) base-line of absorbance

the presence of arrays of monosomes attached to a thin strand. Morphologically these polyribosomes are undistinguishable from 'free' lens polyribosomes (Fig 3).

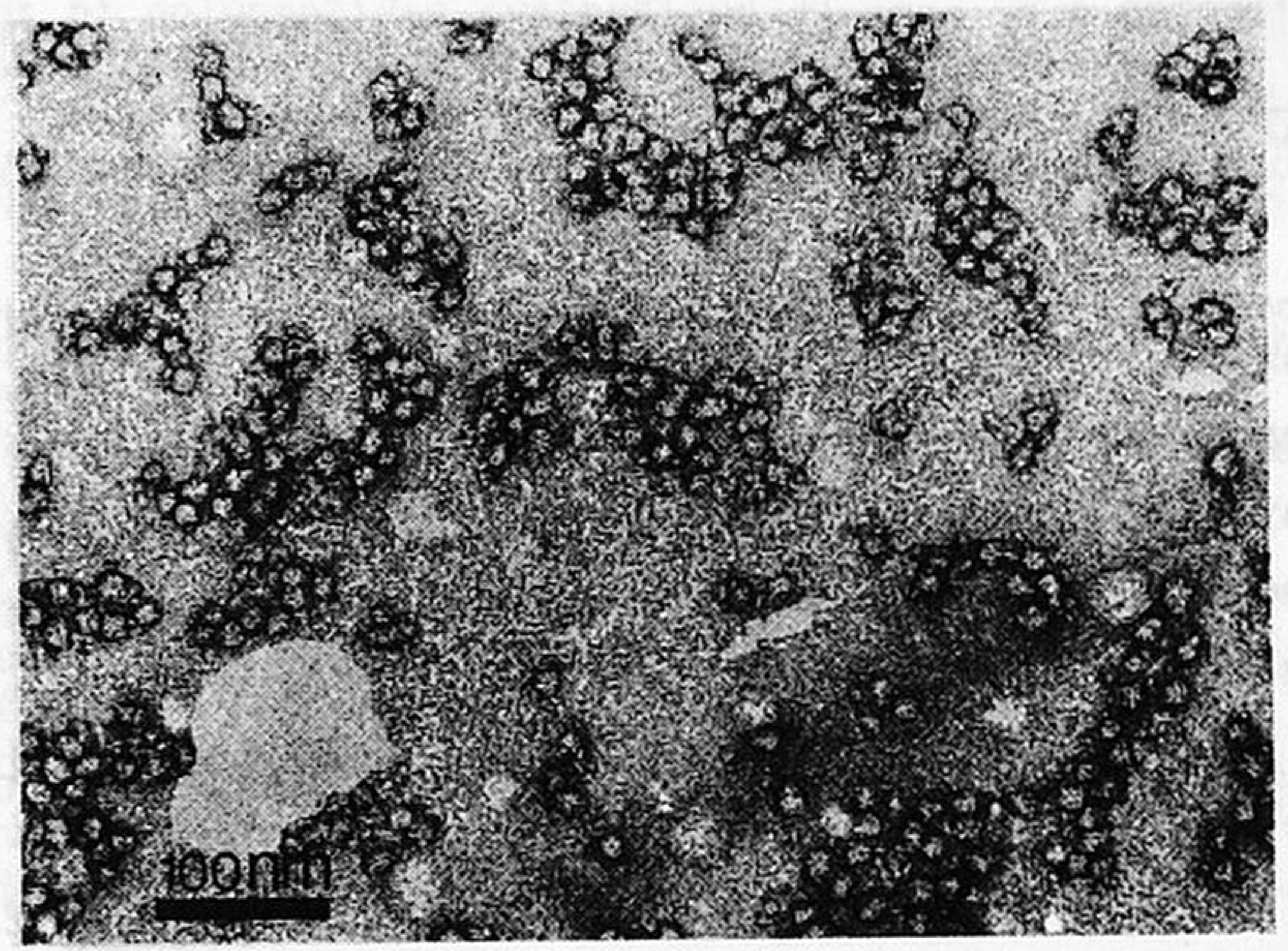

Fig 3 Negatively stained preparation of cytoskeleton-bound lens polyribosomes released by DNase I treatment. The grid was washed once with $1 \%$ deoxycholate before staining. 
The amount of polyribosomes that can be isolated from the purified membrane cytoskeletal complex by the methods described is about $1 \%$ $(0.5 \mathrm{\mu g} / \mathrm{g}$ tissue) of the total amount of polyribosomes isolated from the cytoplasm of lens fiber cells $(60 \mu \mathrm{g} / \mathrm{g}$ tissue).

That at least part of the actin from the cytoskeletal complex is depolymerized by DNase I treatment is shown in Fig 4. It can be seen that after this treatment the supernatant fraction of the membrane cytoskeletal complex contains in addition to solubilized $\alpha$-crystallin a considerable amount of actin. On the other hand vimentin remains in the pellet (compare Fig $4 b$ and $c$ ).

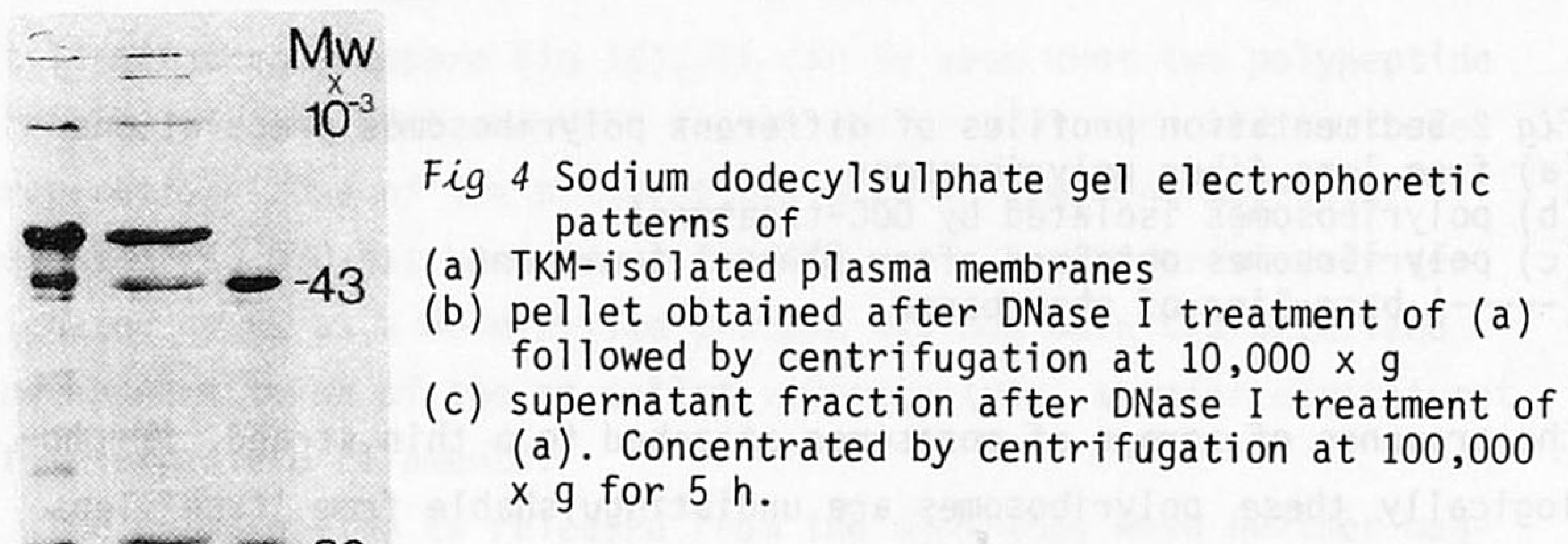

$z=-20$

a $\quad b \quad c$

Translation products of the isolated polyribosomes in a reticulocyte cell-free system

Translation of the isolated membrane-bound polyribosomes in a reticulocyte lysate and subsequent product-analysis by SDS-polyacrylamide gel electrophoresis revealed the preferential synthesis of a protein with a molecular weight of approximately 26,000 (Fig 5).

This result was obtained with polyribosomes, released from the membrane cytoskeletal complex either by DOC or DNase I treatment, provided the latter were re-run through a gradient or washed with $0.25 \%$ DOC. The identity of this protein with MP26, the main intrinsic plasma membrane protein of lens fibers, could be confirmed by immunoprecipitation using an antiserum directed against MP26 (Fig 6). 
Analysis of the translation products after storage at $-20^{\circ} \mathrm{C}$ for 3 weeks revealed the presence of a new protein with an approximate molecular weight of 22,000 (Fig 7 ).

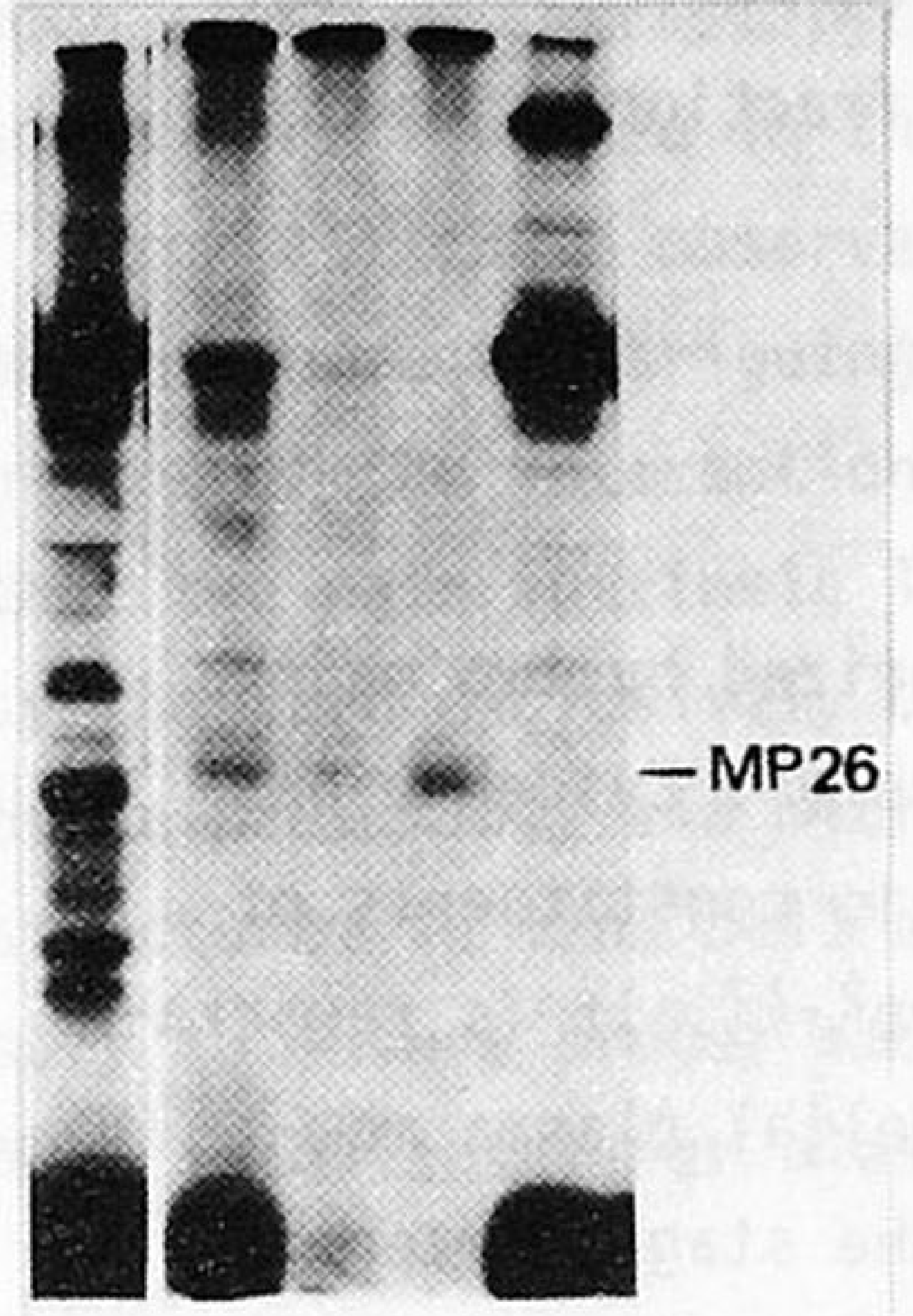

$a$ b c d e

Fig 5

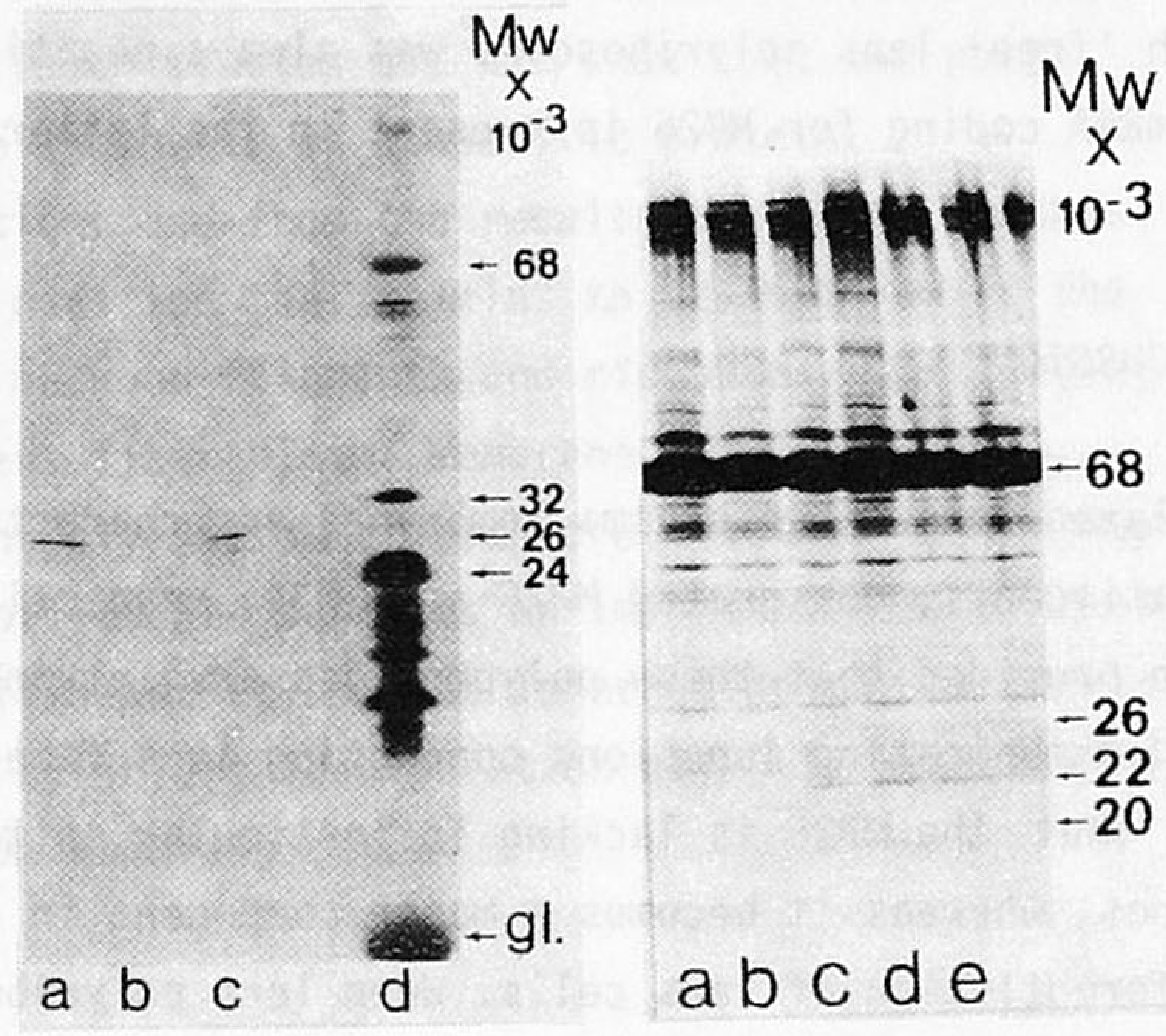

Fig 6
Fig 7

Fig 5 Autoradiograph of sodium dodecylsulphate gel electrophoretic patterns of polypeptides synthesized de novo in a reticulocyte cel1free system under direction of lens fiber polyribosomes

(a) 'free' polyribosomes

(b-d) polyribosomes isolated after DNase I treatment (50, 100 and 200 $\mu \mathrm{g} / \mathrm{ml}$, respectively)

(e) blanc incubation

Fig 6 Autoradiograph of sodium dodecylsulphate gel electrophoretic patterns of

(a) MP26 immunoprecipitate of a reticulocyte lysate incubated with DNase I-isolated polysomes

(b) as (a), incubation with 'free' polysomes

(c) as (a), incubation with DOC-isolated polysomes

(d) polypeptides synthesized in a reticulocyte lysate under the direction of 'free' lens fiber polyribosomes

Fig 7 Autoradiograph of sodium dodecylsulphate gel electrophoretic patterns of polypeptides formed in a reticulocyte lysate under direction of DNase I-isolated polyribosomes and after subsequent storage at - 200 for 3 weeks.

(a-e) polyribosome concentrations added were $0,2,5,10$ and $25 \mu \mathrm{g} / \mathrm{ml}$, respectively. 
This finding is in agreement with the observed gradual disappearance of MP26 in isolated lens fiber plasma membranes upon storage. Also in this case the concomitant formation of a protein with a molecular weight of 22,000 designated earlier MP22 has been reported ${ }^{1}$. Immunoprecipitation of the translation products obtained after incubation with 'free' lens polyribosomes was always negative, indicating that no mRNA coding for MP26 is present in the latter fraction.

\section{DISCUSSION}

Isolated lens fiber plasma membranes are characterized by two major constituents, designated MP26 and MP34, respectively ${ }^{1}$. Evidence has been provided that these polypeptides are intrinsic constituents of the communicating junctions connecting lens fibers ${ }^{2}, 17$. It is remarkable that the MP26 is lacking in lenticular epithelial plasma membranes, whereas it becomes a major component in the stage of terminal differentiation of lens cells. When lens polyribosomes prepared according to the standard procedure ${ }^{7}$ were translated in a heterologous cell-free system, only MP34 could be detected among the newly synthesized lens polypeptides. We wondered why such an important marker of cell differentiation as MP26 was not found as a translation product. One of the explanations was that we might have lost a specific population of polyribosomes as a consequence of the isolation procedure applied.

In most other systems polysomes occur either 'free' or as membranebound structures, each class being involved in the biosynthesis of specific proteins ${ }^{18}$. Albeit the endoplasmic reticulum is not present in lens fibers, a certain class of polysomes seems to be associated with the plasma membrane-cytoskeleton complex ${ }^{4}, 6$. The present study demonstrates, by means of biochemical techniques, that under proper conditions these polyribosomes are isolated together with the plasma membrane-cytoskeleton complex and can be released after DNase I treatment. Since DNase I has been shown to specifically depolymerize actin filaments ${ }^{19}$, our finding that treatment of the cytoskeletal complex with this enzyme releases polyribosomes strongly supports the idea 
that part of the polyribosomes in lens fibers is attached to the actincontaining microfilaments.

Interaction between (poly)ribosomes and cytofilaments has also been postulated by other investigators in Hela cells $\mathrm{s}^{20,21}$, acrosomes ${ }^{22}$, ascites cells $\mathrm{s}^{23}$, cultured fibroblasts and kidney cells $\mathrm{s}^{24}$ mainly based upon electron microscopy. These studies did not show that the polysomes were involved in the synthesis of a specific protein.

From all these observations and from the results presented in this paper the most intriguing question that remains to be answered is the nature of the interaction between filaments and ribosomes. Our finding that the main intrinsic lens fiber plasma membrane protein MP26 is synthesized exclusively on polyribosomes which are attached to the membrane presumably via microfilaments suggests an important role of these structures in lens cell differentiation. The interaction may be necessary to ensure proper and efficient incorporation of newly synthesized MP26 into lens fiber plasma membranes. 


\section{REFERENCES}

1. Bloemenda1, H., Vermorken, A.J.M., Kibbelaar, M., Dunia, I. and Benedetti, E.L., Exp. Eye Res. 24 (1977) 413.

2. Bloemendal, H., Science 197 (1977) 127.

3. Bloemendal, H., Zweers, A., Vermorken, F., Dunia, I. and Benedetti, E.L., Cell Diff. 1 (1972) 91.

4. Bloemendal, H., Kibbelaar, M., Ramaekers, F.C.S., SeltenVersteegen, A.M.E., Dunia, I. and Benedetti, E.L. (1978). In: Prot. Biol. Fluids, Proc. 26th Colloq., Brussels (H. Peeters, Ed.). Pergamon Press, 0xford, 499.

5. Kibbelaar, M., Selten-Versteegen, A.M.E., Dunia, I., Benedetti, E.L. and Bloemendal, H., Eur. J. Biochem. 95 (1979) 543.

6. Benedetti, E.L., Dunia, I., Cartaud, U., Hatae, I., Favard-Sereno, C., Benzel, C., Kibbelaar, M. and Bloemendal, H. (1978). In: IId Colloquium Hormones and Cell Regulation (Dumont, J.E. and Nunez, J., Eds.). Elsevier North Holland, 2, 305.

7. Bloemendal, H., Schoenmakers, J., Zweers, A., Matze, R. and Benedetti, E.L., Biochim. Biophys. Acta 123 (1966) 217.

8. Vermorken, A.J.M., Hilderink, J.M.H.C., Dunia, I., Benedetti, E.L. and Bloemendal, H., FEBS Letters 83 (1977) 301.

9. Dunia, I., Sen Gosh, C., Benedetti, E.L., Zweers, A. and Bloemendal, H., FEBS Letters 45 (1974) 139.

10. Evans, M.I. and Lingrel, J.B., Biochemistry 8 (1969) 829.

11. Alcalá, I. and Maisel, H., Exp. Eye Res. 26 (1978) 219.

12. Zaane van, D., Gielkens, A.L.J., Dekker-Michielsen, M.J.A. and Bloemers, H.P.J., Virology 67 (1975) 544.

13. Laemmli, U.K., Nature 227 (1970) 680.

14. Weber, K. and Osborn, M., J. Biol. Chem. 244 (1969) 4406.

15. Bonner, W.M. and Laskey, R.A., Eur. J. Biochem. 146 (1974) 83.

16. Berns, A.J.M. and Bloemendal, H. (1974). In: Methods in Enzymology (Academic Press, New York-London) Vol. XXX, 675.

17. Benedetti, E.L., Dunia, I., Bentzel, C.J., Vermorken, A.J.M., Kibbelaar, M. and Bloemendal, H., Biochem. Biophys. Acta 457 (1976) 353 . 
18. Bloemendal, H., Benedetti, E.L. and Bont, W.S. (1974). In: Methods in Enzymology (Acad. Press New York-London) Vol. XXX, 313.

19. Lazarides, E. and Lindberg, U., Proc. Natl. Acad. Sci. USA 71 (1974) 4742 .

20. Lenk, R., Ransom, L., Kaufmann, Y. and Penman, S., Cell 10 (1977) 67.

21. Lenk, R. and Penman, S., Cell 16 (1979) 289.

22. Mollenhauer, H.H. and Morré, D.J., Science 200-(1978) 85.

23. Mosejev, V.V., Experientia 34 (1978) 1633.

24. Wolosewick, J.J. and Porter, K.R., J. Cell. Biology 82 (1979) 114. 


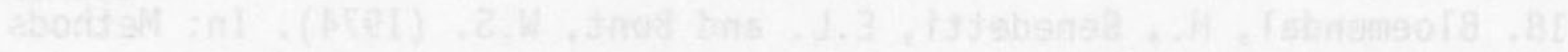

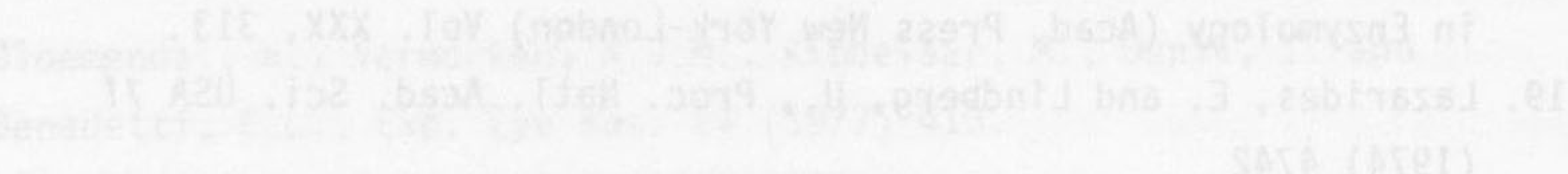

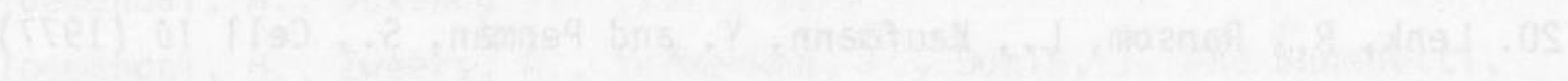

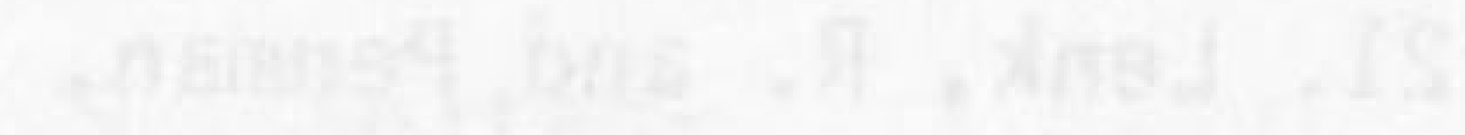

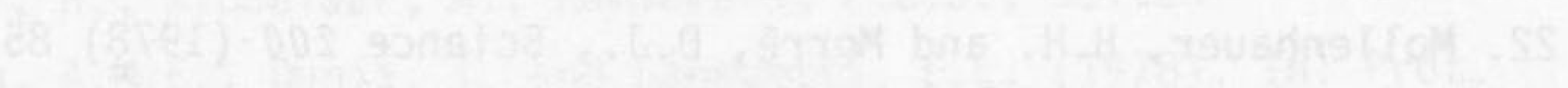


SUMMARY/SAMENVATTING

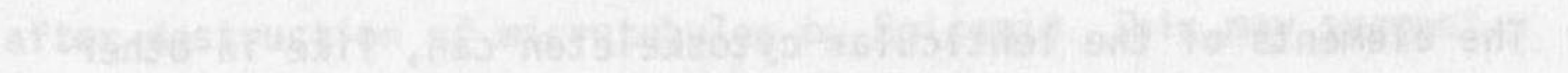

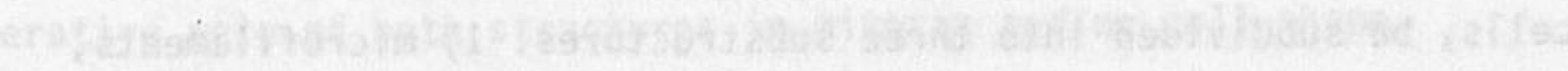

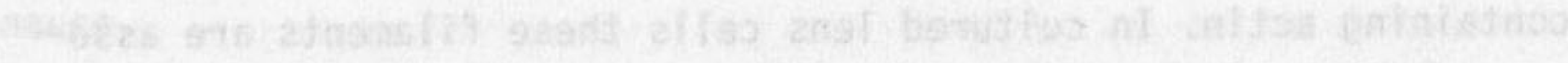

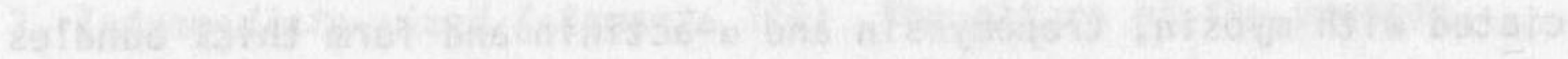

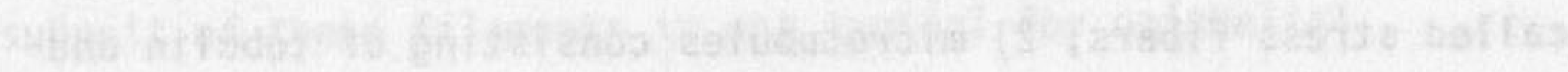

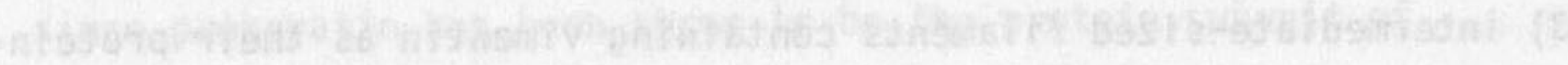

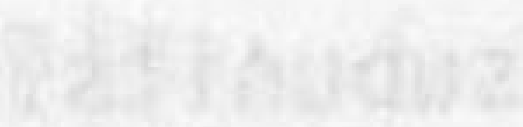

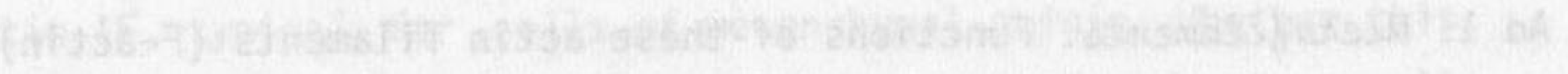

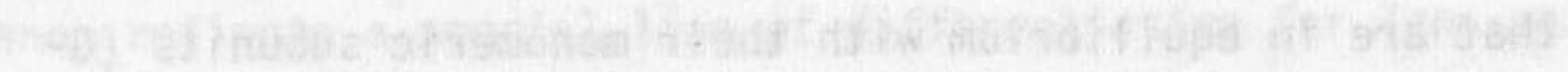

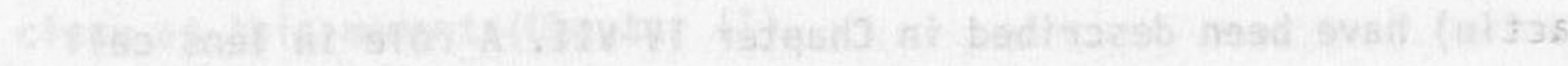

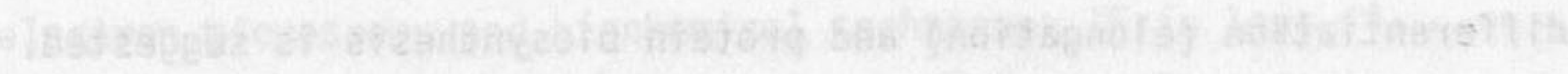

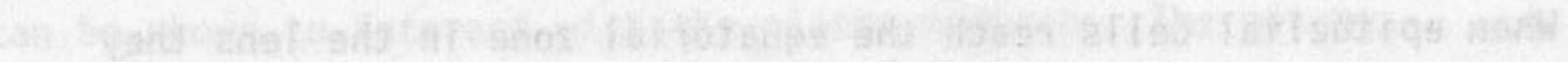

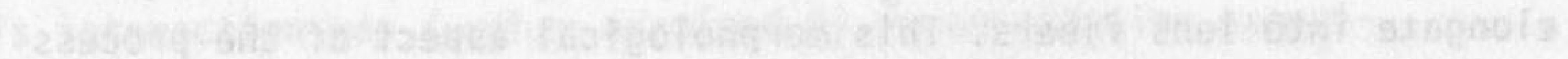

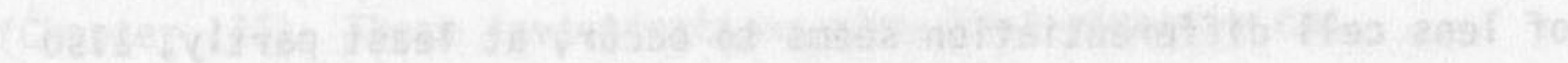

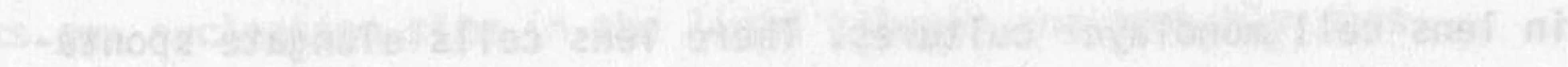

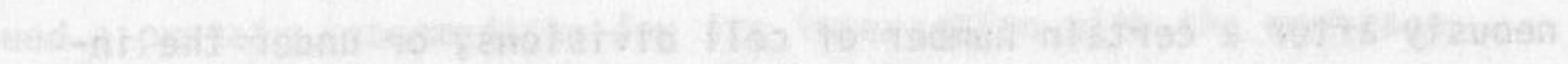

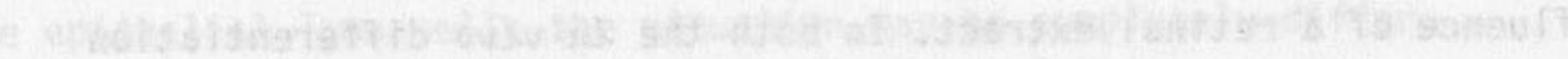

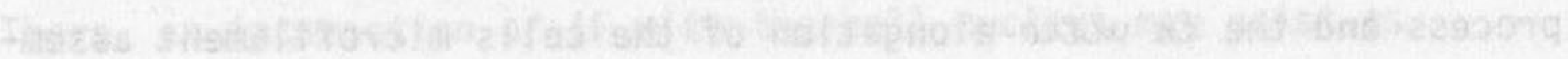

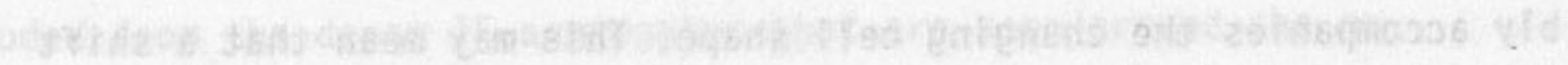

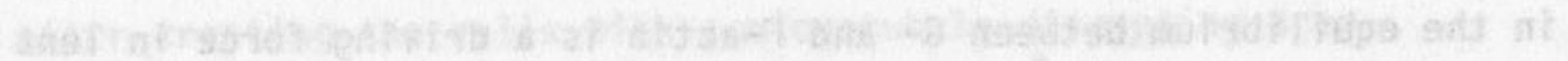

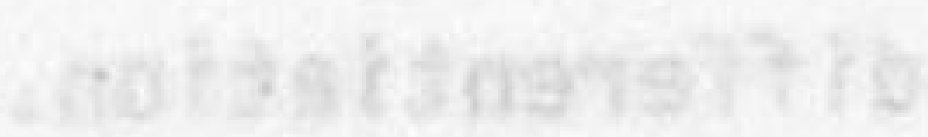

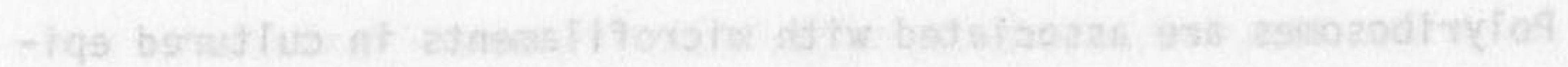

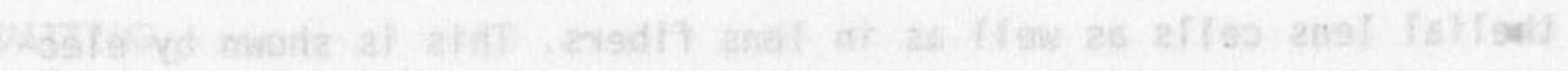

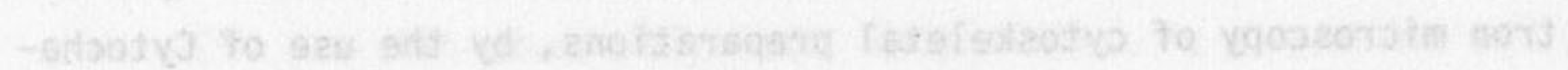

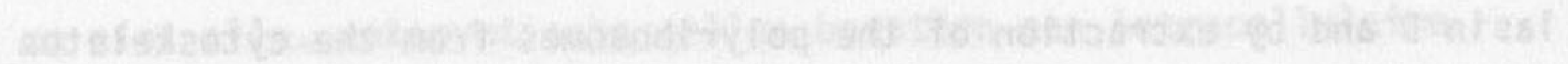

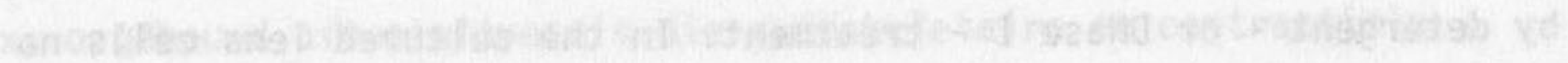

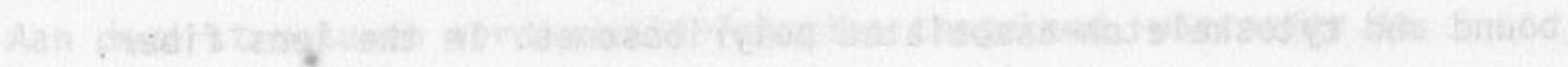
$-133-$ 
Many, if not all, eukaryotic cells contain an intracellular matrix built up of fibrillar elements called cytoskeletal and contractile structures (briefiy the cytoskeleton). The function of these structures is manyfold including cellular motility, a role in cell division, maintenance of cell shape and the realization of changes in cell shape.

The elements of the lenticular cytoskeleton can, like in other cells, be subdivided into three substructures: 1) microfilaments, containing actin. In cultured lens cells these filaments are associated with myosin, tropomyosin and $\alpha$-actinin and form thick bundles called stress fibers; 2) microtubules consisting of tubulin and 3) intermediate-sized filaments containing vimentin as their protein subunits.

Ad 1. Microfilaments. Functions of these actin filaments (F-actin) that are in equilibrium with their monomeric subunits (Gactin) have been described in Chapter IV-VII. A role in lens cell differentiation (elongation) and protein biosynthes is is suggested. When epithelial cells reach the equatorial zone in the lens they elongate into lens fibers. This morphological aspect of the process of lens cell differentiation seems to occur, at least partly, also in lens cell monolayer cultures. There lens cells elongate spontaneously after a certain number of cell divisions, or under the influence of a retinal extract. In both the in vivo differentiation process and the in vitro elongation of the cells microfilament assembly accompanies the changing cell shape. This may mean that a shift in the equilibrium between G- and F-actin is a driving force in lens differentiation.

Polyribosomes are associated with microfilaments in cultured epithelial lens cells as well as in lens fibers. This is shown by electron microscopy of cytoskeletal preparations, by the use of Cytochalasin $D$ and by extraction of the polyribosomes from the cytoskeleton by detergent - or DNase I - treatment. In the cultured lens cells no difference can be observed between the products of free, membranebound and cytoskeleton-associated polyribosomes. In the lens fiber, 
however, microfilament-associated polyribosomes direct the synthesis of the main intrinsic membrane protein MP26, which is a marker for lens differentiation. This protein is not synthesized by the 'free' lens polyribosomes, that synthesize the crystallins, the cytoskeletal proteins and the other membrane proteins.

Ad 2. Microtubules. In cultured lens cells in monolayers microtubules interact with intermediate-sized filaments as concluded from electron microscopy and the aggregation of the latter filaments after destruction of microtubules by Colcemid. This may suggest a cooperative role of both structures in mitosis and/or cell-shape maintenance.

Ad 3. Intermediate-sized filaments (IF). The nature of the protein subunit of these filaments is not typical for epithelial cells, since prekeratin has been shown to be the protein subunit of epithelial IF. Lens cells in culture and in the organ namely contain vimentin IF, typical for cells of mesenchymal origin. Whether this phenomenon reflects a special line of differentiation for lens cells is not clear at this moment (Chapter II).

By electron microscopy and biochemical techniques IF in lens fibers can be shown to interact with the plasma membrane. The nature of this interaction was further examined by reconstitution experiments (Chapter III). These investigations show that vimentin can form its own nucleation site in the lipid bilayer and probably does not need a protein intermediate for its interaction with the membrane. In the epithelial lens cells the situation may be completely different. There, an interaction of IF with the cell nucleus may exist as concluded from the dense IF aggregates that are seen around the nucleus after treating the cells with a microtubule-disrupting drug.

\section{SAMENVATTING}

Vele, zo niet alle, eukaryotische cellen bevatten een intracellulaire matrix, opgebouwd uit eiwitvezels die cytoskeletaire en contractiele structuren worden genoemd, of kortweg het cytoskelet.

Aan deze structuren worden vele functies toegekend, waaronder de 
beweging van cellen, een rol in de celdeling, het handhaven van de celvorm en het bewerkstelligen van veranderingen in de celvorm.

De bouwstenen van het cytoskelet van lenscellen kunnen, evenals in vele andere cellen, onderverdeeld worden in drie subeenheden: 1) microfilamenten, die opgebouwd zijn uit actine. In gekweekte lenscellen zijn deze vezels geassocieerd met myosine, tropomyosine en a-actinine en vormen zij dikke bundels die "stress fibers" worden genoemd; 2) microtubuli, opgebouwd uit tubuline en 3 ) intermediaire filamenten die vimentine als hun eiwit subeenheid bevatten.

Ad 1. Microfilamenten. De functies van de actinefilamenten (F-actine) die in evenwicht zijn met hun monomere vorm (G-actine) worden in de Hoofdstukken IV-VII beschreven. Een rol in lensceldifferentiatie (elongatie) en in de eiwitbiosynthese wordt voorgesteld. Wanneer de epitheliale cellen de lensequator bereiken, elongeren zij tot lensvezels. Dit morfologische aspect van lensdifferentiatie lijkt ook gedeeltelijk in lenscel-monolayer-kweken op te treden. In zo'n kweek elongeren de cellen spontaan na een aantal celdelingen of na toevoeging van een retina-extract. Zowel bij het in vivo differentiatieproces als bij de in vitro elongatie van de cellen gaat de verandering in de celvorm gepaard met een toename in de assemblage van microfilamenten. Dit betekent waarschijnlijk dat een verschuiving in het evenwicht tussen G- en F-actine een drijvende kracht vormt bij lensdifferentiatie.

Polyribosomen zijn geassocieerd met microfilamenten, zowel in gekweekte epitheliale lenscellen, als in de lensvezels. Dit kan worden aangetoond met behulp van electronenmicroscopie, door gebruik te maken van Cytochalasine $D$ en door middel van extractie van polysomen uit cytoskelet preparaten met detergentia of DNase I. Voor de gekweekte lenscellen kan geen verschil worden aangetoond tussen de produkten van de vrije, membraangebonden en cytoskelet-geassocieerde polyribosomen. In lensvezels echter synthetiseren de microfilament-geassocieerde polyribosomen het belangrijkste intrinsieke membraaneiwit MP26, dat als een marker voor lensdifferentiatie moet worden beschouwd. Dit eiwit wordt niet gemaakt door de "vrije" lenspolyribosomen, die de crystallines, de cytoskeletaire eiwitten en de andere membraaneiwitten synthetiseren. 
Ad 2. Microtubuli. In gekweekte lenscellen in monolayers gaan microtubuli en intermediaire filamenten interacties met elkaar aan. Dit is geconcludeerd op grond van electronen-microscopische waarnemingen en uit het feit dat de intermediaire filamenten aggregeren, nadat de microtubuli-structuur verstoord is met Colcemid. Dit suggereert een coöperatieve rol van beide structuren in de celdeling en/of bij het handhaven van de celvorm.

Ad 3. Intermediaire filamenten (IF). De aard van de eiwit-subeenheid van deze filamenten is niet typerend voor epitheliale cellen. zulkecellen bevatten namelijk prekeratine als IF-eiwit. Lenscellen in kweek en in het orgaan bevatten vimentine IF die typerend zijn voor cellen van mesenchymale oorsprong. Of dit fenomeen een speciale soort van differentiatie weerspiegelt voor lenscellen is op dit ogenblik nog niet duidelijk (Hoofdstuk II).

IF in lensvezels gaan een wisselwerking aan met de plasmamembraan, hetgeen biochemisch en met behulp van het electronmicroscoop aangetoond kan worden. De aard van deze interactie is verder bestudeerd in reconstitutie-experimenten (Hoofdstuk III). Deze studies tonen aan dat vimentine zijn eigen nucleatiecentrum in de lipide dubbellaag kan vormen en dus waarschijnlijk geen eiwit-intermediair nodig heeft voor zijn interactie met de membraan. In de epitheliale lenscellen kan de situatie volkomen verschillend zijn. In deze cellen bestaat waarschijnlijk een interactie van IF met de celkern. Dit kan worden geconcludeerd uit de dichte IF-aggregaten die rond de kern gevonden worden, wanneer de cel is behandeld met een agens dat de microtubulistructuur verstoort. 


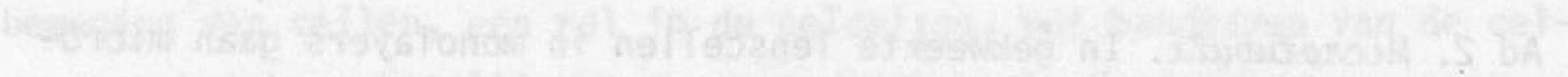

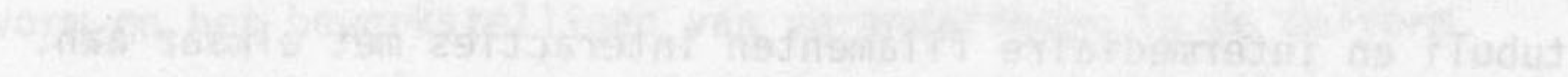

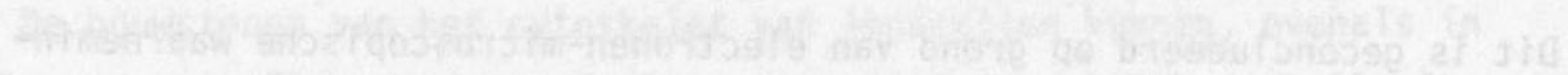

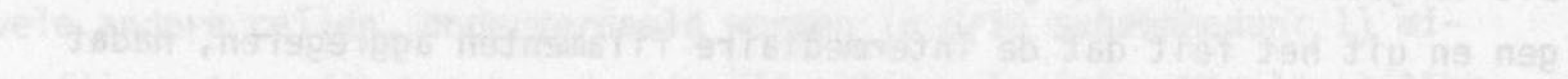

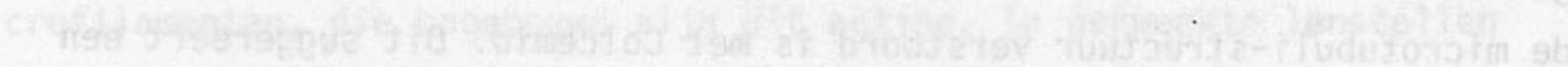

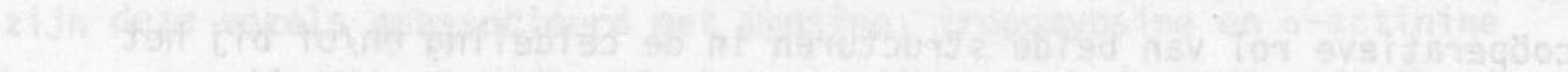

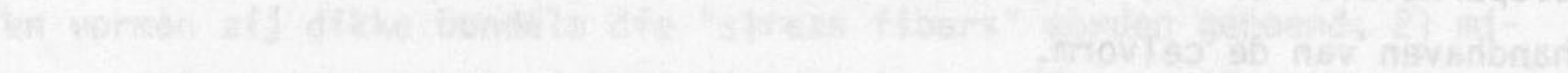

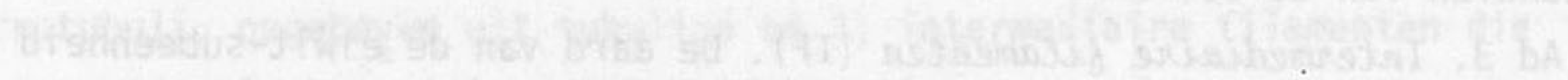

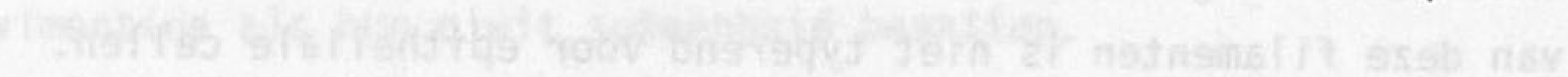

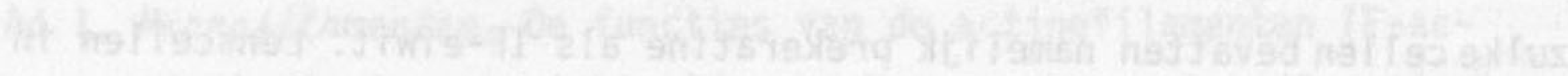

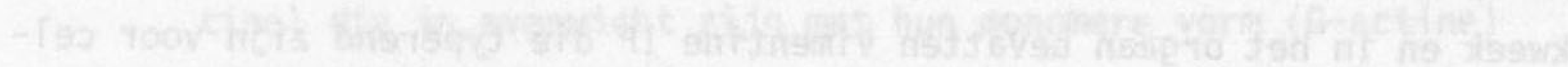

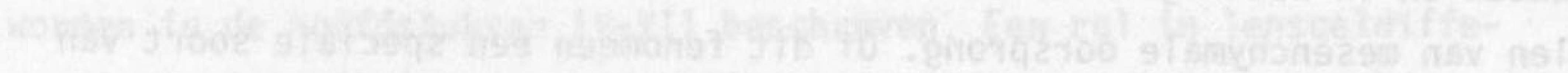

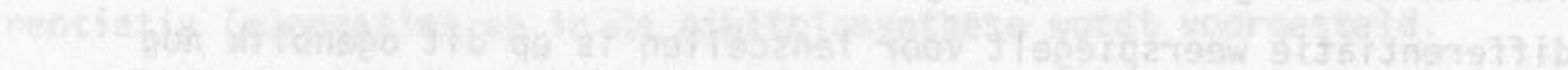

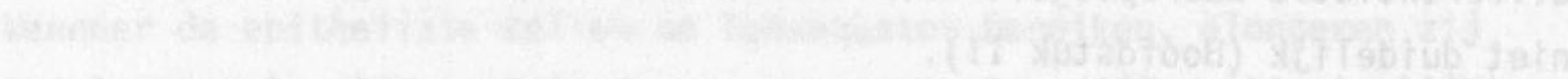

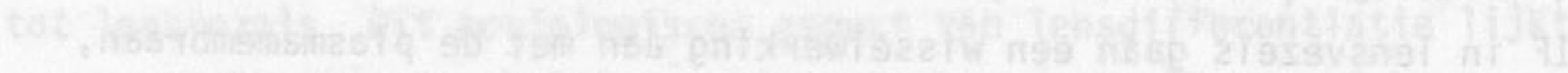

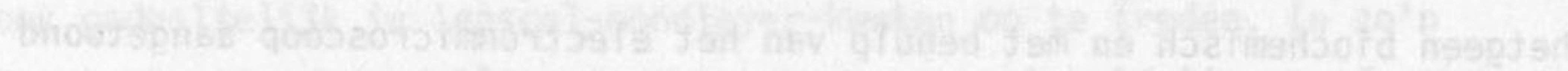

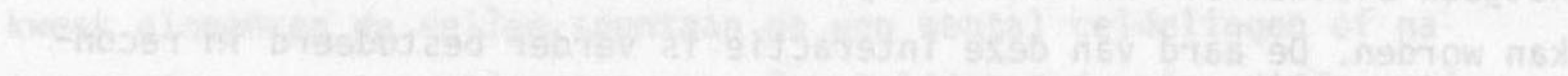

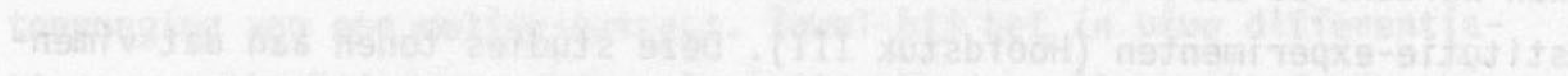

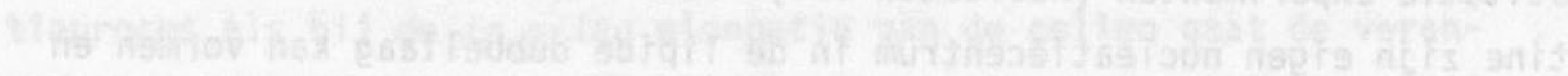
Whathit nd

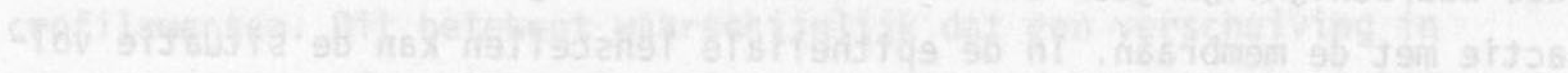

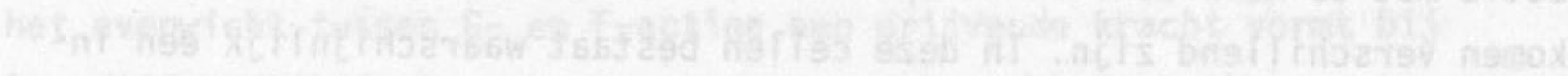

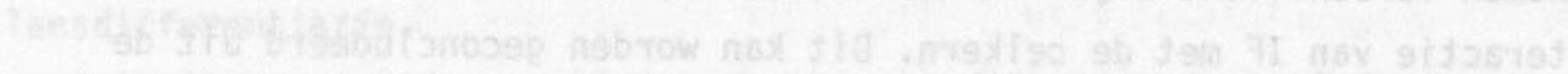

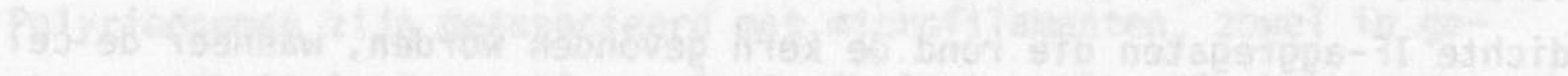

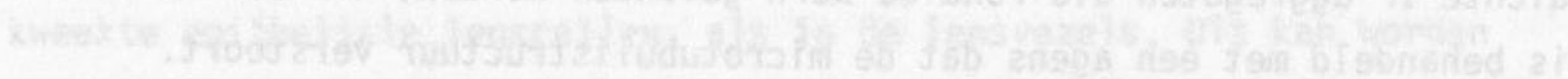

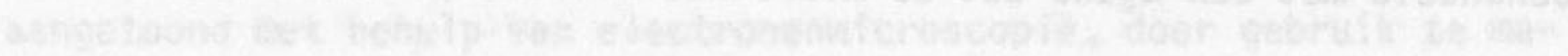

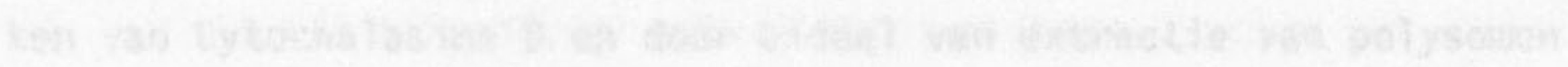

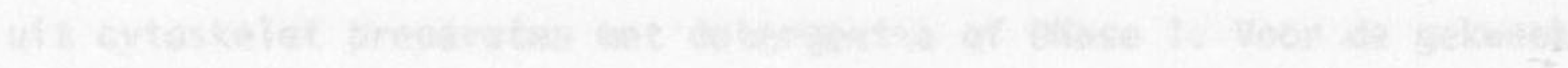

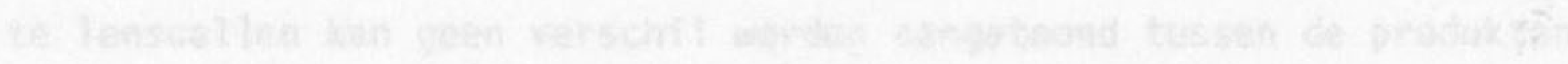

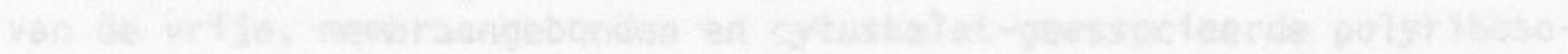

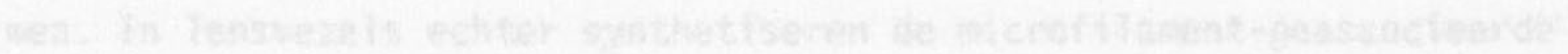

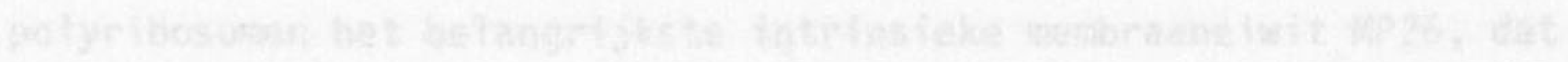

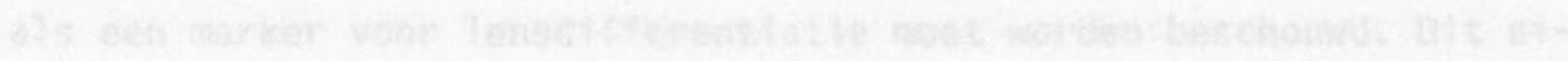

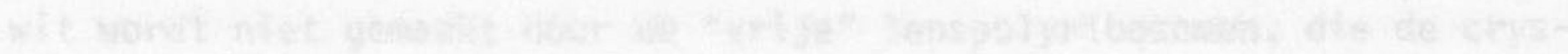

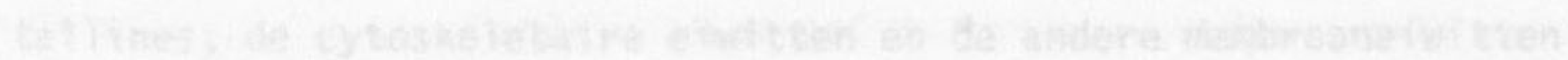

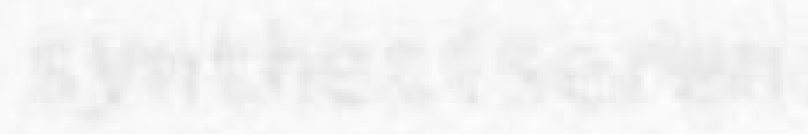


Frans Ramaekers werd op 3 juli 1952 te Schinveld geboren.

Zijn HBS-B opleiding volgde hij aan het St. Michiellyceum te Geleen waar in 1969 het diploma werd behaald. In hetzelfde jaar begon hij zijn studie Scheikunde aan de Katholieke Universiteit te Nijmegen.

Het kandidaatsexamen (S2) werd afgelegd in maart 1974. Het doctoraalexamen Scheikunde met als hoofdvakken Farmacochemie (Prof.dr. J.M. van Rossum; practische stage bij Organon BV te Oss) en Biochemie (Prof.dr. H. Bloemendal) werd afgelegd in januari 1977.

Vanaf februari 1977 tot februari 1981 is hij als wetenschappelijk medewerker in dienst van de Nederlandse Organisatie voor Zuiver Wetenschappelijk Onderzoek (Stichting SON, Werkgemeenschap Nucleīnezuren) verbonden geweest aan het Laboratorium voor Biochemie (Hoofd: Prof.dr. H. Bloemendal) van de Katholieke Universiteit te Nijmegen. In die periode werd het hier beschreven promotie-onderzoek verricht en leverde hij een bijdrage in het onderwijs aan medicijnen- en scheikundestudenten.

In september 1977 is hij getrouwd met Tineke Kloppenberg.

In juni 1980 werd hun zoon Giel geboren.

Sinds 1 februari 1981 is hij in dienst van het Koningin Wilhelmina Fonds en verricht als wetenschappelijk medewerker onderzoek aan cytoskeletaire structuren in tumorcellen op de afdeling Pathologische Anatomie (Hoofd: Prof.dr. G.P. Vooijs) van het St. Radboud Ziekenhuis te Nijmegen. 


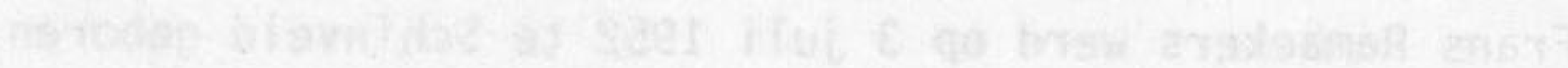

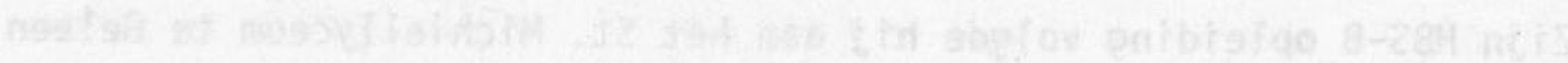

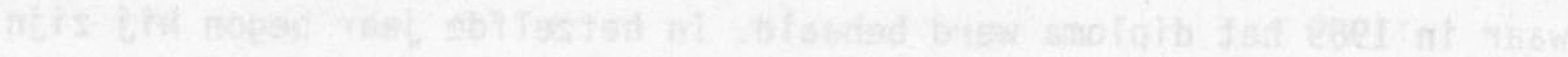

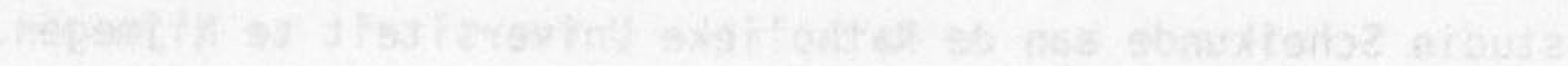

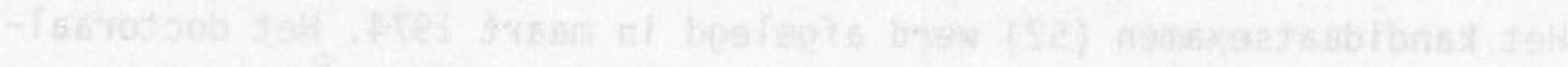

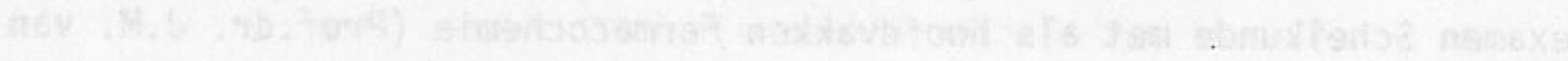

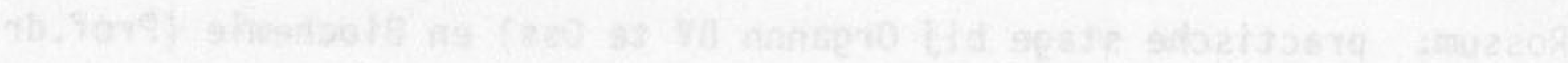

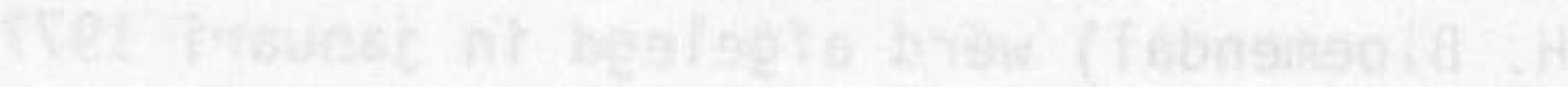

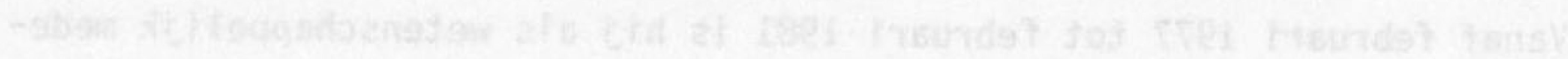

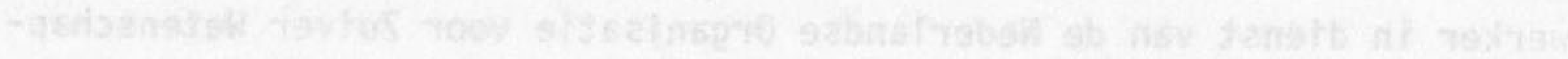

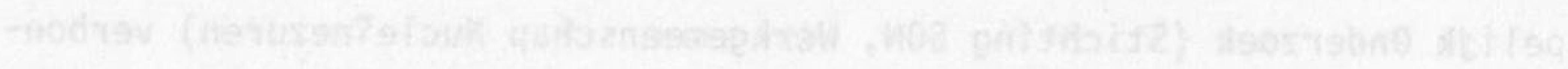

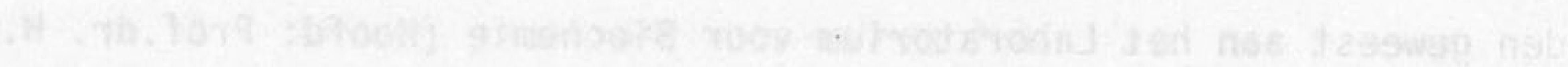

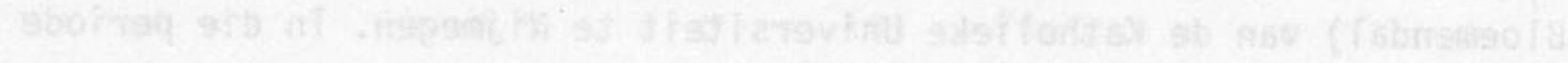

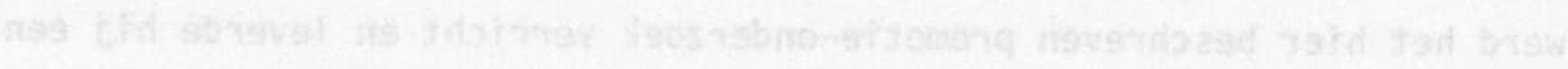

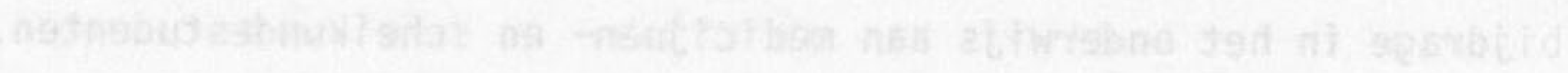

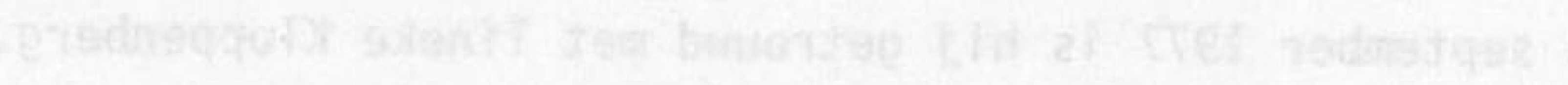

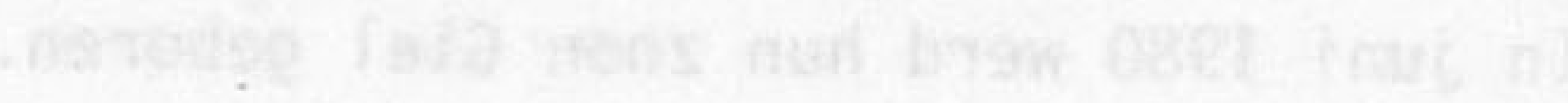

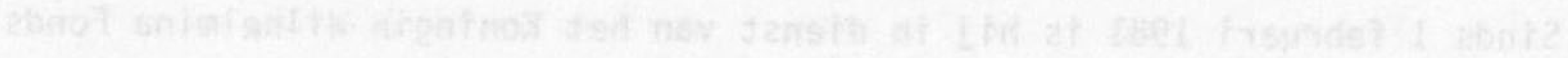

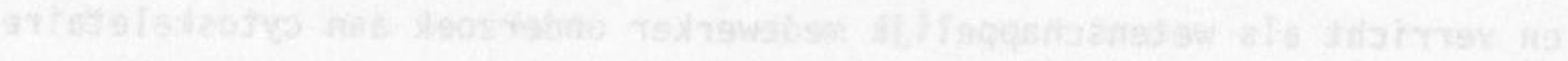

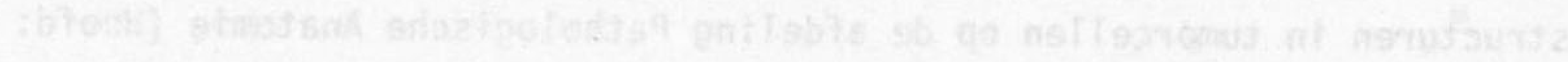

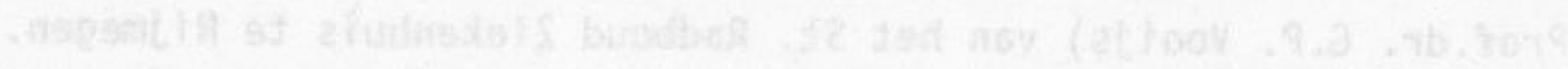


STELLINGEN

I

Ondanks de onoplosbaarheid van vimentine onder fysiologische omstandigheden kan met behulp van labelingstudies worden aangetoond dat het nieuw gesynthetiseerde eiwit als trimeer in oplosbare vorm in het cytoplasma van de cel aanwezig is.

Dit proefschrift, pag 58.

Bij het aantonen van weefselspecificiteit van intermediaire-filamenteiwitten dient rekening gehouden te worden met het embryonale stadium, waarin de cellen zich bevinden.

Blose, S.H., Shelanski, M.L., Chacko, S. (1977) Proc. Natl. Acad. Sci. USA 74, 662 en Gard, D.L., Bell, P.B., Lazarides, E. (1979) Proc. Natl. Acad. Sci. USA, 76, 3894.

De "mutatiesnelheid" door het onzorgvuldig overnemen van DNA-sequenties is hoger dan de werkelijke evolutiesnelheid.

Nishioka, Y., Leder, P. (1979) Cell 18, 875 en Efstratiadis, A., Posakony, J.w., Maniatis, T., Lawn, R.M., O'Connell, C.O., Spritz, R.A., DeRiel, J.K., Forget, B.G., weissman, S.M., Slightom, J.L., Blechl, A.E., Smithies, O., Baralle, F.E., Shoulders, C.C., Proudfoot, J. (1980) Cell 21, 653.

IV

Bij het huidige niveau van diagnostiek zijn er geen argumenten die een bevolkingsonderzoek op longcarcinoom rechtvaardigen.

V

De conclusies van Cocco et al. over de rol die fosfolipiden bij de binding van nucleinezuren aan de kernmatrix spelen, zijn aanvechtbaar.

Cocco, L., Maraldi, N.M., Manzoli, F.A., Gilmour, R.S., Lang, A. (1980)

Biochem. Biophys. Res. Comm. 96, 890. 
Er zou moeten worden gestreefd naar een routinematige invoering van kwantitatief morfologische technieken in de pathologisch anatomische diagnostiek.

\section{VII}

De uitgave van een, door de (provinciale) overheid gesubsidieerd, samenhangend geschiedkundig overzicht van de gebieden die het huidige Limburg vormen, is zeer wenselijk. Een dergelijke uitgave zou er tevens toe moeten bijdragen dat de feiten, verzameld door zowel professionele historici als door de locale amateurhistorici, gecombineerd en op elkaar afgestemd worden.

Nijmegen, 7 mei 1981

F.C.S. Ramaekers 
Met behulp van de immuunfluorescentie-techniek is aangetoond dat de samenstelling van de intermediaire filamenten specifiek is voor bepalde weefseltypen. Daardoor zijn wij nu in staat die weefsels, maar ook de tumoren ontstaan uit deze weefsels op deze manier te herkennen. De techniek zal daarom worden toegepast bij de identificatie van moeilijk te karakteriseren gezwellen.

De functie van het cytoskelet in de cel is meervoudig. Zoals de naam al enigszins aanduidt, is één van de functies het instandhouden van de celvorm en van de verdeling van andere organellen in de cel. Dus, zoals het menselijke skelet onze lichaamsvorm bepaalt, zo bepaalt het cytoskelet de celvorm. Daarnaast echter zorgen deze structuren ook voor de veranderingen die optreden in de celvorm. Bijvoorbeeld, wanneer een cel deelt, zijn bij de bewegingen en samentrekkingen (contracties) die optreden, de cytoskeletvezels betrokken. De rol van het cytoskelet bij de vormverandering van lenscellen wordt in de Hoofdstukken IV en $V$ besproken.

In de twee laatste hoofdstukken komt een functie van het cytoskelet ter sprake die in eerste instantie niet zozeer voor de hand ligt. Het blijkt namelijk dat de aanmaak van bepaalde nieuwe eiwitten op het cytoskelet gebeurt. Op deze manier is de cel in staat eiwitten precies op die plaats te produceren waar ze nodig zijn.

Hoewel in de afgelopen jaren de wetenschappelijke belangstelling voor het cytoskelet is gegroeid, zullen toch nog vele vragen over de betekenis van deze structuren in de cel moeten worden beantwoord. 
TOELICHTING bij het proefschrift "Cytoskeletal and contractile structures in lens cells" van F.C.S. Ramaekers

Deze toelichting dient om de achtergrond en inhoud van dit proefschrift voor niet-ingewijden enigszins te verduidelijken.

Ik zal in het kort proberen uit te leggen wat "cytoskeletaire en contractiele structuren", kortweg het cytoskelet, zijn en welke functies ze mogelijk in de cel vervullen.

Het feit dat voor dit onderzoek de lens is gebruikt, wil niet zeggen dat de verkregen gegevens alleen toepasbaar zouden zijn op dit orgaan. Zeer vele, hoogstwaarschijnlijk alle, cellen in ons lichaam bevatten namelijk zo'n cytoskelet. De hier beschreven resultaten kunnen dus ook van belang zijn bij de bestudering van het cytoskelet in andere weefsels.

Hoe ziet zo'n cytoskelet er uit?

Wanneer we met de electronenmicroscoop een blik in de cel werpen, zien we dat het cytoskelet is opgebouwd uit lange, flexibele en minder flexibele, eiwitvezels, die de hele cel doorkruisen. Deze eiwitvezels kunnen aan de hand van hun dikte en samenstelling onderverdeeld worden in drie groepen. De dunste vezels (filamenten) heten microfilamenten, terwijl de dikste vezels microtubuli (holle buizen) worden genoemd. Vezels, waarvan de dikte tussen die van de microfilamenten en microtubuli inligt, noemen wij intermediaire filamenten.

De samenstelling van de vezels kan met biochemische technieken achterhaald worden. In de Hoofdstukken II en III is een overzicht van de samenstelling van de vezels in lenscellen beschreven. De structuur ervan kan niet alleen zichtbaar worden gemaakt met de electronenmicroscoop, maar ook met de indirekte immuunfluorescentie-techniek. In deze laats te methode wordt gebruik gemaakt van antilichamen die gericht zijn tegen de verschillende eiwitten van het cytoskelet. Deze antilichamen binden dan weer aandie eiwitten in de cel waartegen ze gericht zijn. Als de antilichamen ook nog gemerkt worden, kunnen de verschillende vezelvormen apart zichtbaar gemaakt worden. De ontwikkeling van deze laatste methode heeft de ontdekking van de cytoskeletvezels grotendeels mogelijk gemaakt. De aanwezigheid en de aard van de vezels in de cel is dan ook nog niet zo lang bekend en de mogelijkheid dat er nog onbekende vezelstructuren in de cel voorkomen, kan niet worden uitgesloten. 